\title{
Ammonites from the Maastrichtian White Chalk of Denmark
}

\author{
TOVE BIRKELUND
}

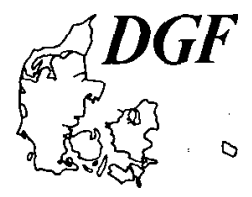

Birkelund, T.: Ammonites from the Maastrichtian White Chalk of Denmark. Bull. geol. Soc. Denmark, vol. 40, pp. 33-81, Copenhagen, June 3th, 1993. https://doi.org/10.37570/bgsd-1994-40-02

Nineteen ammonite species are described or recorded from the Maastrichtian White Chalk of Denmark: Hypophylloceras (Neophylloceras) surya (Forbes, 1846), H. (N.) velledaeforme (Schlüter, 1872), Anagaudryceras luenebergense (Schlüter, 1872), Saghalinites wrighti Birkelund, 1965, Saghalinites n. sp., Pachydiscus (Pachydiscus) neubergicus (Hauer, 1858), Anapachydiscus aff. fresvillensis (Seunes, 1890), Glyptoxoceras cf. tenuisulcatum(Forbes, 1846), Diplomoceras cylindraceum (Defrance, 1816), P. (Phylloptychoceras) sp., Baculites knorrianus Desmarest, 1817, B. vertebralis Lamarck, 1801, Baculites species 1, 2 and 3, Acanthoscaphites tridens (Kner, 1848), A. varians (Lopuski, 1911), Hoploscaphites constrictus (J. Sowerby, 1817) and $H$. tenuistriatus (Kner, 1848), and their ranges documented in terms of existing brachiopod and belemnite zonations. Seven taxa, representing the Phylloceratina, Lytoceratina, Ammonitina and Ancyloceratina, extend to the high Maastrichtian at Stevns Klint. There are no indigenous Danian ammonites; specimens found in the basal Danian are derived from the underlying Maastrichtian.

June 20th, 1990.

\section{Preface}

Professor Tove Birkelund died on June 24th 1986, entrusting me to complete for publication her revision of the ammonites from the Maastrichtian White Chalk of Denmark, a topic which had occupied her for many years. The preliminary results were published in volume 1 of the Proceedings of the Cretaceous-Tertiary Boundary Events Symposium held in Copenhagen in 1979 (Birkelund, 1979). Her manuscript consisted of the systematics of Hypophylloceras, Anagaudryceras, Saghalinites, Pachydiscus, Anapachydiscus, Dipolomoceras Phylloptychoceras and Acanthoscaphites. These I have revised to take account of recent publications, and added systematic accounts of Baculites and Hoploscaphites, based on her 1979 publication, and our subsequent discussions on these taxa. To these I have added a series of introductory sections based upon the same publication, and subsequent discussions, notably on the occurrence of the last Maastrichtian ammonites from the Danish chalk, and those that occur reworked into the succeeding Danian.

I thank Professor J. H. Callomon (University College, London), Dr. C. W. Wright (Seaborough), Dr. W. K. Christensen, Dr. H. J. Hansen and Dr. F. Surlyk (Copenhagen) for their advice and assistance in this task, and acknowledge, with thanks, the financial support of the Natural Environment Research Council (UK) and Danish Natural Science Research Council. Photographs are by Jan Aagaard and myself.

W. J. Kennedy, Geological Collections, University Museum, Parks Road, Oxford OX1 3PW, Great Britain.

\section{Introduction}

Ravn (1903) provides a detailed account of nineteenth century studies of the faunas of the Danish Chalk. The only significant work dealing with ammonites is that of Schlüter (1871-1876), who described (1876, p. 161, pl. 42, fig. 6) as Ammonites sp.n., a silicified specimen from Ålborg that was subsequently referred to Saghalinites wrighti Birkelund, 1965 (Pl. 1, figs. 6, 7), and noted the presence of Ammonites luenebergensis Schlüter, 1872, from the Island of Rügen, now in the German Federal Republic (Schlüter, 1876). Schlüter also recorded Scaphites constrictus, $S$. cf. tridens, Hamites cf. cylindraceus and Baculites cf. knorrianus from from Denmark and Rügen, these six species totalling those known from the "baltische Schreibekreide" (1876, p. 249). Ravn (1902) described "Phylloceras velledaeforme Schlüter sp., 


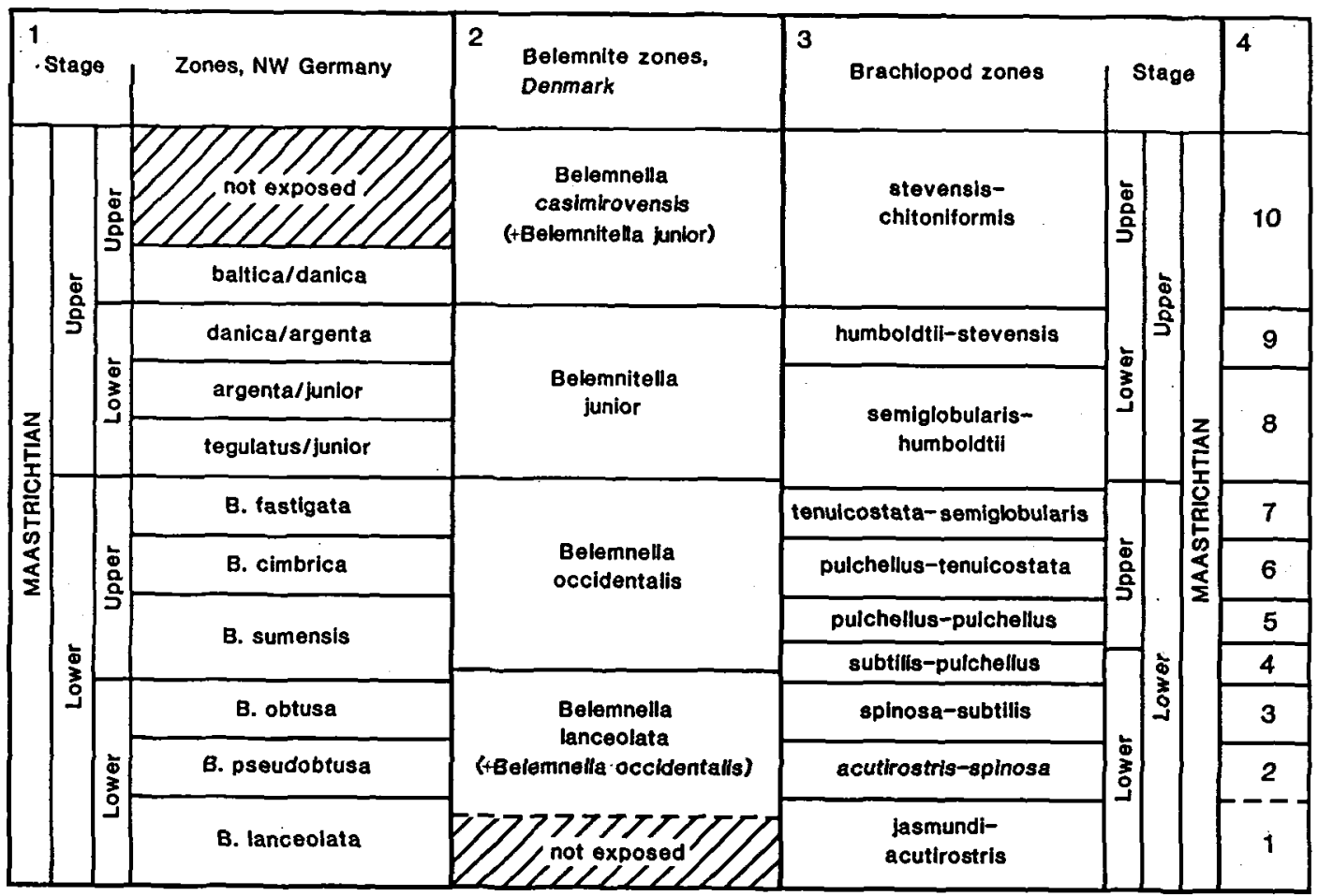

Text-fig. 1. Belemnite and microbrachiopod zonations for the Maastrichtian White Chalk in Denmark and north Germany prepared by Dr. W. K. Christensen. Sources are as follows: Column 1: Schulz (1979) and Schulz and Schmid (1983). Column 2: Birkelund (1957) and Christensen $(1979,1988)$. Column 3: Surlyk (1984). Column 4: Surlyk (1970). Note that Surlyk placed the boundary between the lower and upper Lower Maastrichtian between the spinosa-subtilis and subtilis-pulchellus zone in 1982, and within the topmost subtilis-pulchellus zone in 1984.

Hamites cylindraceus Defrance sp., Baculites vertebralis Lamarck, Baculites Valognensis Joh. Böhm, Baculites Knorrianus Desmarest, Desmoceras Lünebergense Schlüter sp., Scaphites constrictus Sowerby sp., Scaphites Römeri d'Orbigny, Scaphites tridens Kner?, and Ammonites n.sp.? Schlüter" from the "skrivekridt", and this remained the only account of the ammonite fauna until Birkelund (1979, pp. 51-57) gave the ranges of 21 species or subspecies of ammonites, provided notes on six species and four genera, and discussed the fauna of the topmost Maastrichtian at Stevns Klint.

Ammonites are generally rare in the White Chalk facies of Denmark, and indeed elsewhere. In soft chalks they occur as composite moulds (e.g. PIs. 2-12), with, exceptionally, silicified specimens (Pl. 1, figs. 1, 6, 7). The former are invariably distorted, the latter may lack surface detail. Better preservation is to be found in the hardground facies, for these levels of early submarine cementation may preserve undeformed external plus internal moulds (Birkelund, 1979, text-fig. 3) that show the very earliest developmental stages (e.g. Pl. 13, figs. 1-11; Pl. 17, figs. 6-9, 11-23; Textfigures 5, 6).

In spite of their scarcity and frequently poor preservation the ammonites of the Danish White Chalk are of great scientific interest, for they provide the best precisely dated records and ranges for the whole of the Maastrichtian in the Boreal Realm of north-west Europe. Faunas from Lüneberg (Schlüter, 1871-1876), and Hemmoor, Niederelbe, in the German Federal Republic (Birkelund, 1982), the environs of Maastricht in The Netherlands and Belgium (Kennedy, 1986a, 1987) and the Calcaire à Baculites of the Cotentin Peninsula, Manche, France (Kennedy, 1986b) are better preserved, but are of much more limited stratigraphic range. The present material thus provides the best evidence for the decline and final demise of ammonites in the Chalk Sea of north-west Europe.

As Birkelund (1979, p. 51) notes, much of the 


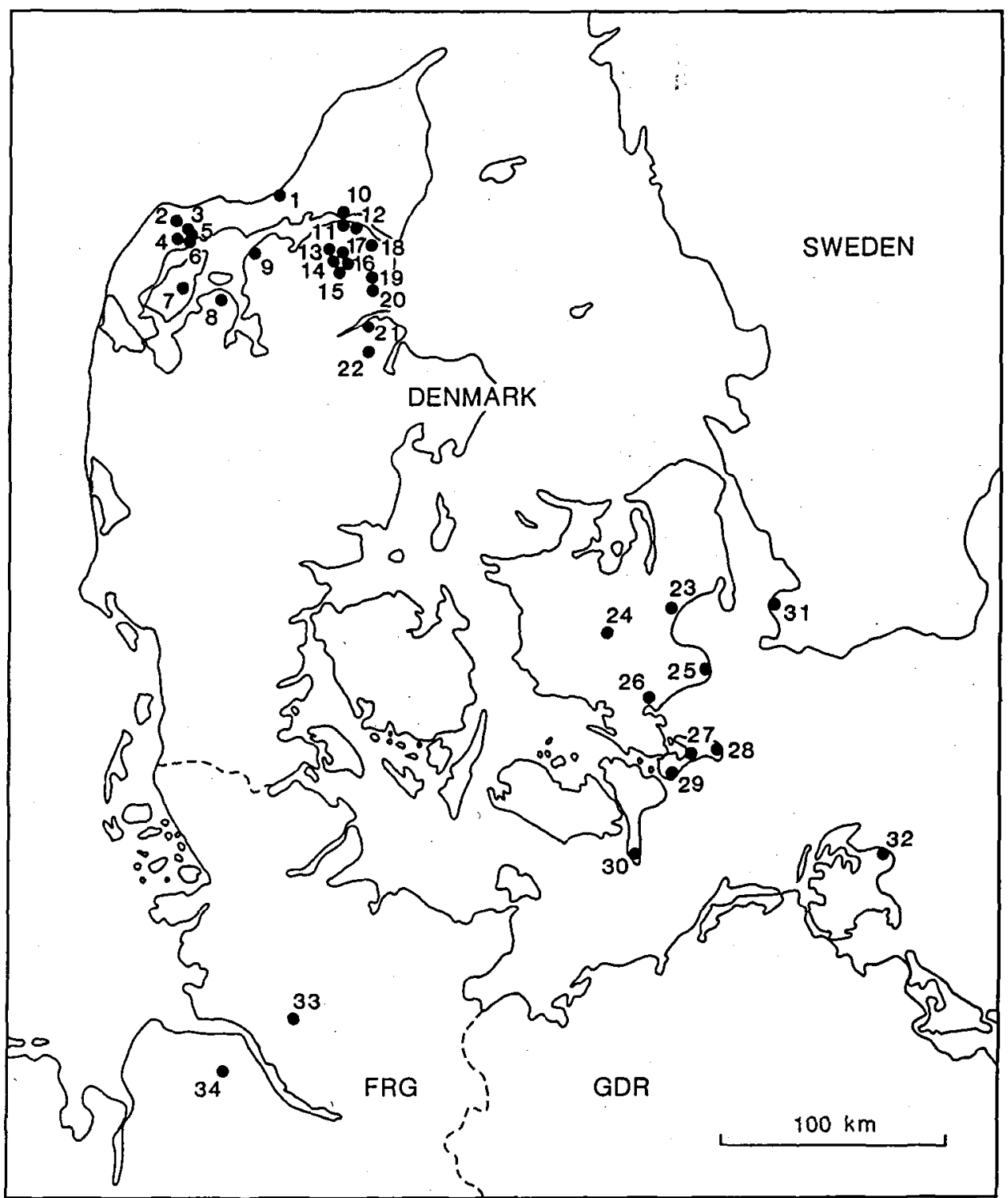

Text-fig. 2. Sketch map showing localities mentioned in the text, redrawn from Surlyk (1984). 1. Svinkløv, 2. Bjerre. 3. Kjølby Gård, 4. Hillerslev, 5. Nye Kløv, 6. Hov, 7. Eerslev, 8. Batum, 9. Aggersund, 10. Lindholm. 11. "Danmark", 12. Rørdal, 13. Nørre Flødal, 14. "Linds Kalkværk", 15. Ellidshøj, 16. Mjels, 17, Ferslev, 18. Gudumholm, 19. Sønder Kongerslev. 20. Smidie. 21. "Dania", 22. Spentrup, 23, Karlstrup, 24. Allindelille, 25. Stevns Klint. 26. Kongsted, 27. Lille Bissinge, 28. Møns Klint (Jættebrink, Hundefangsklint. Hvidskud, Lille Stejlebjerg, Store Stejlebjerg, Gråryg, Nellerendenakke, Sommerspir, Sandpynt, Maglevandspynt, Forchhammers Pynt, Vitmunds Nakke, Nylands Nakke, Sattepileklint, Store Taler, Lille Taler, Slotsgavlene), 29. Hvide Klint, 30. Gedser Fyr and Gedser Odde, 31, Limhamn, 32. Rügen, 33. Kronsmoor, 34. Hemmoor.

present material has the drawback that it was collected without associated bulk-sampling of sediment, or is drawn from old museum collections. As a result, it cannot all be placed in the detailed microbrachiopod and belemnite zones currently in use. In spite of this, the associated stratigraphic data is still better than that for other areas in NW Europe. 


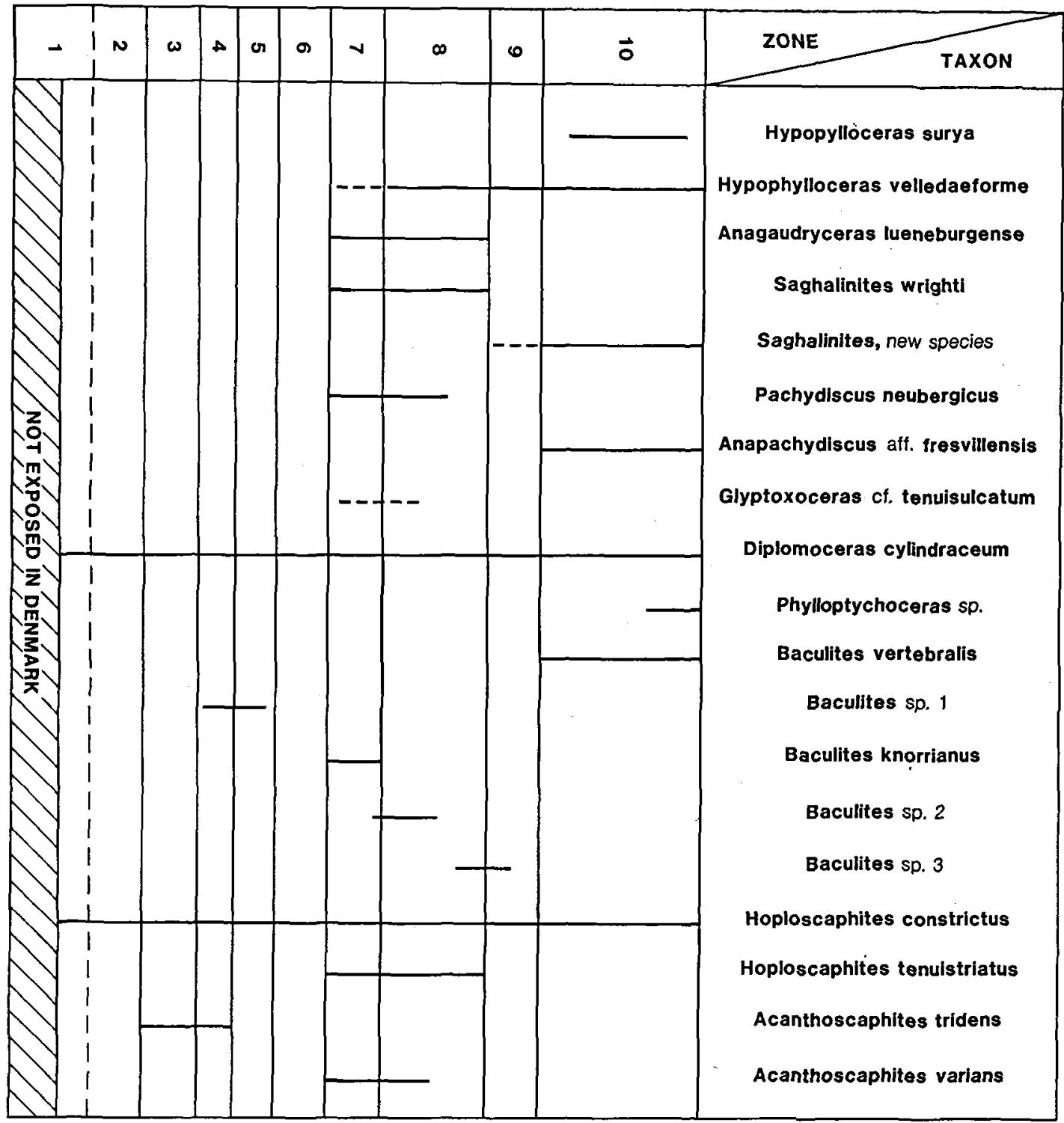

Text-fig. 3. Stratigraphic distribution of ammonites in the Danish Maastrichtian. Numbers in the zonal scheme refer to brachiopod zones shown in Text-fig. 2 .

\section{Biostratigraphy}

No usable ammonite zonation exists for the Maastrichtian in the White Chalk facies of NW Europe. Instead, two other groups, belemnites and microbrachiopods, are used. The latter zonation, based on the scheme of Surlyk $(1972,1979 a$, 1982, 1984), is used here. Text-figure 1 shows this scheme and its correlation with the belemnite zones of the Danish Maastrichtian used by Birkelund (1957) and Christensen $(1979,1988)$ and the more detailed north German scheme of Schulz (1979).

Localities mentioned in the text are shown in Text-figure 2. Descriptions of the more important localities are given in Birkelund \& Bromley (1979). 


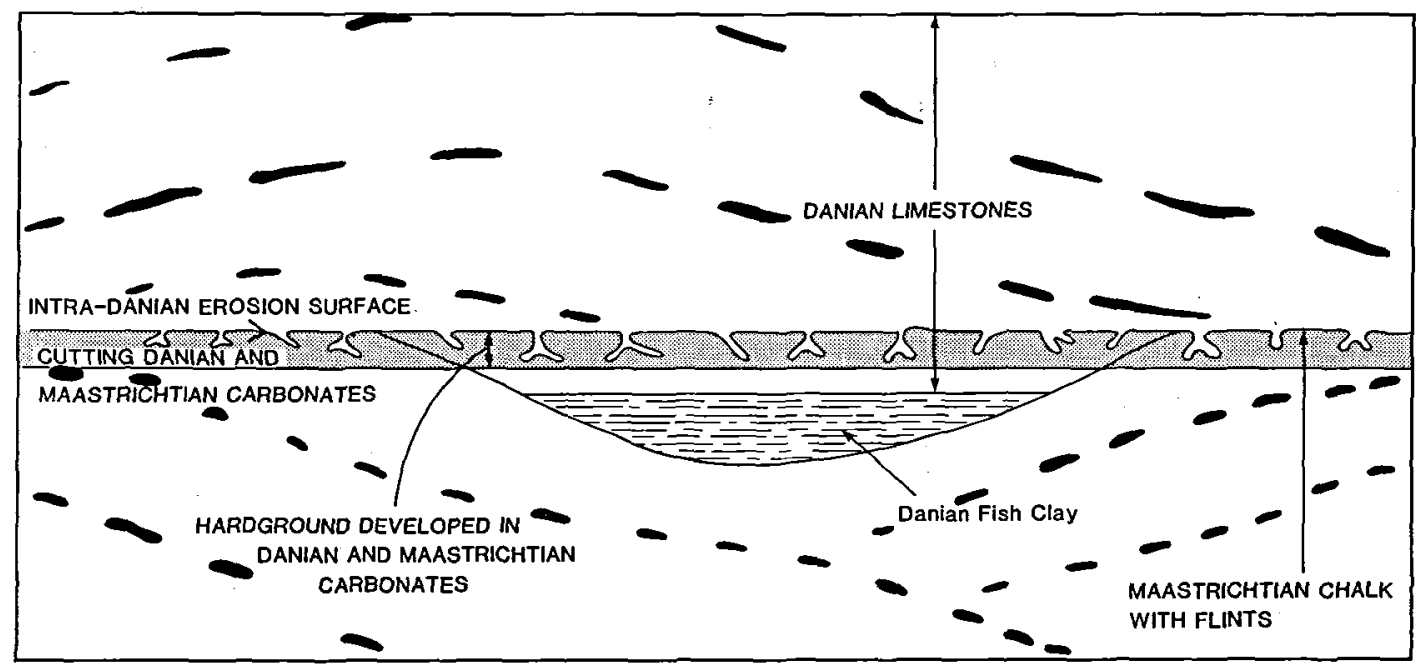

F Flint bands Fish Clay $\quad 25$ Thalassinoides Hardground

Text-fig. 4. Schematic representation of the Maastrichtian/Danian boundary at Stevns Klint: see text for discussion.

\section{Stratigraphic distribution of the ammonites}

Text-figure 3 shows the known stratigraphic range of the ammonites from the Danish White Chalk, plotted against the brachiopod zonation shown in Text-figure 1. Material is never abundant in most cases and these are undoubtedly only partial range zones (e.g. Phylloptychoceras sp., Acanthoscaphites tridens). These ranges are compared with known occurrences elsewhere at the appropriate point in the systematic section.

The last Maastrichtian ammonites in the Danish White Chalk

The occurrence of ammonites in relation to the base of the Danian is documented at two localities: Kjølby Gård (4 in Text-figure 2) and Stevns Klint (26 in Text-figure 2).

At Kjølby Gård (Håkansson \& Hansen, 1979), the Maastrichtian-Danian succession is in a pelagic chalk facies. Hoploscaphites constrictus and Baculites vertebratis have been collected to within $20 \mathrm{~cm}$ of the base of the Danian.

A more extensive fauna occurs at Stevns Klint, but here the succession across the boundary is lithologically, sedimentologically and diagenetically complex. The sequence was deciphered by Rosenkrantz (1924, 1966), and a more recent account is given by Surlyk (1979b), who reviews previous literature. His description is repeated below, while Text-figure 4 summarises relationships at the boundary in schematic form.

\section{The Maastrichtian sequence}

The Maastrichtian is represented by different subfacies of chalk and a total thickness of $c .35 \mathrm{~m}$ is exposed along the cliff. The lowest $5-10 \mathrm{~m}$ of the exposed sequence comprise white chalk with a large content of bryozoans. The chalk was deposited as low mounds revealed most notably by the undulating course of the flint bands. Some of the mounds show a slight overlap. The level with mounds is followed upwards by about $20 \mathrm{~m}$ of horizontally bedded chalk with scattered flint nodules and a lower fossil content. This unit is characterized by a high density of Zoophycos burrows. A prominent nodular flint layer occurs about 3-4 $\mathrm{m}$ below the Maastrichtian-Danian boundary. This layer can be traced almost along the whole length of the cliff. Along the main part of the cliff the flint layer is followed by one and locally two omission surfaces topping weakly lithified chalk. These surfaces are outlined by a yellowish rusty colour and form the top of the normal soft white chalk. The highest of the incipient hardgrounds locally underwent small-scale overthrusting reminiscent of teepee structures.

The upper surface forms the base for a se- 
quence of grey chalk $2.5-3.5 \mathrm{~m}$ thick showing a very high content (up to $20 \%$ ) of small benthic fossils, notably bryozoans. The grey colour was ascribed to presence of elementary carbon by Hansen et al. (1987). The grey chalk was deposited as low asymmetric, biohermal ridges or mounds each of which overlap the next ridge to the south. The southern flank is steepest and shortest and strong flint bands are only found within the less steep northern flank. The bioherms are characterized by Thalassinoides, the fill of which is sometimes burrowed by Chondrites. The highest density of recognizably Thalassinoides occur in $50 \mathrm{~cm}$ thick bands which dip to the north parallel to the surface of the bioherms. Synsedimentary slumping and slurry flows were characteristic processes on the flanks. The flows were normally of a rather small size incorporating masses of chalk at maximum a few tens of centimetres thick and 1-2 metres long. The growth of the bioherms can probably be explained by the model proposed by Thomsen $(1976,1977)$ for Danian bryozoan bioherms. According to Thomsen the mounds grew under influence of unidirectional currents which promoted growth in an upcurrent direction. The Maastrichtian bioherms are altogether richer in matrix than their Danian analogues and the sediment can be classified as a bryozoan wackestone all through the mound structures (Svendsen, 1975). They can probably be considered a slightly deeper water, early stage of the more impressive and more benthos rich Danian mounds.

\section{The Danian sequence}

Maastrichtian carbonates are abruptly overlain by a dark marl band, the so-called Fish Clay constituting the basal Danian bed. It occurs in the low basins between the summits of the Maastrichtian bryozoan bioherms and reaches $3-4 \mathrm{~cm}$ but at one place a thickness of $20-35 \mathrm{~cm}$ in the deepest parts of the basins. It wedges out completely towards the margins of the basins. The Fish clay has been studied in some detail by Christensen et al. (1973) who distinguished 4 beds, beginning with 1) a grey laminated marl, followed by 2) black marl with pyrite concretions, which again is overlain by 3 ) black laminated marl. This gives way to 4) light-grey marl with flattened lenses of white chalk, which gradually passes into the indurated Cerithium limestone. The fine, undisturbed lamination of especially bed 3 ) and the abundant occurrence of pyrite concretions suggest euxinic conditions during deposition of the lower part of the Fish clay. The lamination was later shown to be composed of compacted, partly filled burrows. The pyrite concretions were found to be of late diagenetic origin (Hansen et al. 1988). The provenance of the bed seems to be in part terrigenous (quartz and feldspar) in part authigene (mixed-layer clay minerals).

The Fish clay contains relatively few fossils such as fish scales and teeth, which have given name to the unit. Reworked late Maastrichtian fossils are quite abundant and the coccolith assemblage consists of reworked Upper Maastrichtian forms $(99 \%)$ and only very few indigenous species characteristic for the lowest Tertiary nannoplankton zone (NP1) (K. Perch-Nielsen, pers. comm., 1979).

The Fish clay gives way with a gradual transition to the hard yellow Cerithium limestone. The latter is penetrated by innumerably Thalassinoides burrows and microfaults with slickensides. The next stage was characterized by erosion of the top part of the Cerithium limestone and the intervening crests of the Maastrichtian bioherms. In this way a horizontal erosion surface was developed which cuts alternately through the highest Maastrichtian bryozoan chalk and the lower Danian Cerithium limestone. This process was probably a submarine dissolution (Hansen 1990) and was followed by early diagenetic submarine cementation down to a depth of about $30 \mathrm{~cm}$. The Thalassinoides burrows comprise both pre-omission and omission suites. The latter are deformed by concurrent activity of the burrowing infauna and the lithification processes (Bromley, 1967, 1975).

The planar erosion surface cuts through the remains of horizontal burrow networks destroying the upper half. Some of these burrows reach a diameter of $12 \mathrm{~cm}$ (Bromley, 1968). The fill of the burrows mainly comprises the delicate skeletons of Danian bryozoans and often shows some degree of silicification. To the south are seen all stages from grey, porous chalcedonic flint to solid, black flint. These variations can occur even within one burrow (Surlyk, 1969). The burrow 

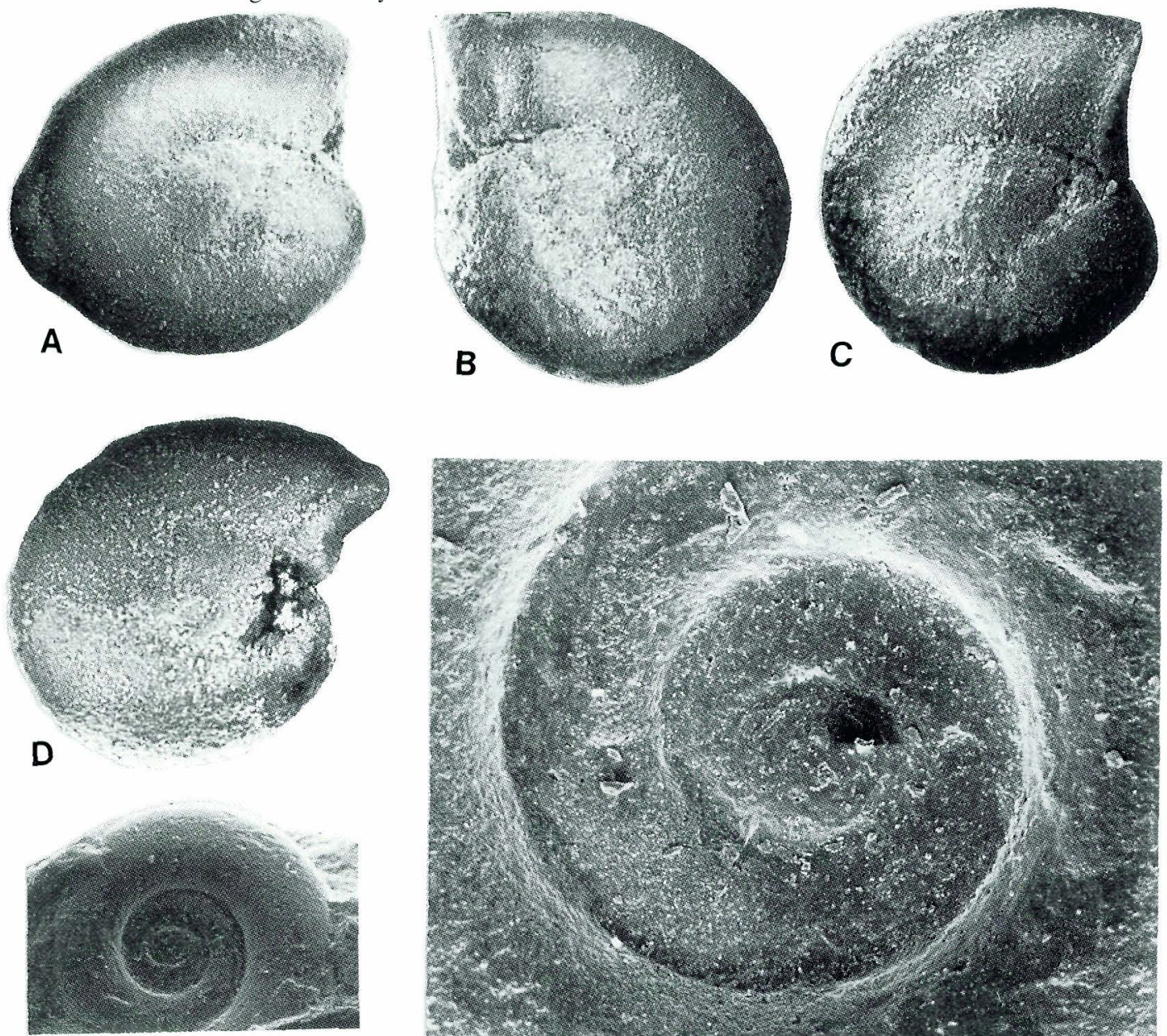

$\mathbf{E}$

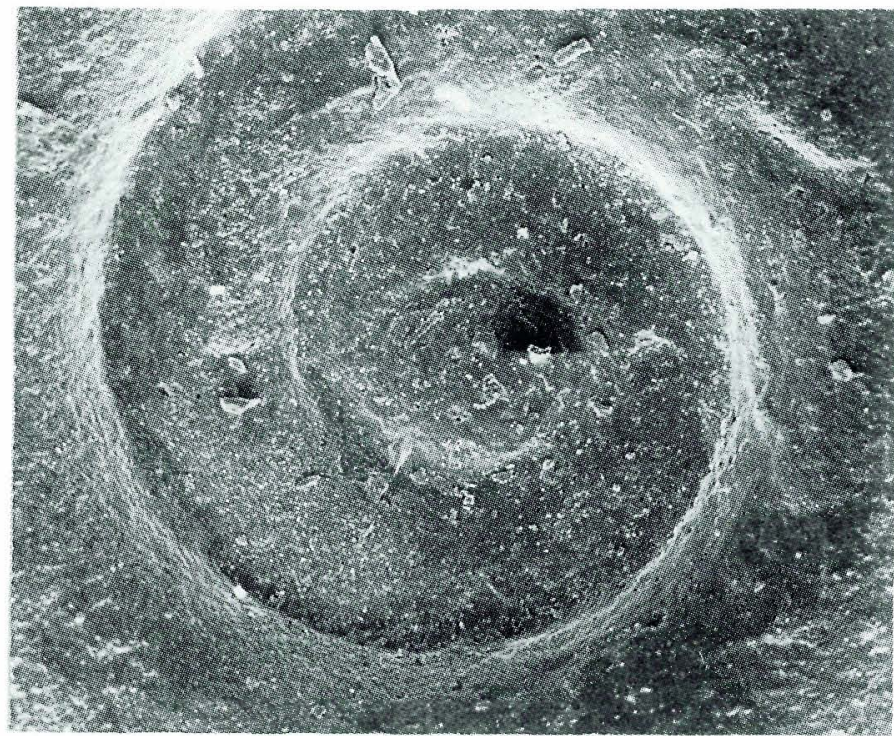

$\mathbf{F}$

Text-fig. 5: A-D, ammonitellas of Baculites or Hoploscaphites. E, F, early growth stages of Saghalinites, from the top Maastrichtian hardground at Stevns Klint. A-D, $\times 40 ; \mathrm{E} \times 12 ; \mathrm{F} \times 50$. A is MGUH 20221, B is MGUH 20222, C is MGUH 20223, D is MGUH 20224, E is MGUH 20225, and $\mathrm{F}$ is MGUH 20226.

wall is the preferential site of silicification and in more advanced stages the fill and the surrounding limestone is also silicified. At several localities along the cliff early diagenetic thrusting of the hardground has taken place (Fig. 4, Surlyk, 1969). This is interpreted as being due to a diagenetically caused volume increase and expansion analogous to the thrusts and folds described by Shinn (1969) from hardgrounds in the Persian Gulf.

The hardground itself contains a diverse fauna comprising among others originally aragonite shelled gastropods and bivalves. Tests of the lower Danian echinoid Brissopneustes danicus are commonly found in the burrow fill.
The erosion surface of the basal Danian hardground formed the foundation for the upbuilding of the very impressive lower Danian bryozoan bioherms.

The Danian bioherms show the same type of asymmetry as those in the top Maastrichtian, but they are large, contain more flint arranged in thick, often continuous, layers and have a much higher grain/matrix ratio. The dominant grains are stems of delicate bryozoans, but whole and fragmented echinoid skeletons are also conspicuous constituents. The biohermal sequence reaches thicknesses of about $20 \mathrm{~m}$ at the southern end of the cliff decreasing to $8-10 \mathrm{~m}$ to the north. This thickness trend together with the overlapping na- 

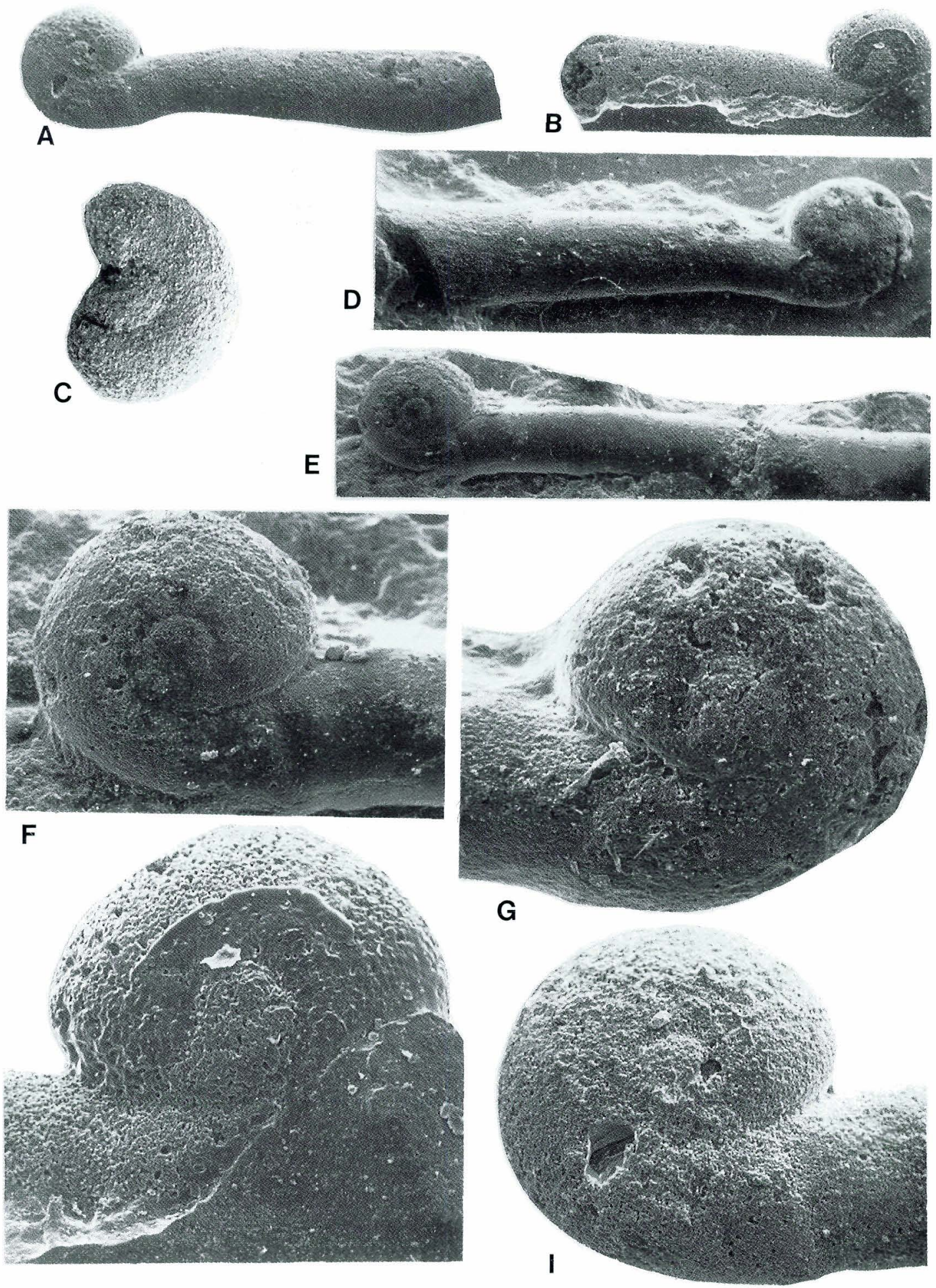

Text-fig. 6. A, B, D-I, early developmental stages of Baculites vertebralis. C, Ammonitella of Baculites or Scaphites, from the top Maastrichtian hardground at Stevns Klint. A, B, D, E, $\times 25 ; \mathrm{C} \times 40 ; \mathrm{F}-\mathrm{I} \times 70$. A is MGUH 20227, B is MGUH 20228, C is MGUH 20229. D is MGUH 20230, E is MGUH 20231, F is MGUH 20232, G is MGUH 20233, H is MGUH 20234, and I is MGUH 20235. 
ture of the bioherms (the northern bioherms overgrow their southern neighbours) suggest a considerable northwards younging of the whole Danian sequence. The bioherms were probably formed by upcurrent growth of bryozoan mounds as described for contemporaneous mounds in eastern Jylland by Thomsen (1976).

Some southern flanks of bioherms are encased by thin hardgrounds which may reach from the summit of the bioherm and right down to the basin between two bioherms. In this way a flank hardground can come into direct contact with the ubiquitous basal Danian hardground which comprises both the Cerithium limestone and the top of the Maastrichtian bioherms. Care in collection of fossils and samples is essential in such cases to avoid mixed faunas (of three different ages).

Apart from hardgrounds the flanks are characterized by abundant evidence of mass-flows such as slurry and debris flows. Thin beds composed solely of skeletal debris without the usual coccolithic matrix may suggest periods of current winnowing. (Surlyk, 1979b, pp. 165-170).

The base of the Danian Fish Clay has been proposed by Surlyk (1984) as defining the upper boundary of the Maastrichtian, with Stevens Klint as reference locality, or Nye Kløv as an alternative if the Stevns section can be demonstrated to contain a hiatus. The Fish Clay contains a marked Iridium anomaly (Alvarez et al., 1980; Smit \& Ten Kate, 1982; Hansen et al. 1988). The International Commission on Stratigraphy has now voted in favour of drawing the Maastrichtian/Palaeogene boundary at the base of the marked Iridium spike at El Kef (Tunisia). If this corresponds to the spike in the Fish Clay, then the boundary actually lies just above the base of this unit (Hansen et al. 1986; Hansen et al. 1988). The biostratigraphic definition of the boundary, based on dinoflagellates lies above the Iridium spike (Hansen et al. 1986). Furthermore, there is evidence for the appearance of Iridium in the White Chalk below the Fish Clay (Hansen et al. 1987) and for diachroneity of microfossil extinctions at this level (Hansen 1990). The completeness or otherwise of the Stevns section is reviewed by Hansen (1979; see also Birkelund \& Håkansson, 1982), who has demonstrated the presence, in expanded successions (such as those at Kjølby Gård, Nye Kløv, and Eerslev, of a dinoflagellate zone of Chriopteridium inornatum
- Palynodinum grallator that may be up to 5 metres thick; this is absent at Stevns (Birkelund \& Håkansson, 1982, fig. 3) and would appear to indicate a minor hiatus.

The ammonites from the Maastrichtian chalks incorporated in the hardground below the intraDanian erosion surface (Text-figure 4) occur as internal and external moulds, with voids representing the position of the original aragonitic shell (Pl. 13, figs. 2, 10, 11). This shows that the aragonite survived within the Maastrichtian chalk into Danian time. Adult and juvenile Hoploscaphites constrictus (Pl. 17, figs. 5-9, 11-23) and Baculites vertebralis (Pl. 13, figs. 1-11) are frequent. Much rarer are specimens, either juvenile or lacking body chamber and thus incomplete, of Hypophylloceras velledaeforme, Saghalinites n.sp., Anapachydiscus aff. fresvillensis (Pl. 4, fig. 3), Diplomoceras cf. cylindraceum and Phylloptychoceras sp. (PI. 3, fig. 2).

Also present in large numbers are ammonitellas - the earliest developmental stages of ammonites - extending only as far as the nepionic constriction (Text-figure 5A-D;6C), as well as minute specimens of Baculites with part of the straight shaft as well as the initial coil (Text-figure $6 \mathrm{~A}, \mathrm{~B}, \mathrm{D}-1)$. Some of the ammonitellas also belong to Baculites, others, probably, to Hoploscaphites.

At neither Kjølby Gård nor Stevns Klint can ammonites be shown to extend, unequivocally, to the top of the Maastrichtian. In the section at Kjølby Gård, they occur in the highest recognised dinoflagellate zone, only $20 \mathrm{~cm}$ below Danian sediments, in what seems to be a continuous succession free of any obvious break in sedimentation (Birkelund \& Håkansson, 1982, p. 376). At Stevns Klint there is probably a break at the boundary, to judge from the dinoflagellate evidence.

It must be stressed that the last ammonites show no indications of dwarfing or stunting, as Wiedmann (1969) initially believed to be the case with the late Maastrichtian fauna of Zumaya (Spain). What is remarkable at Stevns Klint is the abundance of ammonitellas. These are unknown in the underlying White Chalk, and it may be that their abundance in the top Maastrichtian hardground at Stevns records a real biological event. It can be argued, however, that their apparent absence in the White Chalk facies merely reflects 
the dissolution of their aragonitic shells after burial and hence the unlikelihood of such tiny composite moulds being detected; and that their recognition also reflects the minute attention which the hardground faunas have received. Many ammonitellas were in fact found during the meticulous search for minute, originally aragonitic bivalves at this level (Heinberg, 1976, 1979a, b, 1980), which are equally unknown from the White Chalk below.

In summary, the Danish evidence shows ammonites extending to within $20 \mathrm{~cm}$ of the base of the Danian in the apparently continuously deposited sequence at Kjølby Gård, with Hoploscaphites and Baculites. At Stevns Klint, there may be a hiatus at the boundary, and the more diverse assemblage recorded here may reflect the more extensive sampling. Similarly, absence of ammonites in the highest $20 \mathrm{~cm}$ at Kjølby Gård may reflect mere collection failure. The most conservative view is that 7 ammonite taxa were undoubtedly present a few tens of thousands, to a few hundreds of thousand years before the beginning of Danian time. These taxa may have extended to the boundary, or they may not. The taxonomic composition of the assemblage is of some interest, in that all of the Orders of Cretaceous ammonites are represented:

Phylloceratina (Hypophylloceras): Lower Triassic to Upper Maastrichtian.

Lytoceratina (Anapachydiscus): Sinemurian to Upper Maastrichtian.

Ammonitina (Anapachydiscus): Sinemurian to Upper Maastrichtian.

Ancyloceratina (Diplomoceras, Baculites, Phylloptychoceras, Scaphites): Tithonian to Upper Maastrichtian.

\section{Ammonites in the Danian}

Specimens of both Hoploscaphites constrictus and Baculites vertebralis have been collected from the lower part of the Danian limestones at Stevns Klint. The complexities at this locality are such that some specimens in old collections may have been collected from the hardground that caps the Maastrichtian on the topographic highs separating troughs containing Fish Clay (Text-figure 4) and are in situ Maastrichtian fossils. But there are also recently collected specimens that are undoubtedly from the Danian. Some are clearly reworked internal moulds, but some fragments of Baculites are well-preserved. Their sedimentary infilling was checked for nannofossils by Dr. E. Thomsen (Aarhus). It proved to be Maastrichtian chalk, indicating these specimens to be derived. They are also lightly phosphatized $(H . J$. Hansen, personal communication).

There is no evidence for indigenous Danian ammonites in the Danish sequence.

\section{Conventions}

The following abbreviations are used to indicate the sources of specimens cited in the text:

GBA: Geologische Bundesanstalt, Vienna.

MGUH: Geological Museum, Copenhagen.

EMP: Ecole des Mines, Paris, now in the Université Claude Bernard, Lyon.

BM: Natural History Museum, London.

Dimensions are given in the following sequence: $\mathrm{D}=$ diameter; $\mathrm{Wb}=$ whorl breadth; $\mathrm{Wh}=$ whorl height; $\mathrm{Wb} / \mathrm{Wh}=$ whorl breadth to height ratio; $\mathrm{U}=$ umbilical diameter. Figures in parentheses are dimensions as a percentage of the diameter.

Systematic Descriptions.

Order Ammonoidea Zittel, 1884.

Suborder Phylloceratina Arkell, 1950.

Superfamily Phyllocerataceae Zittel, 1884.

Family Phylloceratidae Zittel, 1884.

Subfamily Phylloceratinae Zittel, 1884.

Genus Hypophylloceras Salfeld, 1924.

Type species: Phylloceras onoense Stanton, 1896, p. 74; by monotypy.

\section{Subgenus Neophylloceras Shimizu, 1934}

Type species: Ammonites (Scaphites?) ramosus Meek, 1857, p. 45.

Discussion of the genus and subgenus: see Birkelund (1965, p. 21-22), Matsumoto \& Morozumi (1980) and Henderson \& McNamara (1985). Following the two first mentioned references, Neophylloceras is considered a subgenus of Hypophylloceras and not of Phylloceras as by Henderson \& McNamara because of the considerable difference in sutural complexity between Jurassic and Cretaceous forms. 


\section{Hypophylloceras (Neophylloceras) surya}

(Forbes, 1846)

\section{Pl. 2, fig. 2.}

1846 Ammonites surya Forbes, p. 106, pl. 7, fig. 10.

1907 ?Phylloceras sp. Wisniowski, p. 200, pl. 17, fig. 3.

1956 Epiphylloceras mikobokense Collignon, $\mathrm{p}$. 24 , pl. 2, fig. 3; pl. 4, fig. 5.

1971 Epiphylloceras geczyi Collignon, p. 1, pl. 640, fig. 2360.

1977a Phylloceras (Hypophylloceras) mikobokense (Collignon): Kennedy \& Klinger, p. 368 , pl. 12 , fig. 1 (with synonymy).

1985 Phylloceras (Neophylloceras) surya (Forbes, 1846): Henderson \& McNamara, p. 42 , pl. 1, figs. $7,8,11,12$; pl. 2 , figs. $1-2$; text-fig. $2 \mathrm{~g}$ (with full synonymy).

Types: The original of Forbes (1846, pl. 7, figs. $10 \mathrm{a}-\mathrm{b}$ ) is in the Natural History Museum, London, no. C. 51075). Unfigured syntypes are C. 51076-9.

Locus typicus: Pondicherry, southern India.

Stratum typicum: The Maastrichtian Valudayur beds.

Material: One fragrnent from the Dania Quarry.

Description: The only specimen is a composite external mould of a fragment showing a narrow umbilicus and a finely ribbed surface. The ribbing is almost rectiradiate. Costae are developed on the inner part of the flanks; they are sharpest close to the umbilicus and fade out on the outer part of the flanks.

Discussion: The fragment is closely similar to Hypophylloceras (Neophylloceras) surya in sculpture. According to Henderson \& McNamara (1985) the ornament of that species is quite variable. The present specimen is especially close to the specimen figured by Henderson \& McNamara (1985) as their pl. 1, fig. 11, both in size and sculpture.

Stratigraphy: The specimen is from a loose piece of chalk collected by Professor E. Voigt of Hamburg. Although not found in situ, the speci- men can be firmly referred to the upper Upper Maastrichtian stevensis - chitoniformis brachiopod zone, that being the only part of the Maastrichtian exposed in the Dania quarry. All other occurrences of this species can only be referred to the Maastrichtian in a broad sense. Thus, this is the only specimen which can be firmly dated to the upper Upper Maastrichtian.

Distribution: South India, Madagascar, western Australia, Zululand (South Africa), Denmark.

\section{Hypophylloceras (Neophylloceras) velledaeforme (Schlüter, 1872)}

Pl. 1, figs. 1-2.

1872 Ammonites velledaeformis Schlüter, $\mathrm{p}$. 60 , pl. 18, figs. 4-7.

1902 Phylloceras velledaeforme Schlüter: Ravn, p. 248, pl. 3, fig. 12.

1902 Schlüteria velledaeformis Schlüter: Wollemann, p. 106.

1964 Phylloceras velledaeformis (Schlüter): Giers, p. 255.

1979 Neophylloceras velledaeforme (Schlüter, 1876): Birkelund, p. 53.

non 1982 Phylloceras (Hypophylloceras) velledaeforme (Schlüter): Immel, Klinger \& Wiedmann, p. 8, pl. 1, figs. 3-4.

Lectotype: The original of Schlüter, 1872 (pl. 18, fig. 7), herein designated. Kept in the Museum of Göttingen University, no. 65-3.

Locus typicus: Lüneberg, German Federal Republic.

Stratum typicum: The so-called MucronatenSchichten of Schlüter. This ranges from the Upper Campanian to the lower part of the Lower Maastrichtian at Lüneberg according to Schmid (1962). The Zeltberg profile of Lüneberg has been referred to the Lower Maastrichtian obtusa belemnite zone by Schulz (1979).

Material: 5 specimens, 2 from Ålborg, 1 from Fjerritslev, 1 from the Dania Quarry, and 1 from the hardground at the Maastrichtian-Danian boundary at Stevns Klint. 
Dimensions:

$\begin{array}{lcc} & \mathrm{D} & \mathrm{Wb} \\ \text { PI. 1, fig. } 1 & 54.5(100) & 19.7(36.1)\end{array}$

Description: All specimens are nuclei and badly deformed except for the largest specimen - a silicified one - the dimensions of which are given above.

The specimens show a very narrow umbilicus. At a diameter of $35 \mathrm{~mm}$ the whorl breadth to height ratio is 0.67 and the section is oval with the maximum whorl width at the middle of the flanks.

The surface is covered by extremely fine ribs. They are nearly straight on the early whorls and show a very slight sigmoidal curve on later whorls, bending slightly backwards on the sides and forwards on the venter. In one specimen from the top Maastrichtian ribs coalesce at small intervals close to the umbilicus at a shell diameter of $25 \mathrm{~mm}$.

Sutures can be discerned in the specimen figured by Ravn (1902, pl. 3, fig. 12), and show the great complexity characteristic of the subgenus.

Discussion: The undeformed specimen, figured as Pl. 1 , figs. $1 \mathrm{a}-\mathrm{b}$ is close to $H$. (N.) velledaeforme from Lüneberg as figured by Schlüter (1872, pl. 18, figs. 4-5). It differs from that specimen only in its less depressed cross section, a difference which may very well be due to post mortem deformation of Schlüter's specimen.

The species is extremely rare and the range of variation is unknown. It is therefore also uncertain whether the small nuclei found at the highest stratigraphical level, in "Dania" and at Stevns Klint, should be referred to this species, as they show coalescing ribs at the umbilicus (Pl. 1, fig. 2), a character not seen in later growth stages of $H$. (N.) velledaeforme from lower stratigraphical levels. Similar coalescing ribs are known from other Maastrichtian forms, e.g. $H$. (N.) greenlandicum Birkelund, 1965, from West Greenland.

Stratigraphy: The only well-preserved specimen is from the Ålborg area (precise locality unknown) and comes probably from one of two brachiopod zones: the tenuicostata - semiglobularis zone of the uppermost Lower Maastrichtian or the semiglobularis - humboldti zone of the

$\begin{array}{ccc}\text { Wh } & \text { Wb:Wh } & \mathrm{U} \\ 32.9(60.4) & 0.60 & 6.3(5.5)\end{array}$

lowermost Upper Maastrichtian. Other small nuclei, referred to this species with some doubt, are from the stevensis - chitoniformis brachiopod Zone of the upper Upper Maastrichtian.

All these occurrences are later than that at Lüneberg, where all $25 \mathrm{~m}$ of the classical Zeltberg profile belongs to the upper part of the lower Lower Maastrichtian, the obtusa belemnite zone of Schulz (1979).

Distribution: The species is known only from Lüneberg and Denmark. Specimens described by Wisniowski (1907, p. 200, pl. 1, fig. 8) from the Carpathians and referred to this species by Diener (1925) do not belong here, and Steinmann's (1895) indication of the species from South America (Quiriqina Island, Chile) has not been verified (Stinnisbeck, 1987). Santonian records (Immel et al., 1982) refer to another species, of the group of $H$. woodsi Van Hoepen, 1921.

Genus Anagaudryceras Shimizu, 1934.

Type species: Ammonites sacya Forbes, 1846, p. 113, pl. 14, fig. 9; by original designation.

Discussion of the genus: see Kennedy \& Klinger (1979) and Wright \& Kennedy (1984).

Anagaudryceras lueneburgense (Schlüter, 1872)

Pl. 1, figs. 3-5.

1872 Ammonites lueneburgensis Schlüter, p. 62, pl. 18, figs. 8-9.

1902 Desmoceras lüneburgense Schlüter: Ravn, p. 252.

1979 Gaudryceras lueneburgense (Schlüter): Birkelund, p. 53.

1979 Anagaudryceras lueneburgense (Schlüter): Kennedy \& Klinger, p. 146.

1982 Anagaudryceras lueneburgense (Schlüter): Birkelund, p. 14, pl. 1, fig. 1.

1986 Anagaudryceras lueneburgense (Schlüter, 1872): Kennedy \& Summesberger, p. 185, pl. 3, fig. 6; pl. 15, fig. 4 (with additional synonymy).

Lectotype: The original of Schlüter (1872, pl. 18, figs. 8-9), designated by Birkelund (1982). Kept 
in the museum of Göttingen University, no. $65-4$, where the paralectotype and only other specimen belonging to the type series is also kept.

Locus typicus: Lüneburg.

Stratum typicum: As for Hypophylloceras ( $\mathrm{Ne}$ ophylloceras) velledaeforme (see above).

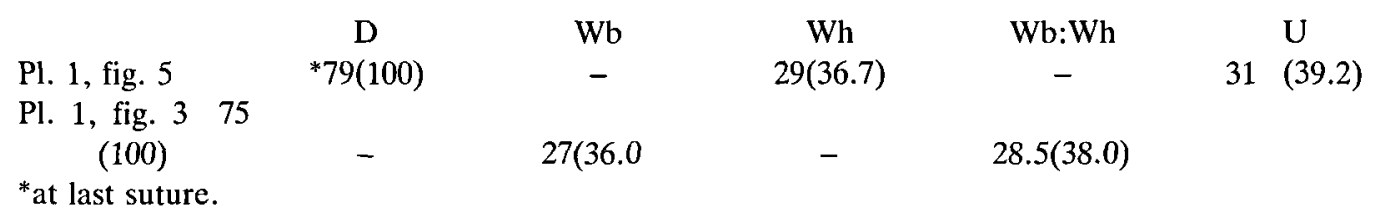

Description: The diameter at the last suture is 79 $\mathrm{mm}$ in the only complete phragmocone. Fragments of body chambers seem to match phragmocones of similar size or slightly larger. Early stages are extremely evolute while later stages become less evolute, the umbilical ratio being about $40 \%$ at the last suture. Only scattered constrictions and flares are visible on the inner whorls. From a diameter of $40-45 \mathrm{~mm}$ to the beginning of the body chamber regular constrictions connected with flares are developed. They are rather weak and only slightly flexuous. The body chamber is characterized by denser and much stronger constrictions and flares, which now become increasingly flexuous, while extremely fine lirae can be distinguished. Very incised suture-lines are preserved in one specimen (Pl. 1, fig. 5), but are too poor for closer description.

Discussion: The large fragment of a body chamber shown in PI. 1 , fig. 4 was referred to Desmoceras lueneburgense by Ravn (1902) and was probably also known to Schlüter (1876, p. 249). This specimen is very close to the lectotype from Lüneburg. The species seem to differ from other Anagaudryceras species by the more distant flares and constrictions on the body chamber. The species was referred to the species group Anagaudryceras buddha by Kennedy \& Klinger (1979, p. 146).

Stratigraphy: The Danish occurrences belong to the tenuicostata - semiglobularis and/or semiglobularis - humboldti brachiopod zones immediately below and above the Lower upper Maastrichtian boundary respectively. These specimens are younger than those from Lüneburg, where
Material: 6 specimens, 2 from Frejlev, 1 from Nørholm 1 from Hillerslev and 2 from Rørdal.

Dimensions: All specimens are slightly crushed. Two fairly complete phragmocones (one with the early part of body chamber preserved) show the main dimensions.

the Zeltberg profile belongs to the obtusa belemnite zone of the upper lower Lower Maastrichtian (Schulz, 1979). At Hemmoor, Northern Germany, one specimen is known from the semiglobularis - humboldti brachiopod zone, in good accord with the Danish occurrences. The material from Neuberg, Steiermark, Austria is dated as upper Lower Maastrichtian sumensis belemnite zone (Kennedy \& Summesberger, 1986).

Distribution: Besides occurrences in Lüneburg, Hemmoor and Denmark the species is recorded from Rügen by Schlüter (1876) and from Tercis, Landes (France) by de Grossouvre (1894, p. 231; Kennedy \& Summesberger, 1986, p. 188) and Neuberg, Steiermark, Austria (Kennedy \& Summesberger 1986). Other very doubtful occurrences are in Scania (Moberg 1885, p. 24) and the Carpathians (Wisniowski 1907).

Genus Saghalinites Wright \& Matsumoto, 1954.

Type species: Ammonites cala Forbes, 1846, p. 104, pl. 8, fig. 4; by original designation.

Discussion of the genus: see Birkelund (1965), Kennedy \& Klinger (1977b) and Kennedy \& Summesberger (1986).

\section{Saghalinites wrighti Birkelund, 1965}

Pl. 1, figs. 6-7; pl. 2, figs. 1, 3, 4, 6 .

1876 Ammonites sp. n. Schlüter, p. 161, pl. 42 , figs. 6-7.

1902 Ammonites n. sp? Schlüter: Ravn, p. 257, pl. 3, fig. 11 .

1965 Saghalinites wrighti Birkelund, p. 30, pl. 1, fig. 5; pl. 2, figs. $1-5$; pl. 3 , fig. 1 ; text-figs. 14-25. 
1979 Saghalinites n. sp. aff. wrighti Birkelund, p. 53.

non 1982 Saghalinites aff. wrighti Birkelund; Immel, Klinger \& Wiedmann, p. 10, pl. 2 , figs. $1,2$.

1982 Saghalinites wrighti Birkelund: Birkelund, p. 15 , pl. 1 , figs. 2,3 .

non 1984 Saghalinites wrighti Birkelund: Haczewski \& Szymakowska, p. 651, pl. 1, fig. 2.

1986 Saghalinites wrighti Birkelund: Kennedy \& Summesberger, p. 186, pl. 1, figs. $4,5,7 ;$ pl. 3 , fig. 4 ; text-fig. 3 .

\begin{tabular}{ll} 
& \multicolumn{1}{c}{$\mathrm{D}$} \\
Pl. 1, fig. 6 & $38.9(100)$ \\
Pl. 1, fig. 7 & $45(100)$ \\
Pl. 1, fig. 3 & $65(100)$ \\
Pl. 2, fig. 4 & $67(100)$ \\
PI. 2, fig. 1 & $75.5(100)$
\end{tabular}

$\mathrm{Wb}$

$15.0(38.6)$

$-(-)$

$-(-)$

$-(-)$

$-(-)$

Description: The only specimen with the final peristome preserved is $71 \mathrm{~mm}$ in diameter (Pl. 2, fig. 3), but fragmentary specimens are slightly larger. The umbilical ratio is $41-45 \%$. The whorl section is evenly rounded and slightly depressed on the inner whorls as seen in Pl. 1, fig. 6 , while the youngest 1-2 whorls, although crushed, may show the characteristic octagonal cross-section of the genus with flattened venter, flattened ventrolateral shoulders and flanks, and a well-defined umbilical slope forming an obtuse angle with the flanks.

Constrictions are not visible in most of the specimens. This may partly be due to the presence of a calcitic replacement of the shell wall in some. Only in one, from Nørre Uttrup (figured by Ravn 1902, pl. 3, fig. 11), can a few constrictions be seen on the inner whorls. A strong constriction is developed close to the final peristome in the mature specimen (Pl. 2, fig. 3).

One specimen (Pl. 2, fig. 4) shows fairly wellpreserved suture lines very similar to a suture of $S$. wrighti at a similar whorl height figured by Birkelund (1965, fig. 21).

Discussion: These specimens are referred to Saghalinites wrighti with some hesitation because of the poor preservation. However, the close sim-
Holotype: The original of Birkelund, 1965, (pl. 2, figs. 5a-c, text-fig. 19) by original designation. Kept in the Geological Museum, Copenhagen (MGUH 9747).

Locus typicus: Nûgssuaq, West Greenland.

Stratum typicum: Oyster-ammonite conglomerate, locality III, Maastrichtian.

Material: 11 specimens, 1 from Rørdal, 1 from "Danmark", 1 from Nørre Uttrup, 5 from Hillerslev and 3 from Frejlev.

Dimensions: All the specimens are crushed except for two silicified specimens from Frejlev, shown in Pl. 1, figs. 6-7.

$\begin{array}{ccc}\text { Wh } & \mathrm{Wb} / \mathrm{Wh} & \mathrm{U} \\ 13.2(33.9) & 1.1 & 15.8(41) \\ -(-) & - & 20.0(44) \\ -(-) & - & 30.5(45) \\ -(-) & - & 30(45) \\ -(-) & - & 33.5(44)\end{array}$

ilarity in size, umbilical ratio, expansion rate and peristome support this determination. The rare occurrence of constrictions on the inner whorls in comparison with the type material of $S$, wrighti is ascribed to differences in preservation. A few constrictions can be discerned in a specimen from Hemmoor (Birkelund 1982, pl. 1, figs. 2-3) and also in poorly preserved specimens from Neuberg (Steiermark, Austria) (Kennedy \& Summesberger, 1986, p. 186, pl. 1, figs. 4, 5, 7; pl. 3, fig. 4).

Stratigraphy: All the material from Denmark belongs to the tenuicostata - semiglobularis and/or semiglobularis - humboldti brachiopod zones immediately below and above the Lower/ Upper Maastrichtian boundary respectively. The exact level of the specimen described by Birkelund (1982) from Hemmoor is unknown. The age of poorly preserved specimens from Neuberg (Austria), referred to this species by Kennedy \& Summesberger (1986) are middle to upper sumensis zone on the basis of associated nannofossils, that is to say upper Lower Maastrichtian. The type series of $S$. wrighti is from the Maastrichtian of West Greenland, where its occurrence together with Discoscaphites related to $D$. nebrascensis (Owen, 1852) from the Fox Hills 
Sandstone of the Western Interior of United States suggest upper Lower Maastrichtian or lower Upper Maastrichtian (see Obradovich \& Cobban, 1975) and dinoflagellate cysts from these deposits seem to indicate a similar level (J.

M. Hansen, pers. comm., 1985).

Distribution: The species is known from Northern Germany, Austria, Denmark and West Greenland. A specimen found in the Cretaceous flysch of southern Poland by Haczewski \& Szyrnakowska (1985) is of much larger size than any $S$. wrighti known up to now and probably belongs to a different species.

\section{Saghalinites n. sp.}

Pl. 2, figs 5, 7; pl. 3, fig. 1.

? 1908 Gaudryceras cf. kayei Forbes: de Grossouvre, p. 34 , pl. 10, fig. 5.

1925 Gaudryceras cf. kayei (Forbes) de Grossouvre: Diener, p. 48.

1979 ?Vertebrites kayei sensu de Grossouvre: Kennedy \& Klinger, p. 160.

1979 Saghalinites n. sp. Birkelund, p. 53.

1982 Saghalinites sp. Birkelund, p. 15.

1987 Saghalinites sp. Kennedy, p. 160, pl. 21, figs. 1,4 ; text-fig. 7D.

Material: 4 specimens, 2 from Hov, 1 from Bjerre and 1 from the Dania Quarry. One barely determinable specimen from Flødal, referred to as Ammonites n.sp? by Ravn (1902) may belong here, as also may juvenile specimens from Stevns Klint.

\section{Dimensions:}

\begin{tabular}{|c|c|c|}
\hline \multirow{3}{*}{ Pl. 3, fig. 1} & D & $\mathbf{U}$ \\
\hline & $82.0(100)$ & $38.4(47)$ \\
\hline & $77.6(100)$ & $37.0(48)$ \\
\hline Pl. 2, fig. 7 & $26.4(100)$ & $12.5(47)$ \\
\hline \multicolumn{3}{|c|}{$\begin{array}{l}\text { de Grossouvre, } 1908, \\
\text { pl. } 10 \text {, fig. } 5 \text { (here }\end{array}$} \\
\hline$(2$, fig. 6$)$ & $31.6(100)$ & $14.2(44$. \\
\hline
\end{tabular}

Description: All the specimens are badly crushed. The biggest one, a mature individual from Hov, is $96 \mathrm{~mm}$ in diameter. It has a wide umbilicus, a few weak constrictions on the inner whorls and a strong constriction $2 \mathrm{~cm}$ from the final peristome. The body chamber extends to nearly $270^{\circ}$ of a whorl. Two small nuclei show a similar wide umbilicus and weak constrictions, but no constrictions are seen on the very earliest whorls of a juvenile specimen, which may belong here.

Sutures are similar to those of Saghalinites wrighti.

Discussion: The specimens differ from Saghalinites wrighti by their wider umbilicus and lower expansion rate, and by showing no sign of an octagonal cross-section on the younger whorls, which may be due to crushing. The suture line seems to support assignment to the genus Saghalinites in spite of the lack of an octagonal whorl section, one of the most important diagnostic characters of the genus.

A specimen referred to Gaudryceras cf. kayei Forbes by de Grossouvre (= ?Vertebrites kayei according to Kennedy \& Klinger, 1979 and = Saghalinites sp. according to Kennedy (1987)) may also belong to this species although the umbilicus is slightly narrower (see Pl. 2, fig. 5).

Stratigraphy: The Danish specimens occur in the Upper Maastrichtian ?humboldti - stevensis and stevensis - chitoniformis brachiopod zones.

Distribution: The only other, doubtful occurrence of this species outside Denmark is in The Netherlands (Kunraede Limestone), dated as lower Upper Maastrichtian, junior zone.

Suborder Ammonitina Hyatt, 1889.

Superfamily Desmocerataceae Zittel, 1895.

Family Pachydiscidae Spath, 1922.

Genus and Subgenus Pachydiscus Zittel, 1884.

Type species: Ammonites neubergicus Hauer, 1858 , p. 12 , pl. 2 , figs. $1-3$; pl. 3 , figs. 1,2 ; by subsequent designation by de Grossouvre, 1894, p. 177.

Discussion of the genus and subgenera: see Kennedy \& Summesberger (1986) and Kennedy (1986b).

Pachydiscus (Pachydiscus) neubergicus (von Hauer, 1858)

Pl. 4, figs. 1-2; Pl. 8, fig. 1; Pl. 10, fig. 1.

1858 Ammonites neubergicus v. Hauer, p. 12 (pars), pl. 2, figs. 1-3, non pl. 3, figs. 1-2.

1869 Ammonites neubergicus v. Hauer: Favre, p. 14 , pl. 4, figs. 2-3.

1872 Ammonites neubergicus v. Hauer: Schlüter, p. 59, pl. 18, figs. 1-3. 
1873 Ammonites neubergicus v. Hauer: Redtenbacher, p. 120, pl. 27, fig. 5.

1894 Pachydiscus neubergicus v. Hauer: de Grossouvre, p. 207 (pars), pl. 30, fig. 4 (non pl. 26, fig. 3; pl. 38, fig. 3, text-fig. 80 $=$ Pachydiscus jacquoti Seunes, 1890).

1979 Pachydiscus neubergicus (v. Hauer): Birkelund, p. 56.

1980 Pachydiscus neubergicus raricostatus Blaszkiewicz, p. 43 (pars), pl. 36, figs. 1-4, 7-10; ? non pl. 35, figs. 6-8.

1980 Pachydiscus neubergicus neubergicus (v. Hauer): Blaszkiewicz, p. 44, pl. 35, figs. 4-5; pl. 36, figs. 5-6.

1986 Pachydiscus (Pachydiscus) neubergicus (von Hauer, 1858); Kennedy \& Summesberger, p. 189, pl. 2, figs. 1, 2; pl. 3, figs. 1-3; pl. 4, figs. 1-5; pl. 5, figs. 1, 4, 5; pl. 6 , figs. 1,2 ; pl. 15 , figs. 7,8 ; text-fig. 5A, B (with full synonymy).

?1988 Pachydiscus (Pachydiscus) cf. neubergicus (Hauer, 1858); Vašiček, p. 76, pl. 1, fig. 3.

Lectotype: GBA 1858.01.6 the original of Hauer 1858 p. 12 , pl. 2, figs. 1-2. Designated by de Grossouvre 1894, p. 209 (see Kennedy \& Summesberger 1986, pl. 3, figs. 1-3).

Locus typicus: Neuberg, Steiermark, Austria.

Stratum typicum: Upper Lower Maastrichtian, middle to possibly upper part of sumensis zone (see Kennedy \& Summesberger 1986, p. 200).

Material: 4 specimens, 1 from Rørdal, 1 from Hillerslev, 1 from Lindholm and 1 from drift in Lynge gravel pit.

Description: All 4 specimens are flattened nuclei. The best preserved specimen, found loose in Lynge gravel pit (Pl. 10, fig. 1), has an umbilical ratio of $28 \%$ at a diameter of $95 \mathrm{~mm}$, and the specimen from Rørdal (figured in Pl. 4, fig. 1) has an umbilical ratio of c. $30 \%$ at a diameter of 75 $\mathrm{mm}$. The early part of the shell is slightly more involute (e.g. the Lindholm specimen; Pl. 8, fig. 1). Primary ribs arise close to the umbilical seam and are straight up to a diameter of $65 \mathrm{~mm}$, then curve backwards at the umbilicus and become prorsiradiate on the outer parts of the flanks. They are strengthened on the inner third of the flanks, giving rise to umbilical bullae. Intercalated or bifurcating secondaries appear on the middle part of the flanks. The specimen from Lynge gravel pit (PI. 10, fig. 1) shows 15 primar- ies and about 44 ventral ribs at a diameter of 95 $\mathrm{mm}$, while the other three specimens have a slightly lower proportion of ventral ribs in relation to primaries. The younger parts of the shell are not preserved in the present material.

Complex suture lines are visible, but poorly preserved.

Discussion: The Danish specimens are close to material from the type locality of the species recently redescribed by Kennedy \& Summesberger (1986). Both lectotype and topotypes seem to differ only in having slightly finer ribbing and generally a slightly higher proportion of ventral ribs in relation to primaries.

In ribbing pattern the Danish material, especially the specimen shown in Pl. 10 , fig. 1 , is extremely close to the specimen from Lüneberg figured by Schlüter (1872, pl. 18, figs. 1-3), and also to material figured by Blaszkiewicz (1980) as Pachydiscus neubergicus raricostatus Blaszkiewicz 1980 (p. 43, pl. 36, figs. 1-4 7-10; ? pl. 35, figs. 6-8); it should be mentioned that Blaszkiewicz also refers Schlüter's specimen from Lüneberg to the subspecies raricostatus. However, the holotype of $P$. neubergicus raricostatus is so close to topotypes of $P$. neubergicus sensu stricto that Kennedy \& Summesberger (1986) did not separate the subspecies. Thus, according to the photographs the holotype of $P$. neubergicus raricostatus (Blaszkiewicz, 1980, pl. 36, figs. 3, 4, 8) has 14 umbilical bullae and more than 40 ventral ribs, with the rib bifurcations no more pronounced than is occasionaliy to be seen in topotypes of $P$. neubergicus. Three of Blaszkiewicz's figured specimens (pl. 36, figs. 1-2; the holotype, pl. 36, figs. 3, 4, 8; and pl. 36, figs. 7, 9, 10) are therefore referred to $P$. neubergicus sensu stricto by Kennedy \& Summesberger (1986). Only the one specimen figured by Blaszkiewicz in pl. 35, figs. $6-7$, is considered so sparcicostate that it may be regarded as another form.

Differences between $P$. neubergicus from Europe and subspecies dissitus Henderson \& McNamara, 1985 (p. 72, pl. 7, fig. 7; pl. 9, figs. $3-6$; text-figs. 11, 12c, 13c) from western Australia are outlined by those authors and by Kennedy \& Summesberger (1986, p. 191).

Stratigraphy: The best preserved specimen from Denmark (Pl. 10, fig. 1) is unfortunately from drift, but the three other specimens are stratigraphically fairly well located. The speci- 
men from Lindholm is from the lower Upper Maastrichtian semiglobularis - humboldtii brachiopod zone (lower part of the junior belemnite zone), while the quarries from which the other two specimens " come from (Hillerslev, . Rørdal) expose this zone and the upper Lower Maastrichtian tenuicostata - semiglobularis brachiopod zone (in Rørdal covering the cimbrica and fastigata belemnite zones).

The age of the type material of Pachydiscus neubergicus from Neuberg has been extensively discussed by Kennedy \& Summesberger (1986). On the basis of new analysis of nannofossils from the type locality they refer the lecto- and topotype material to the lower part of the upper Lower Maastrichtian.

Schulz, Ernst, Ernst \& Schmid (1984) refer $P$. neubergicus from Lüneberg to the upper part of the lower Lower Maastrichtian (obtusa belemnite zone), while Blaszkiewicz (1980)refers Polish material of $P$. neubergicus raricostatus to the lower Lower Maastrichtian lanceolata belemnite zone and $P$. neubergicus neubergicus to the upper Lower Maastrichtian sumensis belemenite zone. Elsewhere, where well localized, $P$. neubergicus is Lower Maastrichtian (Kennedy \& Summesberger, 1986).

Thus, it seems that the three Danish specimens are younger than most other occurrences of $P$. neubergicus in Europe, apart from those in the Vistula Valley, Poland.

Distribution: Denmark, north Germany, Austria, Czechoslovakia(?), USSR, Poland, France, Nigeria, southern India, Zululand (South Africa), western Australia.

Genus Anapachydiscus Yabe \& Shimizu, 1926.

Type species: Pachydiscus fascicostatus Yabe, 1921, p. 57 (5), pl. 8 (1), fig. 5; pl. 9 (2), figs. 2-5; by original designation.

Anapachydiscus aff. fresvillensis (Seunes, 1890)

Pl. 4, figs. 3-6; Pl. 5; Pl. 6, figs. 1-4; Pl. 7. Compare:

1861 Ammonites colligatus Binkhorst, p. 25 (pars), pl. 6, fig. 3a-f(?); pl. 7, fig. 2c; pl. 8 a, figs. 1 and 2 only.

1890 Pachydiscus fresvillensis Seunes, p. 3, pl. 2 (1), fig. 1.

1979 Pachydiscus aff. colligatus (v. Binkhorst); Birkelund, p. 56. 1986a Anapachydiscus fresvillensis (Seunes, 1890): Kennedy, p. 160, fig. 8D-F.

1986b Anapachydiscus fresvillensis (Seunes, 1890a): Kennedy, p. 42, pls. 7,8; pl. 9, figs. 1-3; text-figs. 3M, N, Q, $4 \mathrm{~A}$ (with full synonymy).

1986c Anapachydiscus fresvillensis (Seunes, 1890): Kennedy, p. 1008, pl. 1, figs. 4, 5.

1987 Anapachydiscus fresvillensis (Seunes, 1890): Kennedy, p. 173, pl. 6; pl. 7, figs. 1 , $2 ;$ pl. 8; pl. 9, figs. 1, 2; pl. 10, figs. $1-5 ; \mathrm{pl}$. 11 , figs. 5,6 ; pl. 10 , figs. $1-5$; pl. 11, figs. 5 , 6 ; pl. 12 , figs. $12-14$; pl. 13 , figs. 6,7 ; pl. 14 , figs. $1-3,7,11,12$; pl. 15 , figs. $4-6$, pl. 23 , fig. 5 (with full synonymy).

1987 Anapachydiscus fresvillensis quiriquinae (Steinmann); Stinnisbeck, p. 221, pl. 14, fig. 1 ; pl. 16, fig. 1; text-fig. 28 b.

Material: 34 specimens 21 from "Dania", 3 from Kjølbygaard, 1 from Bjerre, 1 from Eerslev, 1 from south of the Aggersundbro, and 7 from Stevns Klint.

Description: All the specimens are crushed and it is therefore not possible to reconstruct the cross-section. The largest specimen is still septate at a diameter of $250 \mathrm{~mm}$ (Pl. 7) and fragments of body chambers show that the species often reached a very large size. Other specimens (PI. 5) show the last suture at a considerably smaller size and may be juveniles.

The umbilical ratio is $16-20 \%$, but because of crushing difficult to determine exactly. The innermost whorls, up to a diameter of $20 \mathrm{~mm}$, are smooth. Three bullae appear at the umbilical margin and later, ribbing appears. Up to a diameter of $100 \mathrm{~mm}$ weak umbilical bullae are developed at irregular intervals at the umbilical seam, giving rise to paired ribs. Between the bullae both paired and single ribs are developed. When the bullae disappear the point of branching of the ribs tends to move from the umbilical shoulder to the inner flank. The ribs are narrow and prorsiradiate. The rib density shows a wide range of variation, with over 7 ribs per whorl in some big specimens.

From about a diameter of $100 \mathrm{~mm}$ ribbing begins to fade on the flanks, and the inner part of the flanks gradually becomes more or less smooth. In most specimens the ribs show a very regular pattern. Only in one specimen (PI. 7) 
does the ribbing on the venter and shoulders show an irregular alternation between sharp and blunt ribs.

Sutures are very incised, but poorly preserved.

Discussion: Anapachydiscus fresvillensis and Ammonites colligatus von Binkhorst, 1861, have been persistently confused in the literature. Kennedy (1987), on the basis of a very detailed analysis of the type Maastrichtian ammonites, has shown that the two species are well separated and belong to difterent genera, Anapachydiscus and $P$. (Pachydiscus). $P$. (P.) colligatus belongs to a much earlier stratigraphic level - Campanian rather than to the Upper Maastrichtian level of A. fresvillensis (Kennedy, 1986a-c, 1987).

It is difficult to compare the Danish material with the holotype of $A$. fresvillensis and other material from the Calcaire à Baculites of the Cotentin Peninsula in Manche, France, because the Danish specimens are crushed and preserved as composite moulds and not as simple steinkerns. The ribbing pattern of the Danish material shows a wide range of variation, but is in good general agreement with holo- and topotypes of $A$. fresvillensis in having umbilical bullae developed on the early whorls. The fading out of the ribs on the flanks of the later whorls is also in good agreement, and confirm it is an Anapachydiscus. An irregular alternation between ribs of different strength (see $\mathrm{Pl}$. 7) is also seen in A. fresvillensis figured by Binkhorst (1861, pl. 8, figs. .1-2; see Kennedy, 1987, pls. 6, 7). The most marked difference in ribbing pattern is the closer ribbing in Danish specimens, for typical $A$. fresvillensis has only 40 or so ribs per whorl in middle growth. In conclusion, the specimens are regarded as close to $A$. fresvillensis, but may represent a new, late species or subspecies.

Stratigraphy: All the Danish occurrences of this species belong to the upper Upper Maastrichtian stevensis - chitoniformis brachiopod zone. Other records are also from high in the Maastrichtian.

Distribution: Anapachydiscus aff. fresvillensis occurs in Denmark, the Biscay region of France and Spain, and Azerbaijan (Alizade et al., 1988, pl. 27, fig. 6).

Suborder Ancyloceratina Wiedmann, 1966.

Superfamily Turrilitaceae Gill, 1871.

Family Diplomoceratidae Spath, 1926.

Subfamily Diplomoceratinae Spath, 1926.
Genus Glyptoxoceras Spath, 1925.

Type species: Hamites rugatus Forbes, 1846, p. 117 , by original designation.

Glyptoxoceras cf. tenuisulcatum (Forbes, 1846)

P1. 2, fig. 8 .

1846 Hamites tenuisulcatus Forbes, p. 116, pl. 10, fig. 8; pl. 11, figs. 3a-d.

1865 Anisoceras tenuisulcatum Forbes sp.; Stoliczka, p. 177, pl. 85, figs. 14-16.

1895 Hamites (Anisoceras) tenuisulcatus Forbes: Kossmat, p. 147, pl. 19 (5), figs. 5a-b, 6a-b.

1959 ?Diplomoceras tenuisulcatum Matsumoto, p. 168.

1979 Glyptoxoceras cf. indicus (Forbes): Birkelund, p. 55.

Lectotype: The original of Forbes (1846, pl. 10, fig. 8), designated by Matsumoto 1959 , p. 168, kept in the Natural History Museum, London, (BM C. 51104, previously BM 10493).

Locus typicus: Pondicherry, India.

Stratum typicum: The Maastrichtian Valudayur beds.

Material: One specimen from Hillerslev.

Description: The specimen is $45 \mathrm{~mm}$ long, 5 to $9 \mathrm{~mm}$ wide and seems to be evenly rounded in cross section. It shows a Crioceras-like coiling. The surface is covered by extremely fine ribs varying in density from 24 per $\mathrm{cm}$ in the earliest part to 10 per $\mathrm{cm}$ in the latest part of the fragment. No constrictions of any sort are visible.

Discussion: The fragment is referred to Glyptoxoceras tenuisulcatum mainly on the basis of the extremely fine ribbing. Thus, the lectotype shows a similar rib density at comparable diameters. The earlier parts of the shell are not well preserved in the lectotype, but are well known from the figures of Kossmat (1895, pl. 19 (5), figs. 5-6), Forbes (1846, pl. 11, fig. 3a) and other specimens in the Natural History Museum, London, and show a similar fining of the ribbing towards the apex.

The initial part of Glyptoxoceras tenuisulcatum shows a loose, low helical coiling. This is followed by a very long, almost straight part (seen in the lectotype) and finally by a U-shaped part, not preserved in the lectotype.

Stratigraphy: Hillerslev seems to span the $t e$ - 
Tab. 1. Rib index of Diplomoceras cylindraceum. - Danish localities:

\begin{tabular}{lcr}
\hline & $\begin{array}{c}\text { *Whorl height } \\
\text { mm }\end{array}$ & $\begin{array}{c}\text { Number of } \\
\text { ribs }\end{array}$ \\
\hline Møns Klint & 11.5 & 10 \\
"Dania" (Pl. 9, fig. 1) & 17.5 & 9 \\
Nørre Flødal & 18.2 & 11 \\
Erslev & 19.4 & 8 \\
Frejlev & 28.8 & 10 \\
Ålborg (PI. 11, fig. 2) & 45.0 & 13 \\
Ålborg (Pl. 11, fig. 3) & 38.5 & 12 \\
"Dania" & 39.6 & 12 \\
Nøarre Uttrup & 40.1 & 10 \\
Gudumlund (Pl. 11, fig. 5) & 41.5 & 13 \\
Frejlev & 42.9 & 14 \\
Frejlev & 47.4 & 13 \\
Møns Klint & 49.5 & 13 \\
Bjerre (Pl. 11, fig. 1) & 50.8 & 14 \\
Ålborg & 52.5 & 11 \\
& 56.8 & 18 \\
"D. cylindraceum ivovensis" & & \\
Nowak 1913, pl. 41, fig. 10 & & \\
(holotype) & 25.8 & 12 \\
& 31.0 & 15 \\
Michailov 1951, pl. 2, fig. 7 & c. 29 & 17 \\
Michailv 1951, pl. 2, fig. 8 & c. 40 & 21 \\
Blaskiewicz 1980, pl. & & \\
\hline
\end{tabular}

nuicostata - semiglobularis and semiglobularis humboldti brachiopod zones, belonging to the uppermost part of the Lower Maastrichtian and the lowermost part of the Upper Maastrichtian respectively.

Distribution: South India, Denmark.

Genus Diplomoceras Hyatt, 1900.

Type species: Baculites cylindracea Defrance, 1816 , p. 160 , by original designation.

\section{Diplomoceras cylindraceum (Defrance, 1816)}

Pl. 3, figs. 3-4; PI. 9, fig. 1; PI. 11, figs. 1-5; PI. 12.

1816 Baculites cylindracea Defrance, p. 160.

1842 Hamites cylindraceus Defrance: d'Orbigny, p. 551, pl. 136, figs. $1-4$.

1902 Hamites cylindraceus Defrance: Ravn, p. 249.

1979 Diplomoceras cylindraceum (Defrance): Birkelund, p. 55.

1986 Diplomoceras lambi Spath, 1953: Macellari, p. 17, figs. 11.13, 14.1, 15, 16.

1986a Diplomoceras cylindraceum (Defrance): Kennedy, p. 160, fig. 9H.

1986b Diplomoceras cylindraceum (Defrance): Kennedy, p. 51, pl. 4, figs. 1-2; pl. 9, figs. 8-10; pl. 10; text-figs. 31-L, 6, 7G-M.
1986 Diplomoceras cylindraceum (Defrance): Kennedy \& Summesberger, p. 194, pl. 15, figs. $1,2,5$; pl. 16 , figs: 14,15 ; text-fig. 6 .

1987 Diplomoceras cylindraceum (Defrance, 1816); Kennedy, p. 181, pl. 17, fig. 3; pl. 18 , fig. 5 ; pl. 21, figs. $2,3,5,6$; pl. 22, fig. 6 ; pl. 23, figs. 1,2 ; pl. 24 , figs. $1,2,3$; pl. 25 , figs. $1-8$; pl. 26 , fig. 18 ; pl. 33 , fig. 16 ; pl. 36, fig. 6; text-figs. 9, 10 (with full synonymy).

1987 Diplomoceras (Diplomoceras) cf. notabile Whiteaves: Stinnisbeck, p. 200.

Type: Defrance (1816) gave no illustrations of the species but a description, which is considered a perfectly valid diagnosis by Kennedy (1986b, p. 52). The locality was given as Maastricht, but according to Kennedy (1986b, p. 52) Defrance's specimens have not been traced. A neotype from the Maastricht area was designated by Kennedy in his revision of type Maastrichtian ammonites (Kennedy, 1987, p. 183, pl. 24, figs. 1-3).

Material: 30 specimens, 4 from Møns Klint, 3 from Ålborg, 2 from Rørdal, 1 from Nørre Uttrup, 1 from Nørre Sundby, 1 from "Danmark", 1 from Lindholm, 4 from. Frejlev, 2 from Gudumholm, 1 from Nørre Flødal, 2 from Eerslev, 1 from Bjerre, 4 from the Dania Quarry, 1from "Bleghule", 1 from Stevns Klint and one without indication of locality.

Description: All the specimens are badly flattened. Fragments show early and late parts of the straight shafts, and the last U-curve of the shell. The most complete septate specimen, described by Ravn (1902, p. 249), but not figured by him, is shown here in PI. 12. It shows a maximum whorl width of $68 \mathrm{~mm}$ at the last preserved suture and the length of the preserved part of the final shaft is $42 \mathrm{~cm}$. An even larger specimen from Ålborg is a body chamber and consists of two shafts, the larger $40 \mathrm{~cm}$ long, with a maximum preserved whorl height of $90 \mathrm{~mm}$. The ribs are sharp in all specimens and separated by relatively much wider interspaces, especially in late growth stages. They are regularly spaced and slightly prorsiradiate except in U-shaped parts of the shell where they are rectiradiate. Rib index (defined as number of ribs in a distance equal to the whorl height) varies from 10 to 18 at whorl heights from 38 to $57 \mathrm{~mm}$. At smaller whorl heights much denser ribbing is seen in some spec- 
imens but the rib index is generally 8-11 at whorl heights of 11-29 mm. Parts of the complex suture iine can be seen in Pl. 11, fig. 5 .

Discussion: Diplomoceras cylindraceum is here interpreted in the same wide sense as by Kennedy (1986a-b, 1987). As all the Danish material is badly flattened, only the general shape and ribbing pattern can be compared with material of this cosmopolitan heteromorph described from other areas. The Danish material seems to be in good agreement - as far as morphology is preserved - with forms referred to $D$. cylindraceum by Kennedy (1986a-b, 1987). However, it is worth mentioning that the subspecies $D$. cylindraceum ivovense, established by Mikhailov (1951) is generally finer ribbed than Danish material. In Table 1 the rib index of the holotype of D. cylindraceum ivovense, figured in Nowak (1913, pl. 41, fig. 10), and other specimens referred to that subspecies by Mikhailov (1951, pl. 2, figs. 7-8) and Blaszkiewicz (1980, pl. 54, fig. 4 ), is compared with that of Danish material. Kennedy \& Summesberger (1987) stress that the supposedly characteristic whorl section of $D$. cylindraceum Ivovense is due to post-mortem crushing. The slightly finer ribbing is hardly characteristic enough to keep this subspecies separate from D. cylindraceum s.str., which occurs together with it.

Stratigraphy: $D$. cylindraceum is known from the Lower Maastrichtian as well as from the Upper Maastrichtian of Denmark. The earliest occurrence is in the lower Lower Maastrichtian $o b$ tusa belemnite zone (acutirostris - spinosa brachiopod zone) and it has been recorded up to the upper Upper Maastrichtian (stevensis - chitoniformis brachiopod zone). There are no obvious changes from early to late forms of the species. According to Blaszkiewicz (1980) " $D$. cylindraceum ivovense" occurs only in the Upper Maastrichtian, but he indicates that $D$. cylindraceum s.str. is also restricted to that part of the sequence.

Distribution: When interpreted in the same wide sense as by Kennedy $(1986,1987) D$. cylindraceum has a near world-wide distribution with records from Europe and the USSR, southern India(?), Zululand, Madagascar, Australia, New Zealand (?), the Antarctic, South America, Pacific North America and Greenland (see Kennedy, 1986, 1987 for details).
Subfamily Polyptychoceratinae Matsumoto, 1938.

Genus and Subgenus Phylloptychoceras Spath, 1953.

Type species: Ptychoceras sipho Forbes, 1846, p. 118; by original designation.

Phylloptychoceras (Phylloptychoceras) sp.

P1. 3, fig. 2.

Material: One specimen from the hardground at the top of the Maastrichtian White Chalk at Stevns Klint.

Description: The specimen is $9 \mathrm{~mm}$ long, and consists of two parallel shafts in tight contact, linked by a narrowly curved section, where the two shafts are separated by a tear-shaped opening. The whorl section is circular, and the surface of the internal mould smooth.

Discussion: The shell morphology and lack of ornament of this specimen match that of juvenile Phylloptychoceras sipho (Forbes, 1846) from the Valudayur Group of South India (Forbes, 1846, p. 118 , pl. 11, fig. 5). The specimen is quite different from any other heteromorphs from the Danish Maastrichtian.

Stratigraphy: Upper Maastrichtian stevensischitoniformis brachiopod zone.

Distribution: Stevns Klint only.

Family Baculitidae Gill, 1871.

Genus Baculites Lamarck, 1799.

Type species: Baculites vertebralis (Lamarck, 1801 , p. 103), by subsequent designation by Meek (1876, p. 391).

\section{Baculites knorrianus Desmarest, 1817}

Pl. 13, figs. 12-14.

1817 Baculites knorrianus Desmarest, p. 48, pl. 1, fig. 3.

1979 Baculites knorrianus Desmarest: Birkelund, p. 53.

1987 Baculites knorrianus Desmarest: Kennedy \& Summesberger, p. 32, pl. 4, figs. 4-6; pl. 5 , figs. 1-14; text-fig. 2.

1988 Baculites knorrianus Desmarest, 1817: Vašiček, p. 77, pl. 1, fig. 4; text-fig. 2 .

Type: Neotype, designated by Kennedy \& Summesberger, 1987 , p. 33 , is no. 7459 a in the collec- 
tions of the Naturhistorisches Museum, Vienna (Kennedy \& Summesberger, 1987, pl. 5, figs. 5, $7,8)$.

Locus typicus: Nagoryany, Ukrainian SSR. Stratum typicum: Lower Maastrichtian.

Material: More than 20 specimens, from Rørdal.

Description: All specimens are crushed composite moulds. The shell reaches a very large size, expanding slowly, with whorl heights of up to 65 $\mathrm{mm}$. The whorl section seems to have been very compressed, with somewhat flattened dorsum and narrowly rounded venter. Most specimens are completely smooth. A few show growth striae that are markedly concave on the dorsal half of the flank, sweeping forwards, and markedly prorsiradiate on the ventral half, where they may strengthen into fine narrow riblets that intersect the line of the venter at an acute angle. The suture is complex for Baculites, and specimens are septate to whorl heights of $55 \mathrm{~mm}$.

Discussion: Large size, very compressed whorls, low expansion rate, ornament (where present) and suture complexity show these specimens to belong to Baculites knorrianus. They differ in no significant respects from the large suite of specimens from Nagoryany described by Kennedy and Summesberger (1987). Lack of strong ribbing distinguishes this material from Baculites leopoliensis Nowak, 1908 (p. 328 (pars), pl. 14, figs. 1-5, 10-11; see Kennedy, 1987c, p. 1013, pl. 2, figs. 1, 2, 11, 12; pl. 3, figs. 22-24). Baculites vertebralis Lamarck, 1801 (see revision in Kennedy, 1986b, c, 1987) includes both smooth and ribbed variants, but is much smaller with, when undeformed, a less compressed, more symmetrically oval whorl section. Baculites anceps Lamarck, 1822 (see revision in Kennedy, $1986 \mathrm{~b}, 1987$ ) also includes both ribbed and smooth variants, but is smaller and, when uncrushed, has a characteristic whorl section with broadly rounded dorsum and acute venter.

Stratigraphy: Danish specimens are from the tenuicostata-semiglobularis or semiglobularishumboldti brachiopod zones, spanning the Lower-Upper Maastrichtian boundary. It has been recorded from the Lower Maastrichtian in a broad sense in both North Germany and the USSR. At Nagoryany in the Ukrainian SSR it is dated as Lower Maastrichtian, lanceolate to pseudobtusa belemnite zones.
Distribution: Denmark, Poland, Czechoslovakia, the Ukrainian SSR.

Baculites vertebralis Lamarck, 1801

Pl. 13, figs. 1-11; Pl. 16, figs. 1-5; text-fig. 6A, 8, D-1.

1801 Baculites vertebralis Lamarck, p. 103.

1979 Baculites vertebralis Lamarck: Birkelund, p. 53.

1979 Baculites valognensis Boehm: Birkelund, p. 53.

1986b Baculites vertebralis Lamarck: Kennedy, p. 57 , pl. 11 , figs. $6-11$; pl. 12 , figs. $1-6$; text-figs. 3a-d, 7d-f, 8 (with synonymy).

1987 Baculites vertebralis Lamarck: Kennedy, p. 187 , pl. 19 , figs. $1-4,7-10$; pl. 20 , figs. $3-5$; pl. 28 , figs. $2,7-10,14-16$; pl. 29 , figs. $1-5$; pl. 30 , figs. $1-9$; textfigs. 11a, $b$, 12 (with synonymy).

Type: Lectotype, by subsequent designation by Kennedy, 1986b, p. 57, is the original of FaujasSaint-Fond, 1799, pl. 21, figs. 2, 3.

Locus typicus: Maastricht, The Netherlands.

Stratum typicum: Upper Maastrichtian.

Material: Numerous specimens, from "Dania", Stevns Klint, Kjølby Gård and Bjerre.

Description: The shell is small, and slowly expanding; the largest specimen seen is still septate at a whorl height of $37 \mathrm{~mm}$. The whorl section is compressed, with a whorl breadth to height ratio of 0.67 in the largest specimen seen, and down to 0.55 in smaller specimens. The dorsum is broadly rounded, as are the dorsal flanks; the ventral flanks are convergent and the venter more narrowly rounded than the dorsum, so that the overall section is egg-shaped (Pl. 13, figs. 6,7). Most specimens are smooth, but a few show growth lines and riblets that are concave on the dorsal half of the flanks, projected forwards to intersect the line of the venter at an acute angle. They strengthen markedly on the dorsal part of the flank and over the venter in some specimens. Narrow constrictions are rarely developed (Pl. 13, fig. 11). Suture moderately incised, with rectangular elements (PI. 13, figs. 3, 10).

Discussion: The whorl section distinguishes Baculites vertebralis from $B$. anceps Lamarck, 1822 (see revision in Howarth, 1965, p. 363, pl. 4, fig. 4 ; pl. 5, figs. 4 , 5; pl. 6, figs. $1-5$; text-figs. 2 , 
3, 5-12; Kennedy, 1986b, p. 58, pl. 11, figs. 12-14; pl. 12, figs. 7-11; text-figs. 3e-h, 7a-c), in which the venter is sharp and the overall section tear-shaped. Baculites knorrianus Desmarest, 1817 , described above, is a much larger species, very compressed, and with a much more complicated suture.

Specimens previously identified as Baculites valognensis Boehm (Birkeiund, 1979, p. 53, fig. 1) are here regarded as weakly ornamented variants of $B$. vertebralis (e.g. Pl. 13 figs. 1, 9, 11). $B$. valognensis is based on a small fragment only from Siegsdorf in Oberbayen (Böhm, 1891, p. 50, pl. 1, fig. 13), where it is associated with Hoploscaphites constrictus. It has an ovoid whorl section and weak even riblets, comparing well with the original of Pl. 13, fig. 1. Nowak used the combination Baculites anceps valognensis, but his specimens (1908, pl. 335, pl. 14, figs. 6, 7; text-figs. $1-4$ on p. 331 and $6,7,9,12$ on p. 337) belong to anceps as noted by Howarth (1965) and others. Because of its small size and generalised morphology, valognensis of Böhm should be regarded as a nomen dubium.

Stratigraphy: Danish occurrences are restricted to the stevensis-chitoniformis brachiopod zone, the species extending to the top of the Maastrichtian at Stevns Klint, and to within $20 \mathrm{~cm}$ of the base of the Danian at Kjølby Gård. The species extends lower, into the junior belemnite zone elsewhere in Europe.

Distribution: Widespread in Denmark, also occurring at Limnham, Sweden, in the Maastricht area of The Netherlands and adjacent parts of Belgium, in the Calcaire à Baculites of the Cotentin Peninsula, Manché, France, the Petites Pyrénées (Haute Garonne) in France, Poland, the southern USSR and Tunisia.

\section{Baculites spp.}

Discussion: Birkelund (1979) recorded three other species of Baculites, Baculites sp. 1 from the subtilis-pulchellus brachiopod zone; Baculites sp. 2 from the top of the tenuicostata-semiglobularis and lower part of the semiglobularis-humboldti brachiopod zones; and Baculites sp. 3 from the upper part of the semiglobularis-humboldti zone and lower part of the humboldti-stevensis brachiopod zones. All are small species, but pres- ervation is too poor for identification or illustration.

Superfamily Scaphitaceae Gill, 1871.

Family Scaphitidae Gill, 1871.

Subfamily Scaphitinae Gill, 1871.

Genus Acanthoscaphites Nowak, 1911.

Type species: Scaphites tridens Kner, 1848, p. 10, pl. 2 , fig. 1.

Diagnosis: see Kennedy (1987, p. 204) and Kennedy \& Summesberger (1987, p. 35).

Discussion: Kennedy (1987) and Kennedy \& Summesberger (1987) stress the strongly dimorphic character of this genus. They mainly restrict the genus to the so-called "Acanthoscaphites tridens group", first and foremost described by Nowak (1911) on the basis of material from Nagoryany, now in the Ukrainian SSR. The genus is characterized by very large macroconchs and microconchs of a smaller - but still considerable size. The shape is more evolute than in most scaphites and the body chamber in contact with the phragmocone throughout. Ribs are nearly straight, sometimes intercalated or branching and rather uniformly developed on phragmocone and body chamber. Development of rows of tubercles is highly variable - siphonal tubercles being fairly common. The aperture - at least of microconchs - is characterized by a marked constriction, and the sutures of all species is complex.

On the basis of investigation of museum collections of Acanthoscaphites from Nagoryany, Kennedy (1987) and Kennedy \& Summesberger (1987) reinterpreted most of Nowak's named variants of $A$. tridens (elevated to subspecies or species level by many later authors) as one dimorphic species: $A$. tridens, including, as macroconchs, $A$. tridens (Kner, 1848) $(=A$. trispinosus) (Geinitz, 1850) in litt., see Schmid, 1965 ) and $A$. bispinosus (Nowak, 1911) and as microconchs $A$. trinodosus (Kner, 1848) and $A$. quadrispinosus (Geinitz, 1850).

The stratigraphy of the Nagoryany collections is poorly known. But new investigations of belemnites from museum collections labelled "Nagoryany" indicate the lanceolata to pseudobtusa belemnite zones (sensu Schulz, 1979) based on the occurrence of Belemnella (Pachybelemnella) inflata (Arkhangelsky, 1912) (Christensen, 1987). This age is valid for Acanthoscaphites tridens as defined by Kennedy \& Summesberger (1987) from Nagoryany and is supported by asso- 
ciated nannofossils in the matrix of specimens of the species.

Kennedy \& Summesberger refer very few other species to Acanthoscaphites. The best known is A. varians (Lopuski, 1911), referred to the tridens group by Nowak (1911), but belonging to a higher stratigraphic level than $A$. tridens as now defined (the cimbrica. fastigata and junior, belemnite zones described herein p. 23). They refer $A$. innodosus Naidin, 1974 of the Lower Maastrichtian to Acanthoscaphites (it is probably a phragmocone of a macroconch $A$. tridens), and the Upper Maastrichtian A. verneuilianus (d'Orbigny, 1842).

Birkelund (1982, p. 17, pl. 1, fig. 7) referred a microconch from Hemmoor to a new species, Acanthoscaphites schmidi. The holotype is a small specimen from the junior zone of the Upper Maastrichtian, characterized by two well-developed lateral rows of nodes and a weak siphonal row of nodes on the phragmocone and early part of the body chamber. It was supposed to be related to the considerably younger Scaphites pungens (Binkhorst, 1861), which also has siphonal nodes, and this species was therefore also referred to Acanthoscaphites. Kennedy (1986b) and Kennedy \& Summesberger (1987) considered these two species specialized offshoots of Hoploscaphites constrictus.

The microconch of Acanthoscaphites schmidi shows a rather close resemblance in size and shape to unquestionable microconchs of Acanthoscaphites varians (compare PI. 10, fig. 2), but shows, on the other hand, some resemblance to Hoploscaphites in ribbing of the body chamber. The same applies to possible macroconchs. Knowledge on the macroconchs of both species is required to settle the question.

Blaszkiewicz (1980, p. 38, pl. 19, figs. 2-3, 6-8; pl. 20, figs. 1-3, 6-8; pl. 21, figs. 1-6) described a new species from the Upper Campanian which he referred to the genus Acanthoscaphites: $A$. praequadrispinosus. This species shows close affinity to the genus Jeletzkytes Riccardi, 1983, which includes the so-called Scaphites nodosus group (see Riccardi 1983; Birkelund 1965) of the Upper Campanian, widely distributed in North America and West Greenland, but not well known in Europe.

In conclusion, the genus Acanthoscaphites includes the following well estabiished species: $A$. tridens (including $A$. innodosus), $A$. varians and A. verneuilianus, all from the Maastrichtian of Europe and the USSR. It may be derived from the genus Jeletzkyites Riccardi, 1983 (the "Scaphites nodosus group"), previously referred to Acanthoscaphites by a number of authors (e.g. Nowak, 1916; Reeside, 1928; Cobban \& Reeside, 1952) (see Riccardi, 1983, p. 14)). Riccardi also suggested that a probable connecting link between Jeletzkyites and Acanthoscaphites may be represented by the North American genus Rhaeboceras Meek, 1876.

\section{Acanthoscaphites tridens (Kner, 1848)}

Pl. 8, figs. 2-4; Pl. 9, fig. 2.

1848 Scaphites tridens Kner, p. 10, pl. 2 fig. 1. 1848 Scaphites trinodosus Kner, p. 11, pl. 2, fig. 2.

1979 Acanthoscaphites tridens trinodosa (Kner, 1848): Birkelund, p. 55.

1986a Acanthoscaphites tridens (Kner, 1848): Kennedy, p. 156, fig. 7B, C.

1987 Acanthoscaphites tridens (Kner, 1848): Kennedy, p. 205, pl. 37, figs. 1-5.

1987 Acanthoscaphites tridens (Kner, 1848): Van der Tuuk, p. 61 (pars.) fig. 16a, b.

1987 Acanthoscaphites tridens (Kner, 1848): Kennedy \& Summesberger, p. 36, pl. 4, figs. 1-3; pl. 6, figs. 1-5, 25-28; pl. 7, figs. $1-5$; pl. 8, figs. $1-5$; pl. 9, figs. $1-4$; pl. 10 , figs. $1-2$; pl. 11, figs. $1-2$; pl. 12, figs.1-2; pl. 13 , figs. $1,3,4$; pl. 14 , figs. $1-3$; pl. 15 ; pl. 16, figs. 1-6.

Types: According to Kennedy $(1987$, p. 206) the whereabouts of Kner's material is not known. He proposed that the original of Kner's pl. 2, fig. 1 should be designated lectotype if found.

Locus typicus: Nagoryany, Ukrainian SSR.

Stratum typicum: Lower Maastrichtian.

Material: 4 specimens, all from Møns Klint: 2 microconchs from Hvidskud, 1 macroconch from Hvidskud and 1 macroconch without exact indication of locality.

Description: The material is limited and fragmentary. The best preserved microconch is a body chamber (PI. 9, fig. 2), showing a marked constriction at the aperture, strong siphonal and ventrolateral rows of nodes and a weak row of nodes a third of the distance between the umbil- 
icus and the ventrolateral nodes. The ribs are straight and strong and branch from or intercalate at the level of the inner row of nodes. Another fragment with fairly strong ribs and distant ventrolateral nodes is considered a fragment of a microconch phragmocone (PI. 8, fig. 3).

The phragmocone of a macroconch shown in Pl. 8, fig. 4 shows no nodes and has rather dense, straight, slightly prorsiradiate ribs, branching or intercalating on the flanks. Another fragment of a macroconch (Pl. 8, fig. 2) with earlier parts of the whorls preserved, is finer ribbed.

Discussion: The best preserved microconch, figured in Pl. 9, fig. 2, belongs to the Acanthoscaphites trinodosus type of Kner (1848), described on the basis of material from Nagoryany. It agrees well with other specimens from Nagoryany figured by Nowak (1911, especially pl. 33, figs. 25-26) and by Kennedy \& Summesberger (1987). The best preserved macroconch (Pl. 8, fig. 4) is in good accord with phragmocones of Acanthoscaphites tridens macroconchs from the type area (Kennedy \& Summesberger, 1987).

Stratigraphy: All the Acanthoscaphites tridens specimens here described are from Møns Klint. One of the specimens was collected below the hardground at Hvidskud and thus belongs to the obtusa belemnite zone or, possibly, the lowermost part of the sumensis belemnite zone. Two other fragments are also from Hvidskud, but their stratigraphic level is uncertain.

As mentioned above, the type locality of $A$. tridens at Nagoryany may be referred to the lanceolata to pseudobtusa belemnite zones. Occurrences at Lüneberg (described by Schlüter, 1872, p. 94 , pl. 28 , figs. 1-4) seems to lie in the obtusa belemnite zone (Schulz, 1979, fig. 66). Other occurrences are without exact indication of age, except "the lanceolata zone" or Lower Maastrichtian (e.g. Blaszkiewicz, 1980, p. 40; Naidin, 1974, p. 192; Kennedy, 1987, p. 206; Van der Tuuk, 1987, p. 61).

In summary, the documented stratigraphic range of $A$. tridens seems to be the lower Lower Maastrichtian (the lanceolata, pseudobtusa and obtusa belemnite Zones sensu Schulz, 1979).

Distribution: Denmark; Rugen, German Democratic Repubiic; near Aachen in the German Federal Republic; the Vistula Valley and Miechow Trough, Poland; Ukrainian SSR, Donbass and elsewhere in the southern part of European Russia.

Acanthoscaphites varians (Lopuski, 1911)

P1. 9, figs. 3-7; Pl. 10, figs. 2-3.

1911 Scaphites varians mihi Lopuski, p. 120,137 , pl. 4 , figs. 1-3; text-fig. 4 .

non 1911 Acanthoscaphites tridens-varians Lopuski: Nowak, p. 578, pl. 33, fig. 29.

?1951 Acanthoscaphites tridens (Kner) var. varians (Lopuski): Michailov, p. 104 pl. 16, figs. 72-73.

1965 Acanthoscaphites tridens varians (Lopuski): Schmid, p. 684, pl. 62, fig. 1; pl. 63, figs. 1-3.

1979 Acanthoscaphites tridens varians (Lopuski): Birkelund, p. 55.

1980 Acanthoscaphites varians (Lopuski): Blaszkiewicz, pl. 25, figs. 1-2, 5-6.

1982 Acanthoscaphites varians (Lopuski): Birkelund, p. 16, pl. 1, figs. 4-6.

1988 Acanthoscaphites varians (Lopuski, 1911): Jagt \& Kennedy, p. 238, figs. 1-3.

Holotype: The original of Lopuski, 1911, pl. 4, figs. 1-3, by monotypy (see Blaszkiewicz 1980).

Locus typicus: Kazimierz, Poland.

Stratum typicum: Maastrichtian.

Material: 13 specimens, 7 macroconchs and 3 microconchs from Rørdal (Ålborg) and 3 macroconchs from Hillerslev.

Description: Macroconchs: The material consists of deformed fragments of phragmocones and body chambers. The best preserved specimen (Pl. 10, fig. 3), with phragmocone and early part of body chamber preserved, measures $100 \mathrm{~mm}$ in diameter at the last suture and $160 \mathrm{~mm}$ in total diameter. Other fragments (e.g. Pl. 9, fig. 7) show a similar size at the last suture. The early part of the phragmocone is rather involute, while later parts become more evolute. The sculpture consists of nearly straight, rather coarse primary and secondary ribs and up to 7 or occasionally 9 longitudinal rows of nodes (one siphonal row and 3 or 4 on the flanks). Typically they are developed in radiating rows on primary or secondary ribs. The tuberculate ribs are separated by one or two intercalated nontuberculate ribs. The nodes are well developed on the younger part of the 
phragmocone and on the body chamber to a diameter of about $135 \mathrm{~mm}$. On the youngest parts of the body chamber only the siphonal row and two rows on the outer part of the flanks are well developed; while nodes on the inner parts of the flanks seem to fade out. Poorly preserved sutures show a very incised pattern as in the type specimen (Lopuski, 1911, text-fig. 4).

Microconchs: The three microconchs are characterized by their small size. Diameter at last suture is c. $45 \mathrm{~mm}$ in the largest specimen (Pl. 10, fig. 2). The phragmocones are characterized by ribs similar to those of the macrocochs, and weak nodes. Body chambers have fine ribs and striae and only a single row of fine ventrolateral nodes is visible.

Discussion: Some of the macroconchs here described are larger than Lopuski's type and other specimens from Kazimierz, as figured by Blaszkiewicz (1980, pl. 25, figs. 1-2, 5-6). Specimens figured by Schmid (1965) from Hemmoor are also smaller than Danish material, the greatest whorl width at the last suture-line being $36 \mathrm{~mm}$. It is not, however, possible to tell if the Hemmoor specimens are mature.

In all other characters the specimens described here are very similar to the Hemmoor material described by Schmid (1965) and Birkelund (1982), while the material from Kazimierz differs only in having weaker nodes on the body chamber.

Among other figured specimens, Michailov's (1951) illustration shows only a part of a phragmocone and is not very diagnostic.

Stratigraphy: Specimens from Rørdal and Hillerslev were not collected in situ, but both localities are known to cover the uppermost Lower Maastrichtian and the lowermost Upper Maastrichtian (the tenuicostata - semiglobularis and semiglobularis - humboldtii brachiopod zones). Bed-by-bed collecting at Hemmoor shows that the species in fact occurs both below and above the lower Upper Maastrichtian boundary (from the upper part of the cimbrica zone, through the fastigata zone to the lower part of the junior belemnite zone) in good accordance with the Danish occurrences, as is a recent record from the junior zone in Belgium (Jagt \& Kennedy, 1988).

Polish occurrences at Kazimierz, on the other hand, are claimed to belong to the uppermost part of the Maastrichtian (the so-called Hoploscaphites constrictus crassus zone, see Blaszkiewicz, 1980). If so, the slight difference in morphology noted above may be due to their younger age, and the Kaziemierz specimens may be separated as late forms of $A$. varians, slightly different from the early forms from Germany and Denmark.

Russian occurrences are referred to the middle part of the Maastrichtian without further detail (Mikhailov, 1951).

Occurrence: Denmark, German Federal Republic, German Democratic Republic, Poland, Belgium, and the southern parts of European Russia.

Genus Hoploscaphites Nowak, 1911.

Type species: Ammonites constrictus J. Sowerby, 1817 , p. 189 , pl. A, fig. 1 , by original designation.

Hoploscaphites constrictus (J. Sowerby, 1817)

Pl. 14, figs. 1-7, 12; Pl. 15, figs. 1-14; Pl. 16, figs. 6-16; Pl. 17, figs. 5-23.

1817 Ammonites constrictus J. Sowerby, p. 189, pl. A, fig. 1.

1986 Hoploscaphites constrictus (J. Sowerby, 1817): Kennedy \& Summesberger, p. 198, pl. 16, figs. 1-5, 8-10, 13; text-fig. 7 .

1986b Hoploscaphites constrictus (J. Sowerby, 1817): Kennedy, p. 64, pl. 13, figs. 1-13; 16-24; pl. 14, figs. 1-38; pl. 15; text-figs. 9, 11 a-h (with full synonymy).

1986c Hoploscaphites constrictus (J. Sowerby, 1817): Kennedy, p. 1019, pl. 3, figs. 1, 9-12; pl. 4, figs. $1-19$; pl. 5, figs. $1-17$, 24-26.

1987 Hoploscaphites constrictus (J. Sowerby, 1817): Kennedy, p. 197, pl. 31, figs. 1 , 8-26; pl. 32, figs. 1-12, 18-21.

1987 Hoploscaphites constrictus (J. Sowerby, 1817): Kennedy \& Summesberger, p. 34, pl. 6, figs. 6-24.

1987 Hoploscaphites constrictus (J. Sowerby, 1816): Jagt, p. 1, figs. 1-3.

1987 Hoploscaphites constrictus (J. Sowerby, 1818): Van der Tuuk, p. 64.

1987 Hoploscaphites constrictus constrictus (J. Sowerby, 1818): Van der Tuuk, p. 73, figs. $5,6,7,11,20 a-c, 21 a-c, 23 a-c$.

1987 Hoploscaphites constrictus niedzwiedzkii 
Number of specimens
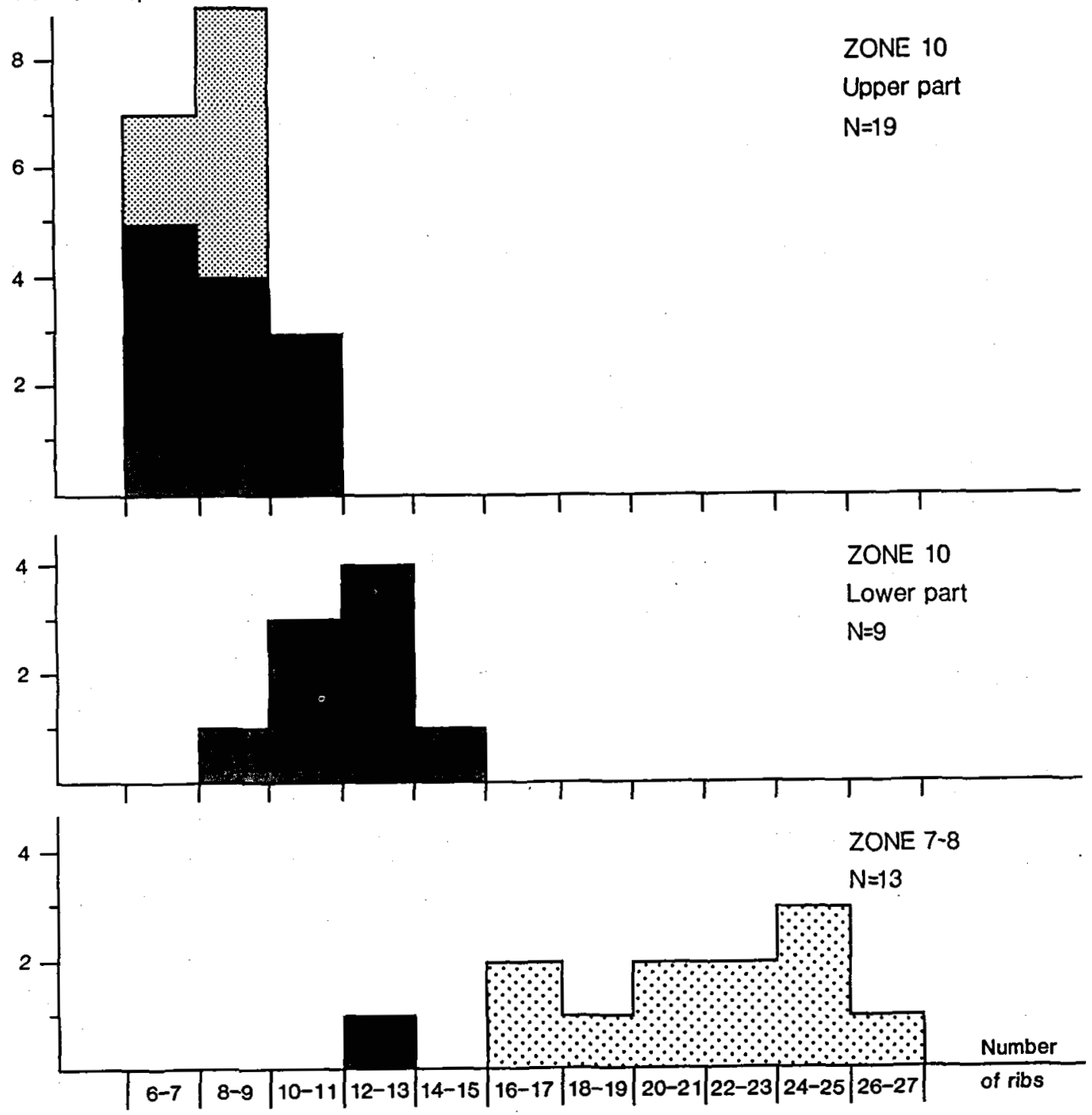

H. constrictus

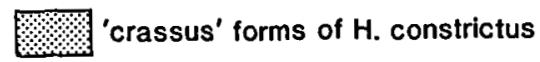

$\therefore$

H. tenuistriatus

Text-fig. 7. Variation in rib density on the body chamber of mature macroconchs of Hoploscaphites. Number of ribs on the last centimetre of the youngest part of the body chamber were measured. Zonal divisions are as in Text-fig. 1.

(Uhlig, 1849): Van der Tuuk, p. 76, figs. 9, $10,24 a-c$.

1987 Hoploscaphites constrictus spp. Indet. Van der Tuuk, p. 77, figs. 8, 25a, b.

1987 Hoploscaphites sp.: Van der Tuuk, p. 77, figs. 4, 17a, b.

1989 Hoploscaphites constrictus (J. Sowerby, 1817): Kennedy, fig. 9a-91.
Lectotype: BMNH C.36733, the original of $\mathrm{J}$. Sowerby, 1817, pl. A, fig. 1. Designated by Kennedy, 1986b, p. 68. Paralectotypes are BMNH C.70645-C.70647.

Locus typicus: Cotentin Peninsula, Manche, France. 
Stratum typicum: Calcaire à Baculites, Upper Maastrichtian.

Material: Several hundred specimens, from many localities, including Aggersund, Ålborg, Batum, Bjerre, "Dania”, Ellidshøj, Erslev, Flødal, Gravlev, Gudumholm, Hillerslev, Hov, Karlstrup, Kjølby Gård, Kongerslev, Lindholm, Mjels, Møn, Rørdal, Rostrup, Skovstrup, Smidie, Stevns Klint, Vive and Voxlev.

Discussion: Hoploscaphites constrictus has been exhaustively described and discussed in recent publications, to which the reader is referred. Birkelund (1982) studied numerous specimens from across the Lower/Upper Maastrichtian boundary at Hemmoor in the German Federal Republic. Kennedy (1986a) revised the type and other material from the Upper Maastrichtian ( $j u$ nior and casimirovensis zones), Calcaire à Baculites of the Cotentin Peninsula; the Upper Maastrichtian (junior and lower casimirovensis zones) of the Maastrichtian type area (1986a, 1987; see Van der Tuuk, 1987, for an alternative interpretation of this fauna); and Upper Maastrichtian of the Petites Pyrénées in southern France (Kennedy, 1986c). Kennedy and Summesberger (1986) described material from the Lower Maastrichtian (approximately sumensis zone sensu Schulz, 1979) of Neuberg, Steiermark, Austria, and Nagoryany in the Ukrainian SSR (1987), dated as Lower Maastrichtian, lanceolata to pseudobtusa zone (sensu Schulz, 1979).

The species is strongly dimorphic (e.g. microconchs, Pl. 15, figs. 4, 5; macroconchs, Pl. 15, figs. 6-14) and there is no reason to treat $H$. constrictus constrictus (based on a macroconch) and the form described as Scaphites niedzwiedzkii Uhlig, 1894 (p. 220, fig. 2) (based on a microconch) as subspecifically distinct, as did Van der Tuuk (1987). It is equally more appropriate to treat Hoploscaphites tenuistriatus (Kner, 1848) as a short-lived species rather than a further subspecies of $\boldsymbol{H}$. constrictus. It differs from the present species in having a relatively coarsely ribbed phragmocone but very finely ribbed body chamber, lacking nodes.

The Hoploscaphites sp. of Van der Tuuk (1987, p. 77 , fig. $4,17 \mathrm{a}, \mathrm{b}$ ) with siphonal tubercles, is from the Upper Maastrichtian of Limburg, The Netherlands, and was thought to be possibly transitional between Hoploscaphites and Acanthoscaphites. But it seems to be no more than a mal- formed $H$. constrictus. This late Maastrichtian material can hardly be transitional between these genera, because they are already present and quite distinct in the early Maastrichtian.

The importance of the Danish material of $H$. constrictus lies in the progressive evolutionary changes they undergo, demonstrated by Birkelund (1979) (Text-figure 7). These changes involve variation in ribbing density, and distribution of nodes on the body chamber. Specimens from the Lower/Upper Maastrichtian boundary (tenuicostata-semigobularis to semiglobularishumboldti zones) have $12-13$ ribs on the last centimetre of body chamber in mature macroconchs. There are 8-15 ribs in specimens from low in the stevensis-chitoniformis zone, and 6-11 in specimens from the upper part of that zone, the mean number shifting markedly (text-fig. 7). Ventral tubercles, present on the early part of the body chamber at all levels, extend progressively further onto the hook and eventually towards the top of the stevensis-chitoniformis zone, to the aperture, in a distinctive variant that has been characterised by some authors as variety crassus Lopuski, 1911. The wide variation in this species can be best appreciated from the illustrations.

Stratigraphy: $H$. constrictus ranges throughout all of the Danish Maastrichtian, to within $20 \mathrm{~cm}$ of the base of the Danian at Kjølby Gård, and is frequent in the top Maastrichtian hardground at Stevns Klint (Pl. 17, figs. 5-9, 11-23). Its lower limit is well documented at Kronsmoor in the German Federal Republic, where it first appears 3.5-5 $\mathrm{m}$ above the base of the Belemnella lanceolata zone. It is rare in the lower part of its range.

Distribution: Denmark, Sweden, the Germanies, The Netherlands, Belgium, France south to the Pyrénées, northern Spain, Czechoslovakia, the Ukraine, Carpathians, Donbass, Transcaspia and Kopet Dag in the USSR, and Bulgaria.

\section{Hoploscaphites tenuistriatus (Kner, 1848)}

P1. 14, figs. 8-11, 13-16.

1848 Scaphites tenuistriatus m. Kner, p. 10, pl. 1, fig. 5.

1987 Hoploscaphites tenuistriatus (Kner, 1848): Kennedy, p. 201, pl. 31, figs. 2-7 (with synonymy).

1987 Hoploscaphites tenuistriatus (Kner, 1848): 
Kennedy and Summesberger, p. 34, pl. 11, fig. 3.

1987 Hoploscaphites constrictus. tenuistriatus (Kner, 1848): Van der Tuuk, p. 72, fig. 19.

1988 Hoploscaphites cf. tenuistriatus (Kner, 1850): Vašiček, p. 78.

Type: Kner's specimen from Lemberg (Lvov) (1848, pl. 1, fig. 5) should be designated lectotype if still in existence.

Locus typicus: Lemberg (Lvov) in the Ukrainian SSR.

Stratum typicum: Lower Maastrichtian.

Material: More than 20 specimens, from Ålborg, Batum, "Danmark", Frejlev, Gudumholm, Hillerslev, Lindholm, Rørdal, Store Taler, Møn and from Rügen in the German Federal Republic.

Description: Specimens are mostly juveniles, or macroconch up to $45 \mathrm{~mm}$ long. The phragmocone is very involute, compressed, with a tiny umbilicus. Ornament varies from coarse to fine, flexuous and prorsiradiate, increasing by branching and intercalation both low and high on the flank. On the body chamber, ornament is of very fine hair-like flexuous prorsiradiate ribs that may arise in bunches at the umbilical shoulder, and increase by branching and intercalation: there are no tubercles on phragmocone or body chamber. The body chamber of macroconchs is high-sided, with straight umbilical wall produced into a bulge at the adapical end that parially obscures the umbilicus.

Discussion: This species is here given full specific rank rather than being treated as a subspecies of $H$. constrictus. The lack of tubercles distinguishes it from all other scaphites in the Danish Maastrichtian.

Stratigraphy: This species ranges from high in the Lower Maastrichtian to low in the Upper: tenuicostatus-semiglobularis to semiglobularishumboldti zones in Denmark, and has a similar range at Hemmoor in the German Federal Republic. The type materiai is probabiy from the lanceolata to pseudobtusa zones (sensu Schulz, 1979) of the Lower Maastrichtian, and most other records are from the Lower Maastrichtian.

Distribution: Denmark, the German Federal Republic, German Democratic Republic, Poland, Czechoslovakia, Limburg, the Netherlands, the Ukrainian SSR, and southern Russia.
Aptychi

Pl. 17, figs. 1-4.

Discussion: Calcitic ammonite jaws occur throughout most of the Danish Maastrichtian. There are two main types. Small rather broad elements, with delicate concentric ribs (PI. 17, figs. 2-4) probably belong to Hoploscaphites constrictus, resembling closely jaws found in situ in Campanian scaphites (e.g. Schlüter, 1871-1876, pl. 23, figs. 10, 11; pl. 25, figs. 5-7; pl. 42, figs. 4 , 5). A second type is larger and more elongated with strong irregular concentric folds (PI. 17, fig. 1). There are no associated ammonites, but they may belong to Pachydiscus.

\section{Dansk sammendrag}

Nitten ammonitarter fra det danske skrivekridt af Maastrichtien alder beskrives og deres stratigrafiske udbredelse diskuteres i relation til zonationer baseret på mikrobrachiopoder og belemniter. Det store ammonitmateriale er indsamlet fra veldefinerede stratigrafiske horisonter fra stort set hele Maastrichtien etagen. De danske skrivekridt ammonitter er således de bedst daterede ammoniter i nordvest Europa. De er af meget stor videnskabelig betydning for biostratigrafi og korrelation og vil udgøre en standard for fremtidig ammonit forskning.

Ammonitter fundet i Danien aflejringer diskuteres og det konkluderes, at de er omlejrede.

\section{References}

Alizade, A., Aliev, G. A., Aliev, M. M., Aliyulla, K. and Khaliev, A. G. 1988. Cretaccous faunas of Azerbaijan. Akad. Nauk. Azerbaidzhanskoi SSR, 454 pp. $26+3+10$ $+8+7+23+19+19+28+8+6$ pls. [In Russian].

Alvarez, L. W., Alvarez, W., Asaro, F. and Michel, H. V. 1980. Extraterrestrial cause for the Cretaceous-Tertiary extinction. Science, 208, 1095-1108.

Arkell, W. J. 1950. A classification of the Jurassic ammonites. J. Paleont., 24, 354-364.

Arkhangelsky, A. 1912. [The Upper Cretaceous deposits in eastern European Russia]. Mater. Geol. Ross., 25, 631 pp., 10 pls. [In Russian].

Binkhorst, J. T. 1861. Monographie des Gastropodes et des Céphalopodes de la Craie Supérieure du Limbourg, $17+83$ pp. (gastropods) +44 pp. (cephalopods), 17 pls. (1-5, 5a, 
$5 \mathrm{a} 1,5 \mathrm{a} 2,5 \mathrm{a} 3,6,5 \mathrm{~b}, 5 \mathrm{c}, 5 \mathrm{~d}, 7,8,8 \mathrm{a}, 9)$ Maastricht, Muquardt; Brussels, Muller Frères.

Birkelund, T. 1957. Upper Cretaceous belemnites from Denmark. Biol. Skr. Dan. Vidensk. Selsk., 9, 1-69.

Birkelund, T. 1965. Ammonites from the Upper Cretaceous of West Greenland. Medd. om Gronl., 179, 192 pp., 42 pls.

Birkelund, T. 1979. The last Maastrichtian ammonites. Pp 51-57 In Cretaceous-Tertiary Boundary Events Symposium, 1, The Maastrichtian and Danian of Denmark, $210 \mathrm{pp}$. Copenhagen, University of Copenhagen.

Birkelund, T. 1982. Maastrichtian ammonites from Hemmoor, Niederelbe (NW Germany). Geol. Jb., A61, 13-33, 3 pls.

Birkelund, T. \& Bromley, R. G. 1979 (Eds.). Cretaceous-Tertiary Boundary events symposium. 1. The Maastrichtian and Danian of Denmark. 210 pp. Copenhagen, University of Copenhagen.

Birkelund, T. \& Håkansson, E. 1982. The terminal Cretaceous extinction in Boreal Shelf seas - A multicausal event. Geol. Soc. Amer. Spec. Pap., 190, 373-384.

Blaszkiewicz, A. 1980. Campanian and Maastrichtian ammonites of the Middle Vistula Valley, Poland: a stratigraphicpaleontologic study. Pr. Inst. geol., 92. 1-63, 56 pls.

Böhm, J. 1891. Die Kreidebildung des Fürbergs und Sulzbergs bei Siegsdorf in Oberbayern. Palaeontographica, 38, 1106 , pls. 1-5.

Bromley, R. G. 1967. Some observations on burrows of thalassinidean Crustacea in chalk hardgrounds. $Q . \mathrm{Jl}$. geol. Soc. London., 123, 157-182.

Bromley. R. G. 1968. Burrows and borings in hardgrounds. Meddr Dansk geol. Foren., 18, 247-250.

Bromley, R. G. 1975. Trace fossils at omission surfaces. Pp. 399-428 In Frey, R. W. (Ed.) The Study of Trace-Fossils. New York. Springer Verlag.

Christensen, W.K. 1979. Maastrichtian belemnites from Denmark. Pp. 42-44 In Cretaceous-Tertiary Boundary Events Symposium. 1. The Maastrichtian and Danian of Denmark. 210 pp. Copenhagen, University of Copenhagen.

Christensen, W. K. 1987. Belemnella (Pachybelemnella) inflata (Arkhangelsky) from Nagoryany, USSR. Beitr. Paläont. Österr., 13, 79-84.

Christensen, W. K. 1988. Upper Cretaceous belemnites of Europe: state of the art. Pp. 1-16 In Streel, M. and Bless, M. J. M. The Chalk District of the Euregio Meuse-Rhine. Selected papers on the Upper Cretaceous. Naturhistorisch Museum, Maastricht, Liège University.

Christensen, L., Fregerslev, S., Simonsen, A. \& Thiede, J. 1973. Sedimentology and depositional environment of Lower Danian Fish Clay from Stevns Klint, Denmark. Bull. geol. Soc. Denmark, 22, 192-212.

Cobban, W. A. \& Reeside, J. B. Jr. 1952. Correlation of the Cretaceous formations of the Western Interior of the United States. Bull. Geol. Soc. Am., 63, 1011-1043.

Collignon, M. 1956. Ammonites néocrétaces du Menabe (Madagascar) IV. Les Phylloceratidae. Annls géol. Serv. Mines Madagascar, 23, 5-37, pls. 1-4.

Collignon, M. 1971. Atlas des fossiles caractéristiques de Madagascar (Ammonites) XVII (Maestrichtien), iv +44 pp., pls. 640-658. Tananarive, Service Géologique.

Defrance, M. J. L. 1816. Dictionnaire des Sciences naturelles, dans lequel on traité méthodiquement des différents Etres de la Nature ... 1816-1830, 60 vols. text, 12 vols. plates, vol. 3 (1816), 492 pp. + 174 pp. In supplément. Plates - Zoologie, Conchyliologie et Malacologie, by H. M. D. de Blainville, 1816-1830, 36 pp., 118 pls. Paris, Strasbourg, Levrault.

Desmarest, A. G. 1817. Mémoire sur deux genres coquilles fossiles cloisonnées et à siphon. J. Phys. Chim. Hist. nat., $85,42-51$, pls. $1,2$.

Diener, C. 1925. Ammonoidea neocretacea. Fossilium Cat. (1: Animalia), 29, $244 \mathrm{pp}$
Faujas-Saint-Fond, B. [1799]. Histoire naturelle de la montagne de Saint-Pierre de Maëstricht, 263 p., 53 pls. Paris, H. J. Jansen.

Favre, E. 1869. Description des Mollusques fossiles de la Craie des environs de Lemberg en Galicie, xii xii +187 pp. 13 pls. Geneva, H. Georg.

Forbes A. 1846. Report on the fossil Invertebrata from southern India, collected by Mr. Kaye and Mr. Cunliffe. Trans. geol. Soc. Lond. (2) 7, 97-174, pls. 7-19.

Geinitz, H. B. 1849-1850. Das Quadersandsteingebirge oder Kreidegebirge in Deutschland. 293 pp., 12 pls., Freiberg. Craz and Gerlach.

Giers, R. 1964. Die Grossfauna der Mukronatenkreide (unteres Obercampan) im östlichen Münsterland. Fortschr. Geol. Rheinh. u. Westf., 7, 213-294, 8 pls.

Gill, T. 1871. Arrangement of the Families of Mollusks. Smith son, misc. Collns., 227, xvi +49 pp.

Grossouvre, A. de. 1894. Recherches sur la craie supérieure, 2: Paléontologie. Les ammonites de la craie supérieure. Mém. Serv. Carte géol. dêt. Fr., 264 pp., 39 pls. (misdated 1893).

Grossouvre, A. de. 1908. Description des ammonites du Crétacé Supéricur du Limbourg Belge et Hollandais et du Hainaut. Mém. Mus. r. Hist. nat. Belg., 4, 1-39, pls. 1-11.

Haczewski, G. \& Szymakowska, F. 1985. Znaleziko amonita Saghalinites wrighti Birkelund w kredzie jednostki magurskie. Kwartalnik Geologiczny, 28, 649-654, pl, 1.

Håkansson, E. \& Hansen, J. M. 1979. Guide to Maastrichtian and Danian boundary strata in Jylland. Pp. 171-188 In Cretaceous-Tertiary Boundary Events Symposium. 1. The Maastrichtian and Danian of Denmark. 210 pp. Copenhagen, University of Copenhagen.

Hansen, J. M. 1979. Dinoflagellate zonation around the boundary. Pp. 136-141 In Cretaceous-Tertiary Boundary Events Symposium. 1. The Maastrichtian and Danian of Denmark. 210 pp. Copenhagen, University of Copenhagen.

Hansen, H. J. 1990. Diachronous extinctions at the K/T boundary; a scenario. Geol. Soc. Amer. Spec. Pap., 247, 417423.

Hansen, H. J. Gwozdz, R., Hansen, J. M., Bromley, R. G. \& Rasmussen, K. L. 1986. The diachronous CiT plankton extinction in the Danish Basin. Lecture Notes in Earth Sciences 8, 381-384. Berlin, Heidelberg, Springer-Verlag.

Hansen, H. J., Gwozdz, R., \& Rasmussen, K. L. 1988. Highresolution trace element chemistry across the Teriary-Cretaceous boundary in Denmark. Revta. Espanol.-Paleont. Numero Extraordinario, 21-29.

Hansen, H. J., Rasmussen, K. L., Gwozdz, R. \& Kunzendorf, H. 1986. Iridium-bearing Carbon Black at the CretaceousTeriary boundary.Bull. geol. Soc. Denmark, 36, 305-314.

Hauer, F von, 1858. Ueber die Cephalopoden der Gosauschichten. Beitr. Paläont. Österr., 1, 7-14, pls. 2-4.

Heinberg, C. 1976. Bivalves from the White Chalk (Maastrichtian) of Denmark, I: Limopsidae. Bull. geol. Soc. Denmark, 25, 57-70.

Heinberg, C. 1979a. Bivalves from the White Chalk (Maastrichtian) of Denmark, II: Arcoida. Bull. geol. Soc. Denmark, 27, 105-116.

Heinberg, C. $1979 \mathrm{~b}$. Bivalves from the latest Maastrichtian of Stevns Klint and their stratigraphic affinities. Pp. 58-64 In Cretaceous-Tertiary Boundary Events Symposium. 1. The Maastrichtian and Danian of Denmark. 210 pp. Copenhagen, University of Copenhagen.

Heinberg, C. 1980. Evolutionary ecology of nine sympatric species of the pelecypod Limopsis in Cretaceous chalk. Lethaia, 12, 325-340.

Henderson, R. A. \& McNamara, K. A. 1985. Maastrichtian non-heteromorph ammonites from the Miria Formation, Western Australia. Palaeontology, 28, 35-88, pls. 1-9. 
Hoepen, E. C. N. van, 1921. Cretaceous Cephalopoda from Pondoland. Ann. Transv. Mus., 7, 142-147, pls. 24-26.

Howarth, M. K. 1965. Cretaceous ammonites and nautiloids from Angola. Bull. Br. Mus. nat. Hist. (Geol)., 10, 335412,13 pls.

Hyatt, A. 1889. Genesis of the Arietidae. Smithson. Contr. Knowl., 673, xi +238 pp., 14 pls.

Hyatt, A. 1900. Cephalopoda, pp. 502-604, in Zittel, K. A. Von, 1896-1900, Textbook of Palaeontology, transl. Eastman, C. R., London and New York, Macmillan.

Immel, H., Klinger, H. C. \& Wiedmann, J. 1982. Die Cephalopoden des Unteren Santon der Gosau von Brandenberg/ Tirol, Öesterreich. Zitteliana, 8, 3-32, 11 pls.

Jagt, J. M. W. 1987. Hoploscaphites constrictus (J. Sowerby, 1817). Meded. Rijks Geol. Dienst., 41-2, 1-5.

Jagt, J. M. W. \& Kennedy, W. J. 1988. Acanthoscaphites varians (Lopuski, 1911) (Ammonoidea) from the Upper Maastrichtian of Haccourt, Belgium. Geol. Mijnb., 68, 237-240.

Kennedy, W. J. 1986a. The Campanian-Maastrichtian ammonite sequence in the environs of Maastricht (Limburg, the Netherlands). Newsl. Stratigr., 16, 149-168.

Kennedy, W. J. 1986b. The ammonite fauna of the Calcaire à Baculites (Upper Maastrichtian) of the Cotentin Peninsula (Manche, France). Palaeontology, 29, 25-83, pls. 1-16.

Kennedy, W. J. 1986c. In, Kennedy, W. J., Bilotte, M., Lépicard, B. \& Segura, F., Upper Campanian and Mastrichtian ammonites from the Petites-Pyrénées, southern France. Eclogae geol. Helv., 79, 1001-1037, 5 pls.

Kennedy, W. J. 1987. The ammonite faunas of the type Maastrichtian, with a revision of Ammonites colligatus Binkhorst, 1861. Bull. Inst. r. Sci. nat. Belg., 56, 151-267, 37 pls.

Kennedy, W. J. 1989. Thoughts on the evolution and extinction of Cretaceous ammonites. Proc. Geol. Ass., 100, 251-279.

Kennedy, W. J. \& Klinger, H. C. 1977a. Cretaceous faunas from Zululand and Natal, South Africa. The ammonite family Phylloceratidae. Bull. Br. Mus. nat. Hist. (Geol.), 27, (5), 349-380, 15 pls.

Kennedy, W. J. \& Klinger, H. C. 1977b. Cretaceous faunas from Zululand and Natal, South Africa. The ammonite family Tetragonitidae Hyatt, 1900. Ann. S. Afr. Mus., 73, 149-197.

Kennedy, W. J. \& Klinger, H. C. 1979. Cretaceous faunas from Zululand and Natal, South Africa. The ammonite family Gaudryceratidae. Bull. Br.Mus. nat. Hist. (Geol.), 31, (2), 121-174, 14 pls.

Kennedy, W. J. \& Summesberger, H. 1984. Upper Campanian ammonites from the Gschliefgraben (Ultra-helvetic, Upper Austria). Beitr. Paläont. Österr., 11, 149-206, pls. 1-14.

Kennedy, W. J. \& Summesberger, H. 1986. Lower Maastrichtian ammonites from Neuberg, Steiermark, Austria. Beitr. Paläont. Österr., 12, 181-242, 16 pls.

Kennedy, W. J. \& Summesberger, H. 1987. Lower Maastrichtian Ammonites from Nagoryany (Ukrainian SSR). Beitr. Paläont. Österr., 13, 25-78, pls. 1-16.

Kner, R. 1848. Versteinerungen des Kreidemergels von Lemberg und seiner Umgebung. Haidingers naturwiss. Abh., 2, $1-42,5$ pls.

Kossmat, F. 1895-1898. Untersuchungen über die süd-indische Kreideformation. Beitr. Paläont. Oest.-Ung., 9, (1895): 97-203 (1-107), pls. 15-25 (1-11); 11, (1897a): 1-46 (108153), pls. 1-8 (12-19); 11. (1898): 89-152 (154217), pls. 14-19 (20-25).

Lamarck, J. P. B. A. de M. de. 1799. Prodrome d'une nouvelle classification des coquilles. Mém Soc. Hist. nat. Paris, for 1799, 63-90.

Lamarck, J. P. B. A. de M. de. 1801. Système des Animaux sans vertebrès. vii +432 pp. Paris, The Author, Deterville.
Lamarck, J. P. B. A. de M. de. 1822. Histoire naturelle des Animaux sans vertebrès, 7, $711 \mathrm{pp}$. Paris, Verdière.

Lopuski, C. 1911. Przyczynki do znajmosci fauny kredowej gubernii. Lubelskiej, I. C. R. Séanc. Soc. Sci. Varsovie, 4, 104-110, pls. 1-4.

Macellari, C. 1986. Late Campanian-Maastrichtian ammonite fauna from Seymour Island (Antarctic Peninsula). Mem. Paleont. Soc., 18, 55 pp.

Matsumoto, T. 1938. A biostratigraphic study on the Cretaceous deposits of the Naibuchi Valley. South Karahuto. Proc. Imp. Acad. Japan, 14, 190-194.

Matsumoto, T. 1959. Upper Cretaceous Ammonites of California. Part 11. Mem. Fac. Sci. Kyushu Univ., ser. D. Geol., Special Volume, 1, 172 pp., 41 pls.

Matsumoto, T. \& Morozumi, Y. 1980. Late Cretaceous ammonites from the Izumi Mountains; southwest Japan. Bull. Osaka Mus. Nat. Hist., 33, 1-31, pls. 1-16.

Meek, F. B. 1857. Descriptions of new organic remains from the Cretaceous rocks of Vancouver Island. Trans. Albany Inst., 4, 37-49.

Meek, F. B. 1876. A report on the inverebrate Cretaceous and Tertiary fossils of the upper Missouri country. In Hayden, F. V., Report of the United States Geological Survey of the Territories, 9, Ixiv + 629 pp., 45 pls.

Mikhailov, N. P. 1951. [Upper Cretaceous ammonites from the southern part of european Russia and their importance for zonal stratigraphy (Campanian, Maastrichtian)]. Trudy Inst. geol. Nauk. Akad. Nauk, SSSR., 129, (Geol. ser. 50), 143 pp., 19 pls. [In Russian].

Moberg J. C. 1885. Cephalopoderna i Sveriges Kritsystem. II. Sver. geol. Unders. Afh., C, 73, 1-63, pls. 1-4.

Naidin, D. P. 1974. [Ammonoidea] Pp. 158-195, pls. 53-70. In Krymgolts, G. Ja. (Ed.), [Atlas of Upper Cretaceous fauna of Donbass]. Moscow, "Nedra" [In Russian].

Nowak, J. 1908. Untersuchungen über Cephalopoden der Oberen Kreide in Polen. I. Teil, Genus Baculites. Bull. int. Acad. Sci. Lett. Cracovie. Cl. Sci. math. nat., B, for 1908 , 326-353, pl. 14.

Nowak, J. 1911. Untersuchungen über die Cephalopoden der oberen Krejde in Polen. II. Teil, Die Skaphiten. Bull. int. Acad. Sci. Lett. Cracovie Cl. Sci. math. nat, (B) for 1911, $547-589$, pls. $32,33$.

Nowak, J. 1913. Untersuchungen über die Cephalopoden der oberen Kreide in Polen. III. Teil. Bull. int. Acad. Sci. Lett. Cracovie Cl. Sci. math. nat., (B) for 1913, 335-415, pls. 40-45.

Nowak, J. 1916. Zur Bedeutung von Scaphites für die Gliederung der Oberkreide. Verhandl. geol. Reichsanst. (St. Anst-Landesanst). Wien for 1916, 55-67.

Obradovich, J. D. \& Cobban, W. A. 1975. A time scale for the Late Cretaceous of the Western Interior of North America. Geol. Assoc. Canada Special Pub., Pap. 13, 431-454.

Orbigny, A. d'. 1840-1842. Paléontologie française: Terrains crétacés, 1, Céphalopodes, 1-120 (1840); 121-430 (1841); 431-662 (1842), $148+3$ pls., Paris, Masson.

Owen, D.D., 1852. Geological Survey of Wisconsin, Iowa and Minnesota, and incidentally a portion of Nebraska Territory: made under the direction of the US Treasury Department, Philadelphia. 195 pp., 29 pls + maps + sections. Philadelphia, Lippincott, Grambo \& Co.

Ravn, J. P. J. 1902-3. Molluskerne i Danmarks Kritaflejringr. K. Dansk Vidensk. Skr., 6 Rk., nat. og mat. Afd. 11, 1, Lamellibranchiater, 73(5)-138(70), pls. 1-4 (1902); 2, Scaphopoder, Gastropoder og Cephalopoder, 209(5)-269(65), pls. 1-5 (1902); 3, Stratigrafisker undersøgelser, 339(5)433(99), 1 pl. (1903).

Redtenbacher, A. 1873. Die Cephalopodenfauna der Gosauschichten in den nordöstlichen Alpen. Abh. K.-K. geol. Reichanst., 5, 91-140, pls. 22-30.

Reeside, J. B. 1928. The Scaphites, an Upper Cretaceous am- 
monite group. Prof. Pap. U.S. geol. Surv., 150B, 21-36, pls. 9-11.

Riccardi, A. C. 1983. Scaphitids from the Upper CampanianLower Maastrichtian Bearpaw Formation of the Western Interior of Canada. Bull. geol. Surv. Can., 354, 103 pp., 26 pls.

Rosenkrantz, A. 1924. Nye Iagttagelser over Cerithium kalken i Stevns Klint med Bemaerkninger om Graensen mellem Kridt og Tertiaer. Meddr. dansk Geol. Foren., 6, Møder og Ekskursioner, 28-31.

Rosenkrantz, A. 1966. Die Senon/Dan Grenze in Dänemark. Ber. dt. Ges. Geol. Wiss., A (Geol. Paläont.), 11, 721-727.

Salfeld, H. [J. C. A]. 1924. Die Bedeutung der Konservativ. stämme für die Stammesentwicklung der Ammonoiden. 16 pp.; 16 pls., Leipzig.

Schlüter, C. 1871-1876. Cephalopoden der oberen deutschen Kreide. Palaeontographica, 21, 1-24, pls. 1-8 (1871); 21, 25-120, pls. 9-35 (1872); 24, 1-144 (121-264) + x, pls. 36-55 (1876).

Schmid, F. 1962. Exkursionsbericht. Die Kreide am Zeltberg bei Lüneberg. Pal. Zeitschr., 36, 3-5.

Schmid, F. 1965. Acanthoscaphites tridens varians (Lopuski, 1911) aus dem Maastricht von Hemmoor (Niederelbe) in Nordwest-Deutschland. Geol. $J b ., 83,681-692,2$ pls.

Schulz, M. G. 1979. Morphometrisch-variationsstatistische Untersuchungen zur Phylogenie der Belemniten - Gattung Belemnella im Untermaastricht NW Europas. - Geol. Jb., A47, 3-157, 12 pls.

Schulz, M. G., Ernst, G., Ernst, H. \& Schmid, F. 1984. Coniacian to Maastrichtian stage boundaries in the standard section for the Upper Cretaceous White Chalk of NW Germany (Lagerdorf-Kronsmoor-Hemmoor): definitions and proposals. Bull. geol. Soc. Denmark, 33, 203-215.

Schulz, M. G. \& Schmid, F. 1983. Das Ober-Maastricht von Hemmoor (N-Deutschland): Faunenzonen Gliederung und Korrelationen mit dem Ober-Maastricht von Dänemark und Limburg. Newsl. Stratigr., 13, 21-39.

Seunes, J. 1890. Contributions à l'étude des céphalopodes du Crétacé Supérieur de France. 1. Ammonites du Calcaire à Baculites du Cotentin. Mém. Soc. géol. Fr. Paléont., 1, Mém. 2, 1-7, pls. 2-3 (1-2).

Shimizu, S. 1934. [Ammonites]. In Shimizu, S. \& Obata, T. /Cephalopoda. Iwanami's lecture series of Geology and Palaeontology]. 137 pp., [Tokyo: In Japanese].

Shinn, E. A. 1969. Submarine lithification of Holocene carbonate sediments in the Persian Gulf. Sedimentology, 12, 109 144.

Smit, J. \& Ten Kate, W. G. H. Z. 1982. Trace-element patterns at the Cretaceous-Tertiary Boundary - consequences of a large impact. Cret. Res., 3, 307-332.

Sowerby, J. 1817. The Mineral Conchology of Great Britain, 2, pls. 151-184, A, 185, 186. London, The Author.

Spath, L. F. 1922. On the Senonian ammonite fauna of Pondoland. Trans. R. Soc. S. Afr, 10, 113-147, pls. 5-9.

Spath, L. F. 1925. On Senonian Ammonoidea from Jamaica. Geol. Mag., 62, 28-32, pl. 1.

Spath, L. F. 1926. On new ammonites from the English Chalk. Geal. Mag., 63, 77-83, table.

Spath, L. F. 1953. The Upper Cretaceous Cephalopod fauna of Grahamland. Scient. Rep. Br. Antarct. Surv., 3, 1-60, pls. 1-13.

Stanton, T. W. 1896. Contribution to the Cretaceous palaeontology of the Pacific Coast. The fauna of the Knoxville Beds. Bull. US geol. Surv., 133, 1-132, pls. 1-10 (1895 imprint).

Steinmann, G. 1895. Die Cephalopoden der QuiriquinaSchichten. Neues Jb. Miner. Geol. Paläont. Beilbd., 10, 64-94, pls. 4-6.

Stinnisbeck, W. 1987. Zu den faunistischen und paläontologischen verhältnissen in der Ouiriquina Formation
(Maastrichtium) Zentral-Chiles. Palaeontographica, 194A 99-237, 16 pls

Stoliczka, F. 1863-1866. The fossil cephalopoda of southern India. Ammonitidae with revision of the Nautilidae \& $\mathbf{c}$ Mem. geol. Surv. India (1), Palaeonit. indica, 3, (1), 41-56, pls. 26-31 (1863); (2-5), 57-106, pls. 32-54 (1964); (6-9), $107-154$, pls. $55-80$ (1865); (10-13), 155-216, pls. $81-94$ (1866).

Surlyk, F. 1969. A study of the articulate brachiopods of the Danish White Chalk (U. Campanian and Maastrichtian) with a review of the sedimentology of the White Chalk and the fauna and flora of the Chalk Sea. Unpublished Thesis, University of Copenhagen, $319 \mathrm{pp}$.

Surlyk, F. 1970. Die Stratigraphie des Maastricht von Dänemark und Norddeutschland aufgrund von Brachiopoden. Newsl. Stratigr., 1, 7-16.

Surlyk, F. 1972. Morphological adaptations and population structures of the Danish Chalk brachiopods (Maastrichtian, Upper Cretaceous). Biol. Skr. Dan. Vid. Selsk., 19, 57 pp., 5 pls.

Surlyk, F. 1979a. Maastrichtian brachiopods from Denmark. Pp. 45-50 In Cretaceous-Tertiary Boundary Events Symposium, 1, The Maastrichtian and Danian of Denmark. 210 pp. Copenhagen, University of Copenhagen.

Surlyk, F. 1979b. Guide to Stevns Klint. Pp. 164-170 In Cretaceous-Tertiary Boundary Events Symposium. 1. The Maastrichtian and Danian of Denmark. 210 pp. Copenhagen, University of Copenhagen.

Surlyk, F. 1982. Brachiopods from the Campanian-Maastrichtian boundary sequence, Kronsmoor (NW Germany). Geol. Jb., A61, 259-277.

Surlyk, F. 1984. The Maastrichtian Stage in NW Europe, and its brachiopod zonation. Bull. geol. Soc. Denmark, 33, 217223.

Svendsen, N. 1975. Carbonat sedimentologiske Studier af to profiler på Stevns Klint $300 \mathrm{~m}$ nord for Højerup Kirke. Unoublished Thesis, University of Copenhagen, $76 \mathrm{pp}$.

Thomsen, E. 1976. Depositional environment and development of Danian bryozoan biomicrite mounds (Karlby Klint, Denmark). Sedimentology, 23, 485-509.

Thomsen, E. 1977. Phenetic variability and functional morphology of erect cheilostome bryozoans from the Danian (Palaeocene) of Denmark. Paleobiol., 3, 360-376.

Tuuk, L. van der, 1987. Scaphitidae (Ammonoidea) from the Upper Cretaceous of Limburg the Netherlands. Pal. Zeitschr., 61, 57-79.

Uhlig, V. 1984. Bemerkungen zu Gliederung karpathischer Bildung. Jb. K. - K. geol. Reichsanst. Wien, 44, 215-222.

Vašiček, Z. 1988. Die Oberkreide-Ammoniten (Maastricht) aus dem Abteufen des Einziehschachts der Grube Stał̌ič (Unterschlesische Decke, Ảussere Karpaten). Acta. Mus. Moraviae. Sci. nat., 73, 71-87, 1 pl.

Wiedmann, J. 1966. Stammesgeschichte und System der posttriadischen Ammonoideen: ein Uberblick. Neues Jb. Geol. Paläont. $A b h$., 125, 49-79, pls. 1-2; 127, 13-81, pls. 3-6.

Wiedmann, J. 1969. The heteromorphs and ammonoid extinction. Biol. Rev., 44, 563-602.

Wisniowski, T. 1907. Uber die Obersenone Flyschfauna von Leszczyny. Beitr. Paläont. Geol. Oëst.-Ung., 30, 191-205. pl. 17.

Wollemann, A. 1902. Die Fauna der Lüneburger Kreide. $A b h$. preuss. geol. Landesanst., N.F. 37, 111 pp., 7 pls.

Wolansky, D. 1932. Die Cephalopoden und Lamellibranchiaten der Ober-Kreide Pommerns. Abh. Geol. Paläont. Inst. Univ. Greifswald, 9, 72 pp., 5 pls.

Wright, C. W. \& Kennedy, W. J. 1984. The Ammonoidea of the Lower Chalk, Par 1. Palaeontogr. Soc. (Monogr.), 1-126, pls. $1-40$.

Wright, C. W. \& Matsumoto, T. 1954. Some doubtful Cretace- 
ous ammonite genera from Japan and Saghalien. Mem. Fac. Sci. Kyushu Univ. (D). Geol., 4, 107-134, pls. 7-8.

Yabe, H. 1921. In Yabe, H. \& Shimizu, S. 1921, Notes on some Cretaceous ammonites from Japan and California. Sci. Rep. Tohoku Imp. Univ. (2), 5, 53-59, pls. 8-9.

Yabe, H. \& Shimizu, S. 1926. A study on the genus "Parapachydiscus". Proc. Imp. Acad. Japan. 2, 171-173.
Zittel, K. A. von, 1884. Handbuch der Palaeontologie... Abt. 1, 2, (Lief. 3), Cephalopoda, 329-522. Munich and Leipzig, R. Oldenburg.

Zittel K. A. von 1895. Grundzüge der Palaeontologie (Palaeozoologie), vii +972 pp. Munich and Leipzig. R. Oldenbourg. 


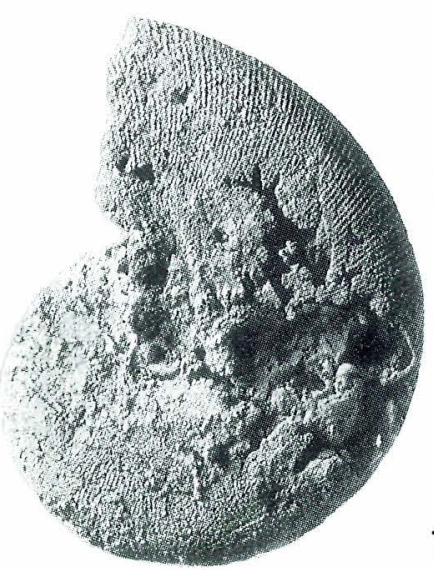

1a
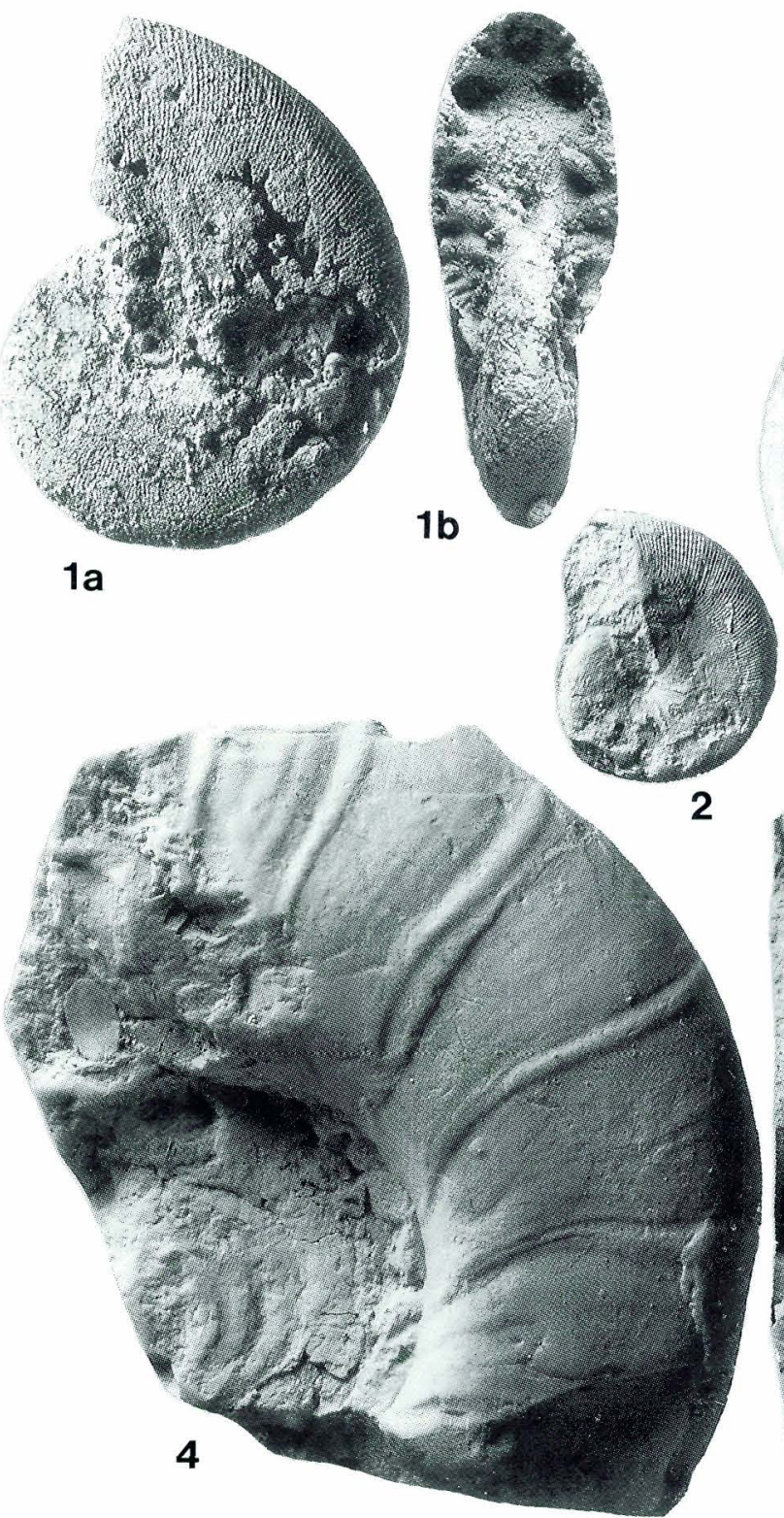
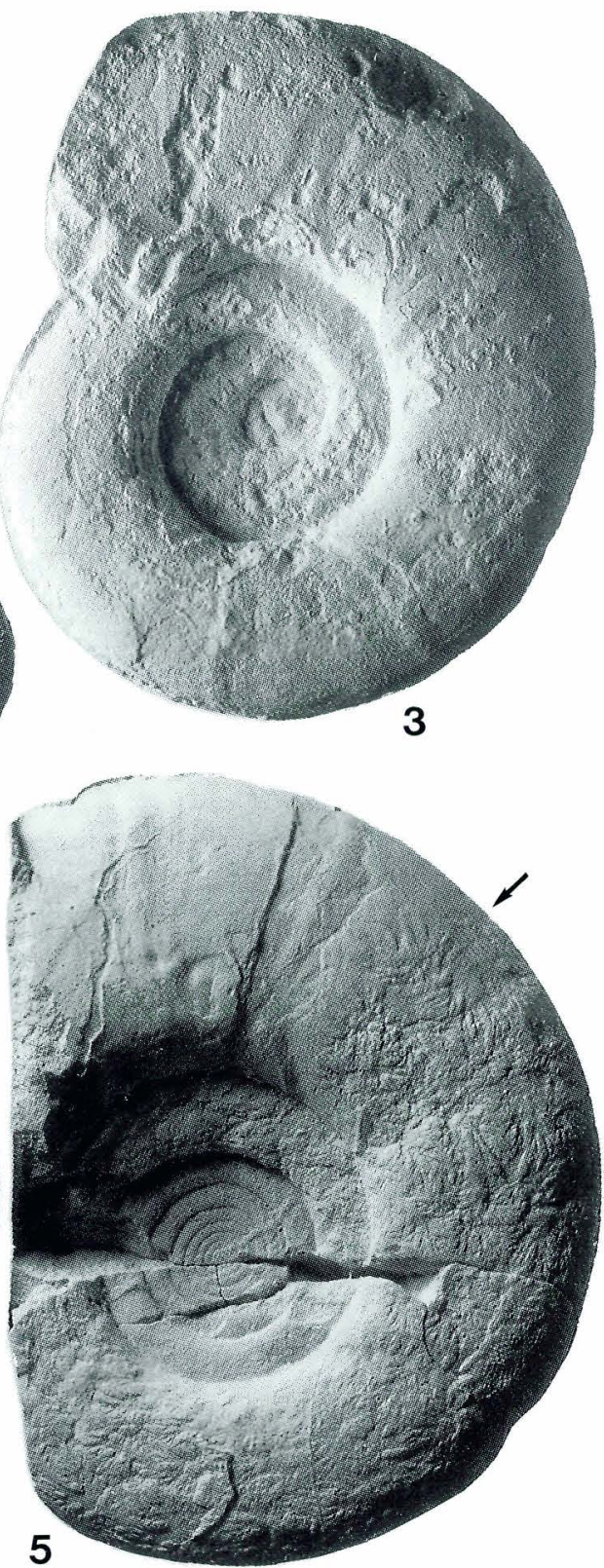

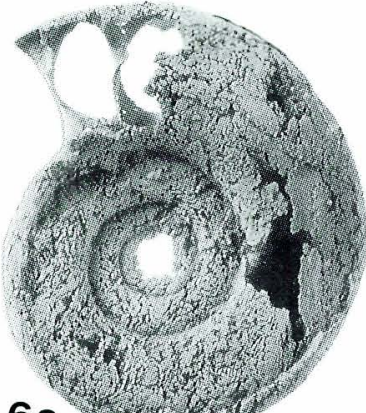

$6 a$
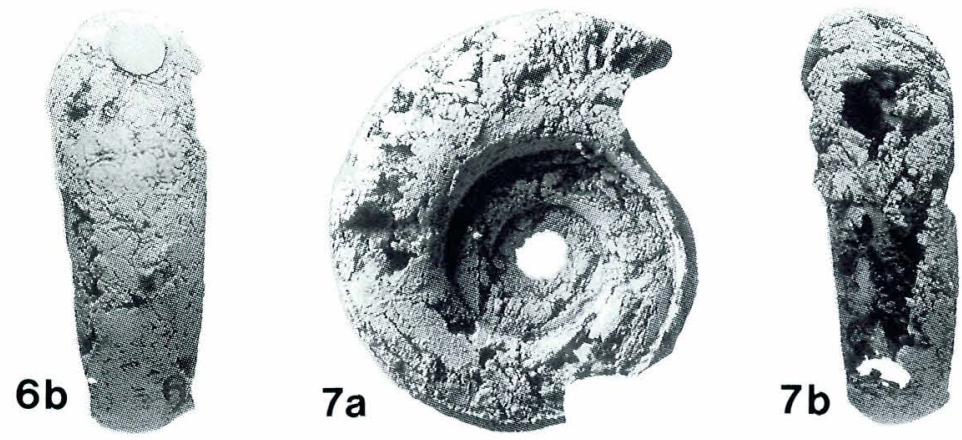

PLATE 1 (All figures are $\times 1$ ).

Figs. 1-2. Hypophylloceras (Neophylloceras) velledaforme (Schlüter, 1872). 1a-b: Silicified phragmocone, Ålborg, exact locality unknown, MGUH 20090. 2: Phragmocone, "Dania", MGUH 20091.

Figs. 3-5. Anagaudryceras lueneburgense (Schlüter, 1872). 3: Phragmocone, Rørdal, Ålborg. MGUH 20092. 4: Crushed inner whorls and phragmocone with fine lirae preserved, Frejlev. MGUH 20093. 5: Phragmocone and part of body chamber, Rørdal, Ålborg. MGUH 20094.

Figs. 6-7. Saghalinites wrighti Birkelund, 1965. 6a-b: Silicified phragmocone, Frejlev; figured by Schlüter, 1872, Pl. 7, figs. 6-7 (as Ammonites n. sp.?). MGUH 1520. 7a-b: Silicified phragmocone, Frejlev. MGUH 20095. 

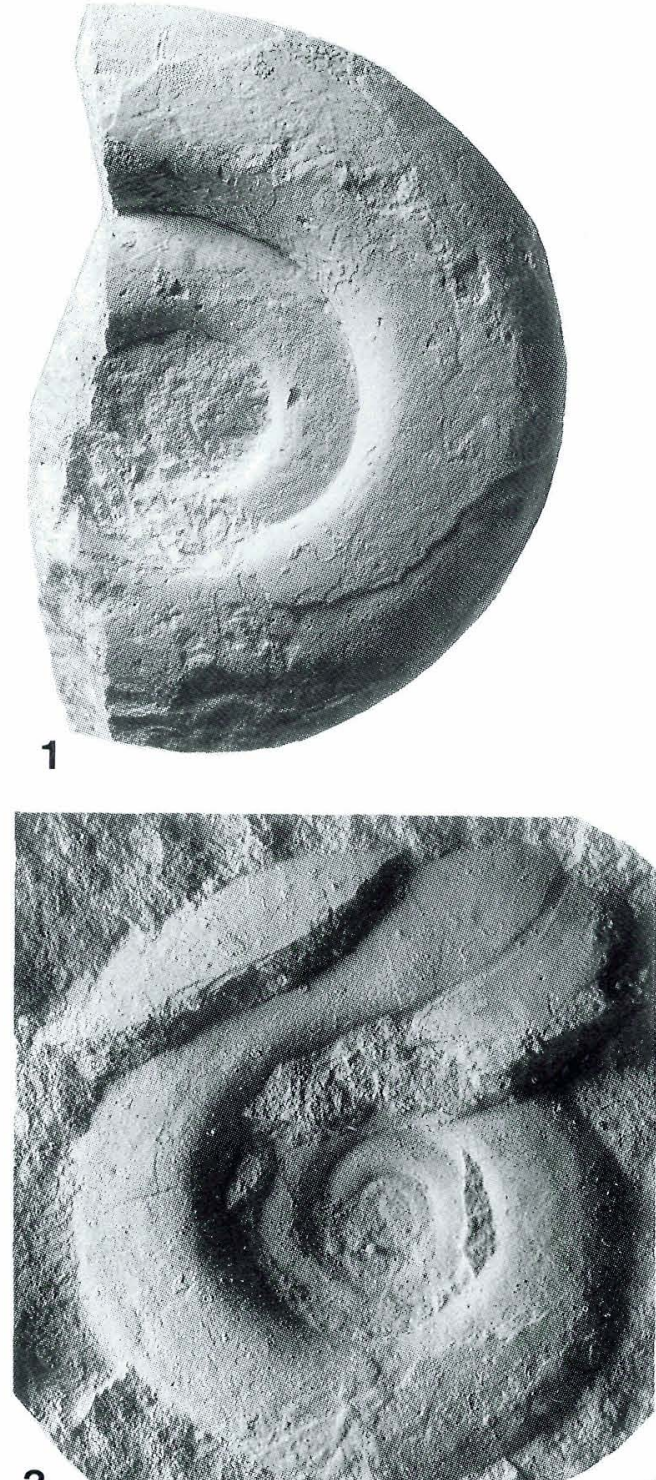

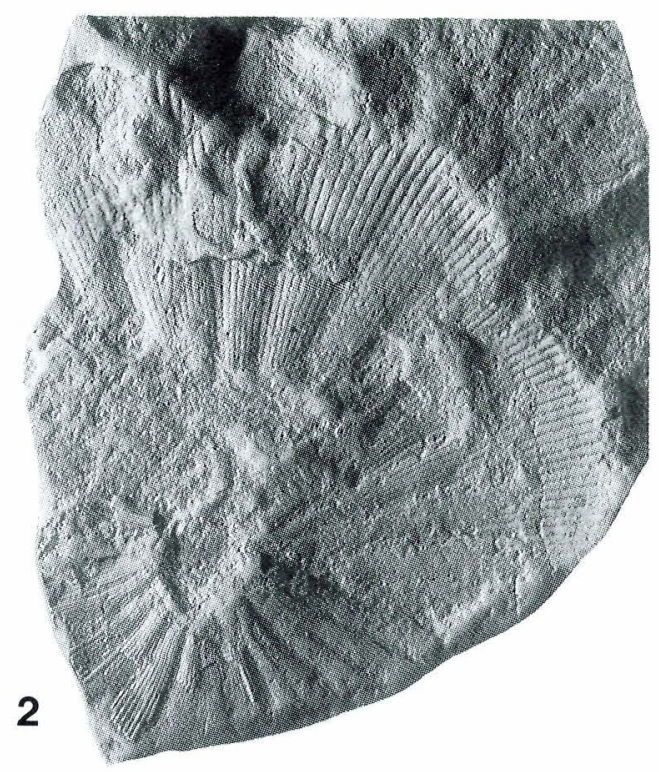

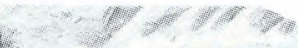

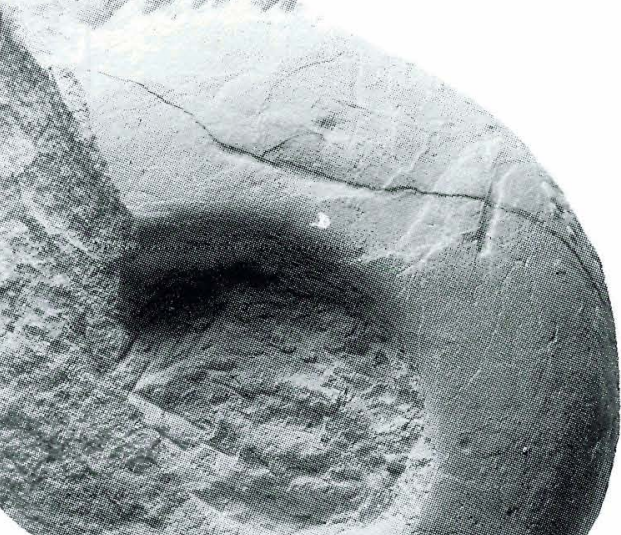

4

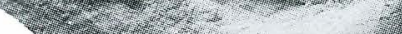

\section{3}
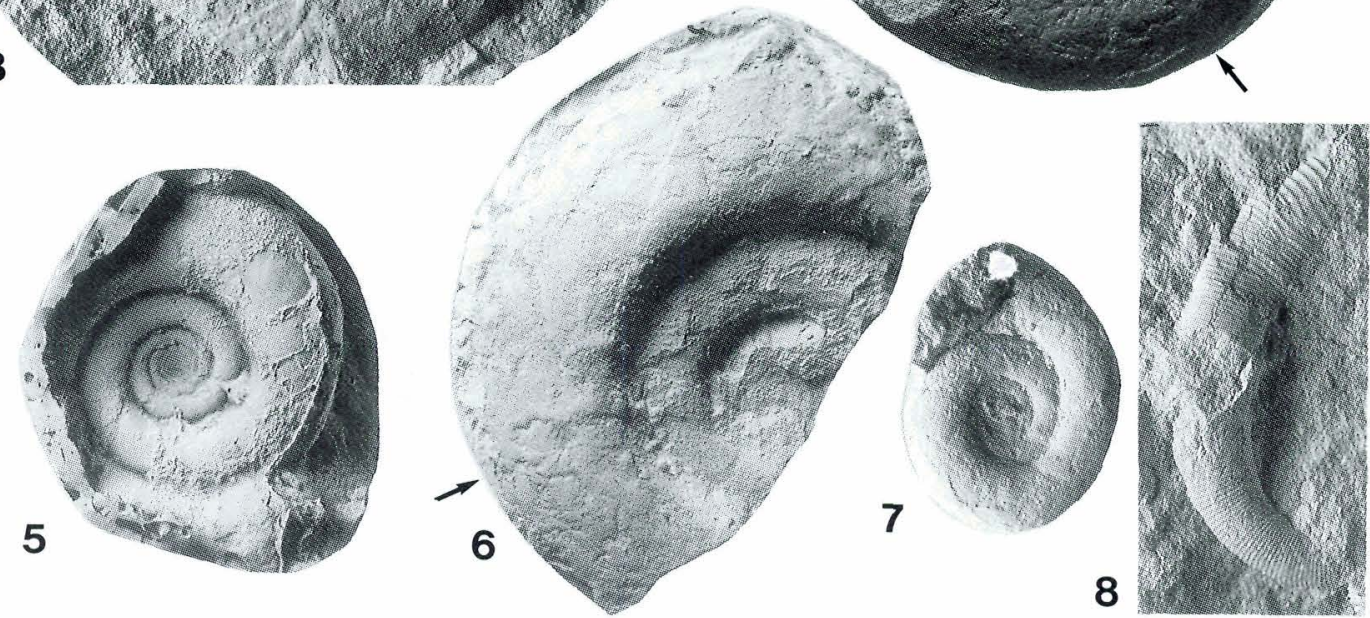

PLATE 2 (All figures are $\times 1$ ).

Figs. 1, 3, 4, 6: Saghalinites wrighti Birkelund, 1965. 1: Phragmocone with most of body chamber preserved, "Danmark", Alborg, MGUH 20096. 3: Composite mould of complete specimen with constriction at the aperture, Hillerslev, MGUH 20097. 4: Part of phragmocone with suture lines and most of body chamber preserved, Rørdal, Ålborg, MGUH 2009. 6: Part of the phragmocone and early part of body chamber preserved, Hillerslev, MGUH 20099.

Fig. 2. Hypophylloceras (Neophylloceras) surya (Forbes, 1846 Composite mould, "Dania", MGUH 20100.

Fig. 5. Saghalinites n. sp. Original of de Grossouvre, 1908, Pl. 10, fig. 5. Kunrade, The Netherlands.

Fig. 7. Saghalinites n. sp. No suture lines preserved. Bjerre, MGUH 20101.

Fig. 8. Glyptoxoceras cf. tenuisulcatum (Forbes, 1846). Hillerslev, MGUH 20102. 


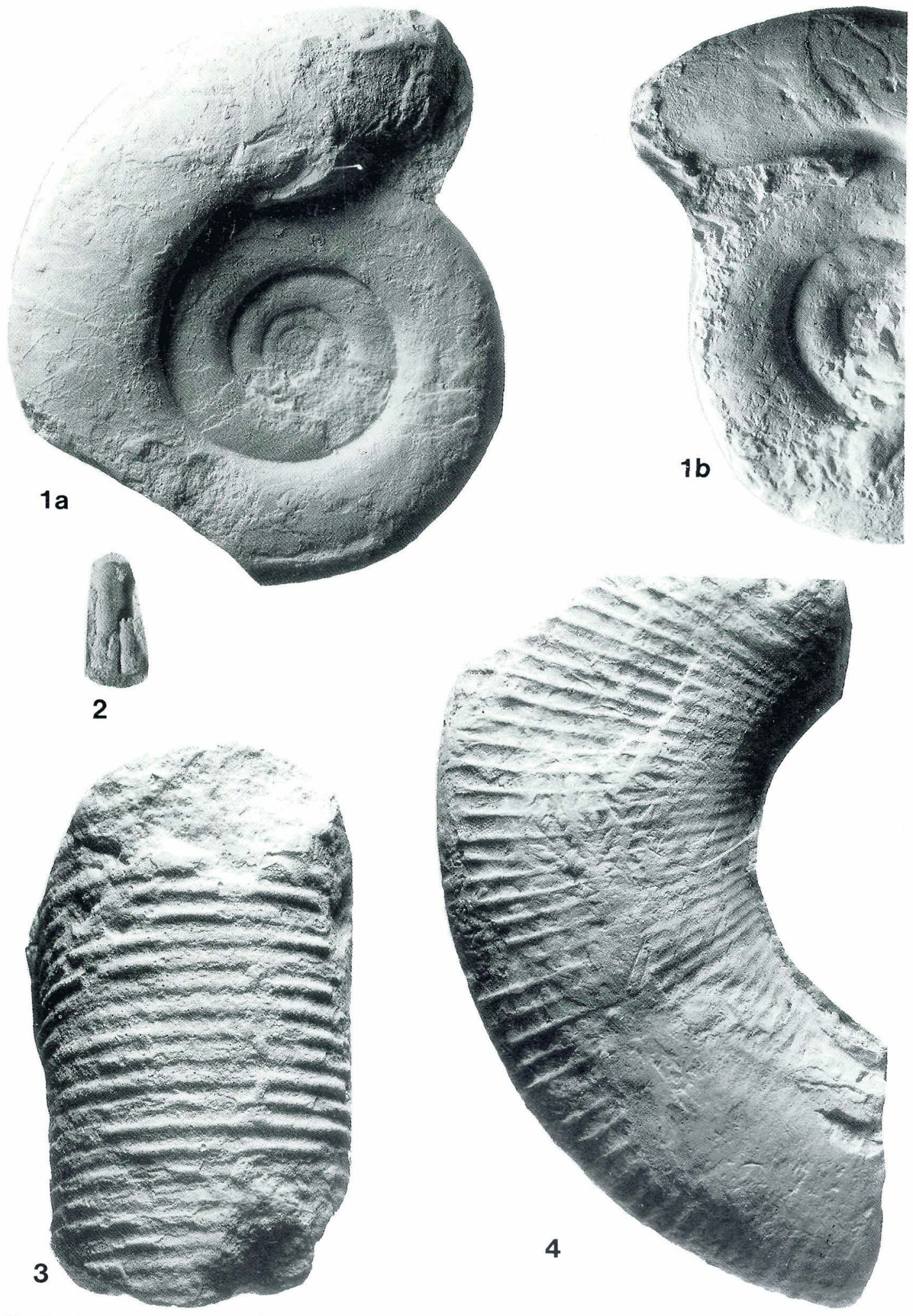

PLATE 3 (Figs. 1,3 and 4 are $\times 1$; Fig. 2 is $\times 2$ ).

Figs 1a-b: Saghalifites n. sp. Complete specimen with constriction at aperture (visible in Ib). Hov, MGUH 20103.

Fig. 2 Phylloptychoceras (Phylloptychoceras) sp. Stevns Klint in hardground immediately below the Danian, MGUH 20104.

Figs. 3-4. Diplomoceras cylindraceum (Defrance, 1816). 3: Møns Klint, MGUH 20105. 4: Frejlev, MGUH 20106. 

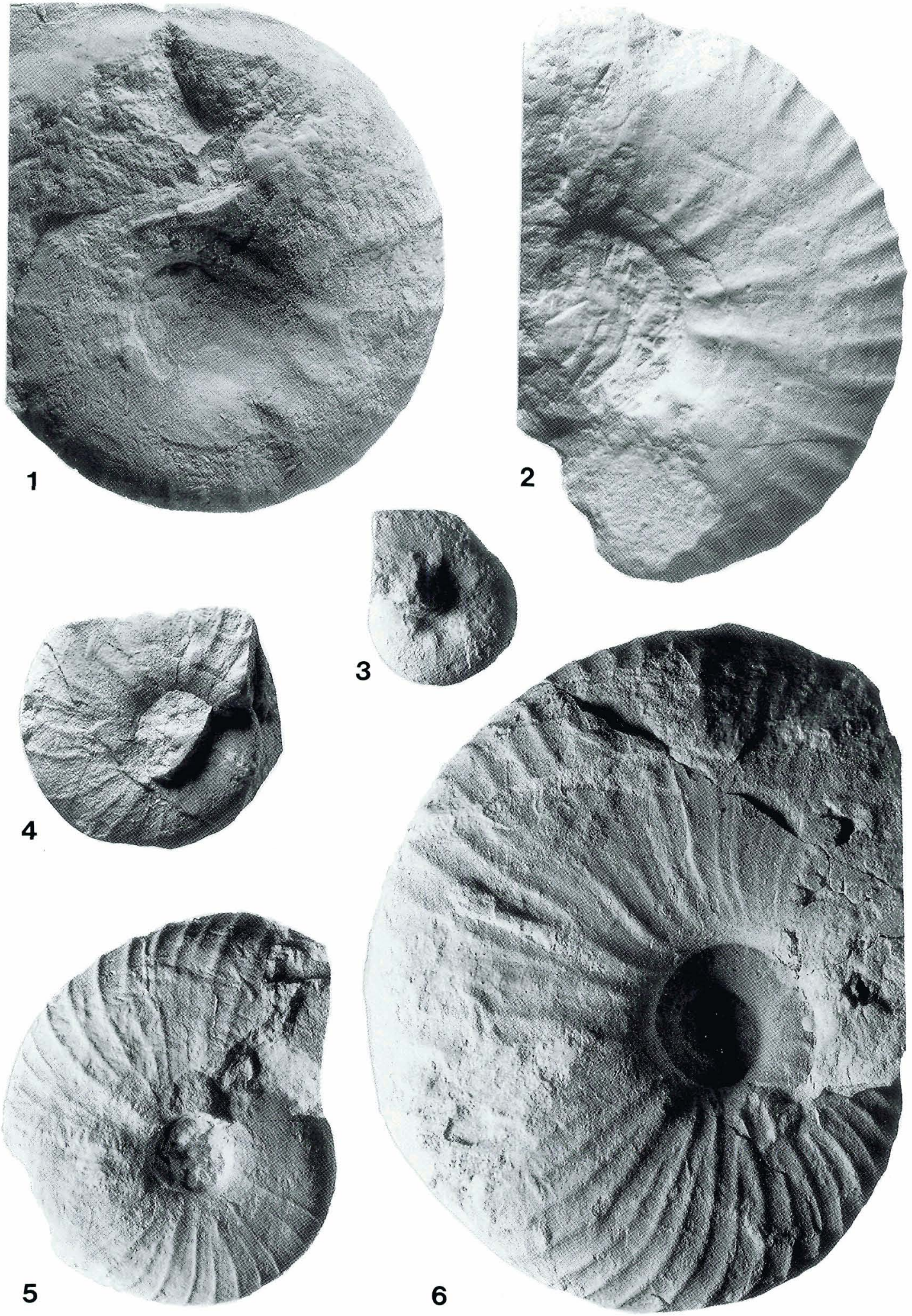

PLATE 4 (All figures $\times 1$ ).

Figs. 1-2: Pachydiscus (Pachydiscus) neubergicus (von Hauer, 1858). 1: Phragmocone, Rørdal, Ålborg, MGUH 20107. 2: Fragment, Hillerslev, MGUH 20108.

Figs. 3-5: Anapachydiscus aff. fresvillensis (Seunes, 1890). 3: Inner whorls showing weak thickening of the ribs at umbilicus, Stevns Klint, hardground immediately below the Danian, MGUH 20109. 4: Phragmocone, Stevns Klint, south of Højerup, MGUH 20110. 5-6: Phragmocones, "Dania", MGUH 20111-12. 


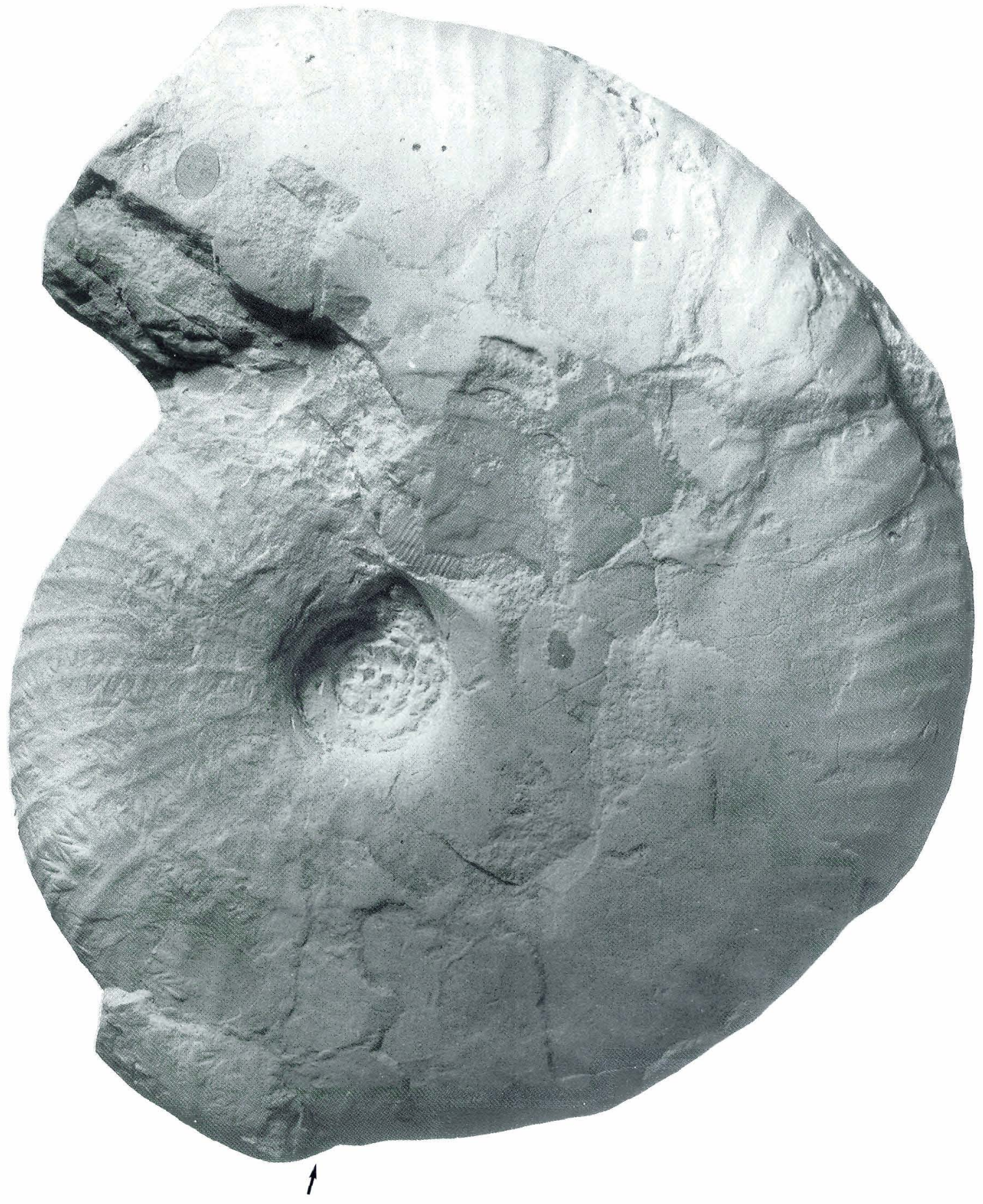

PLATE 5 (Figure is $\times 1$ ).

Anapachydiscus aff. fresvillensis (Seunes, 1890). Nearly complete specimen with most of body chamber preserved. "Dania", MGUH 20113. 


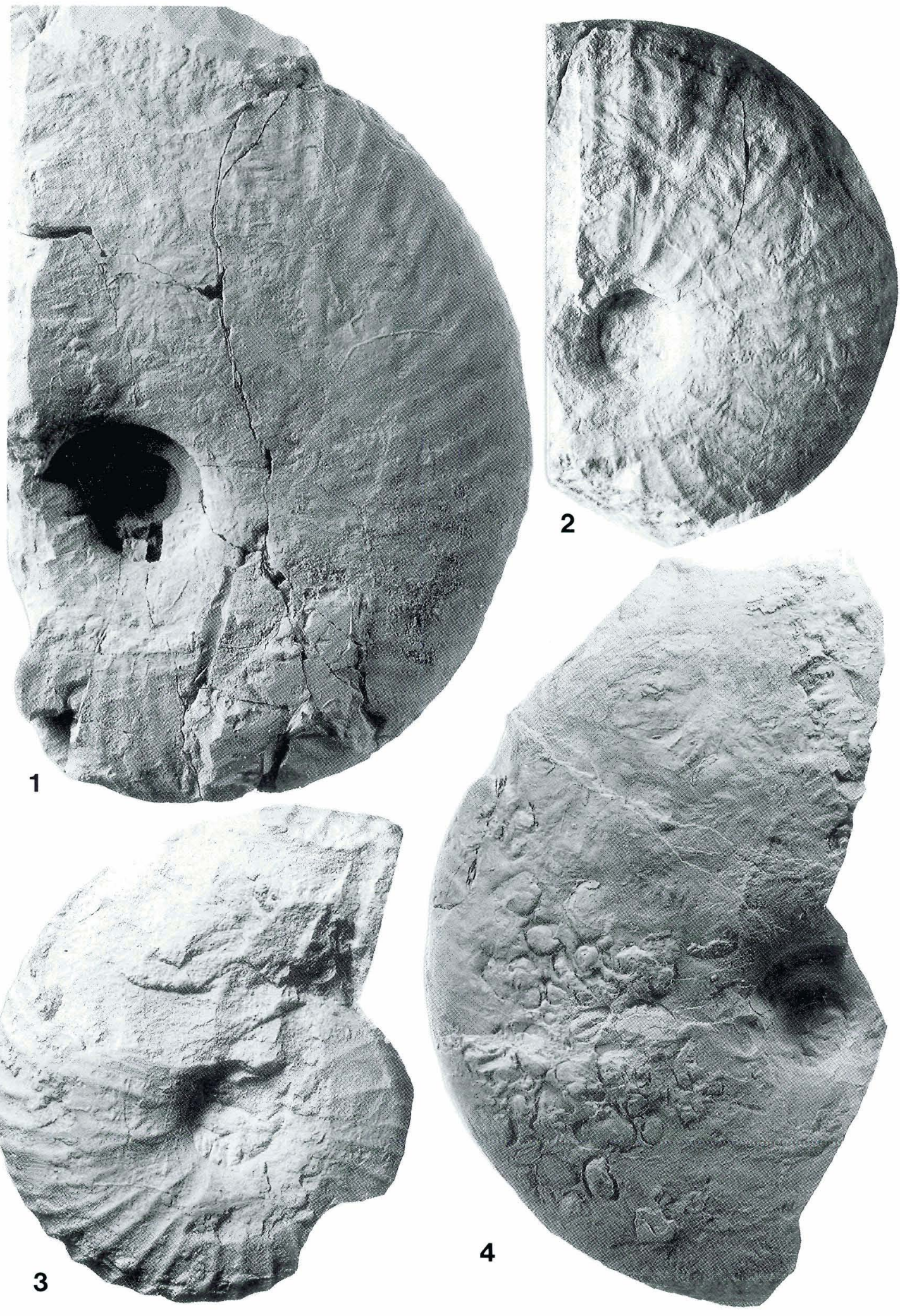

PLATE 6 (Figs. $1-3$ are $\times 1$; Fig. 4 is $\times 0.5$.

Figs. 1-4. Anapachydiscus aff. fresvillensis (Seunes, 1890). "Dania". All phragmocones, 4: overgrown by oysters. MGUH 20114 20117. 


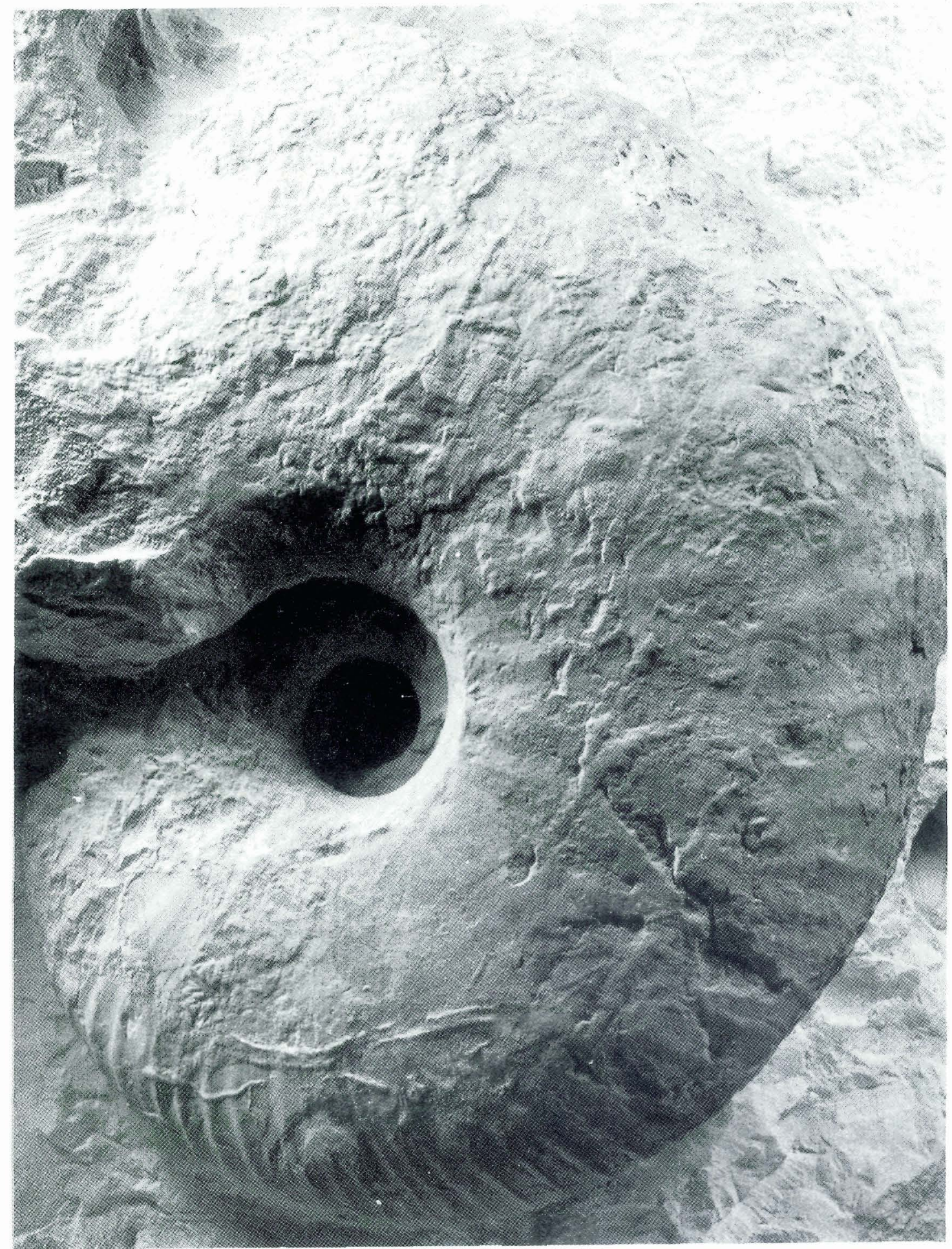

PLATE 7.

Anapachydiscus aff. fresvillensis (Seunes, 1890). "Dania". MGUH 20118. Reduced $\times 0.8$. 

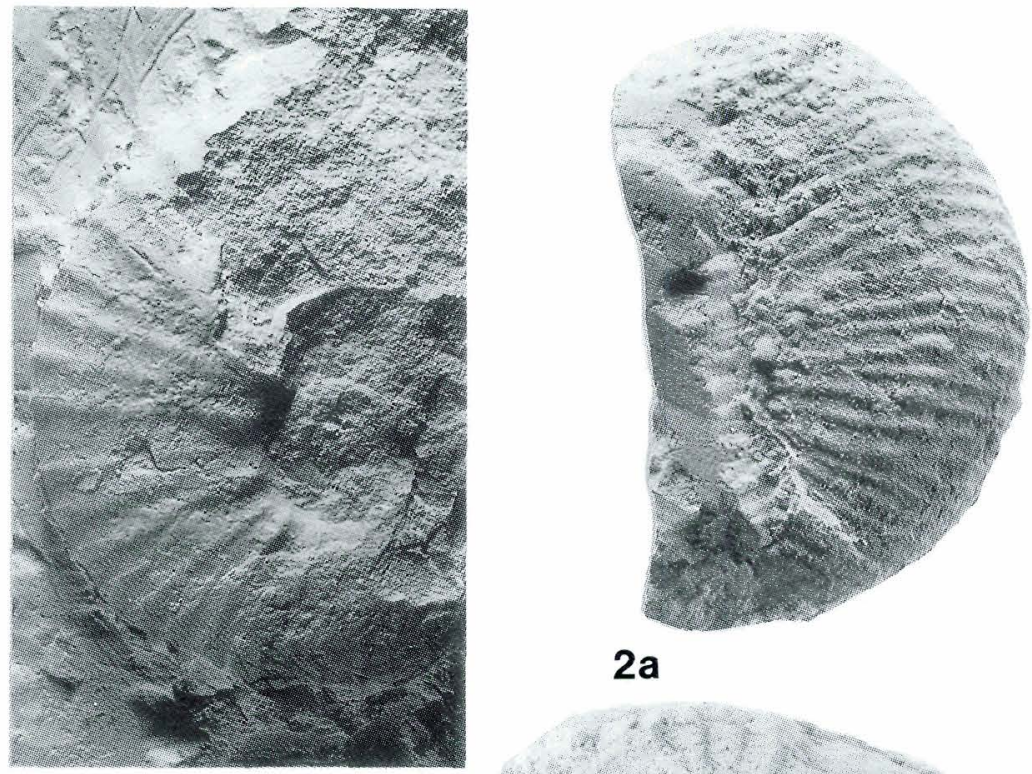

2a

1

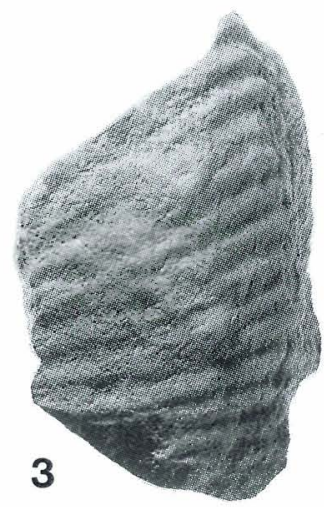

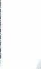
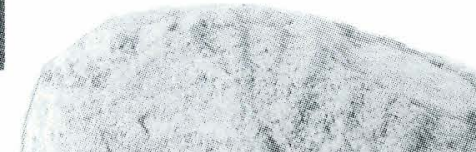

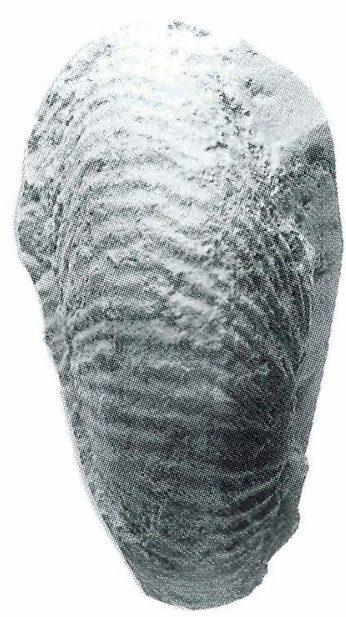

2b

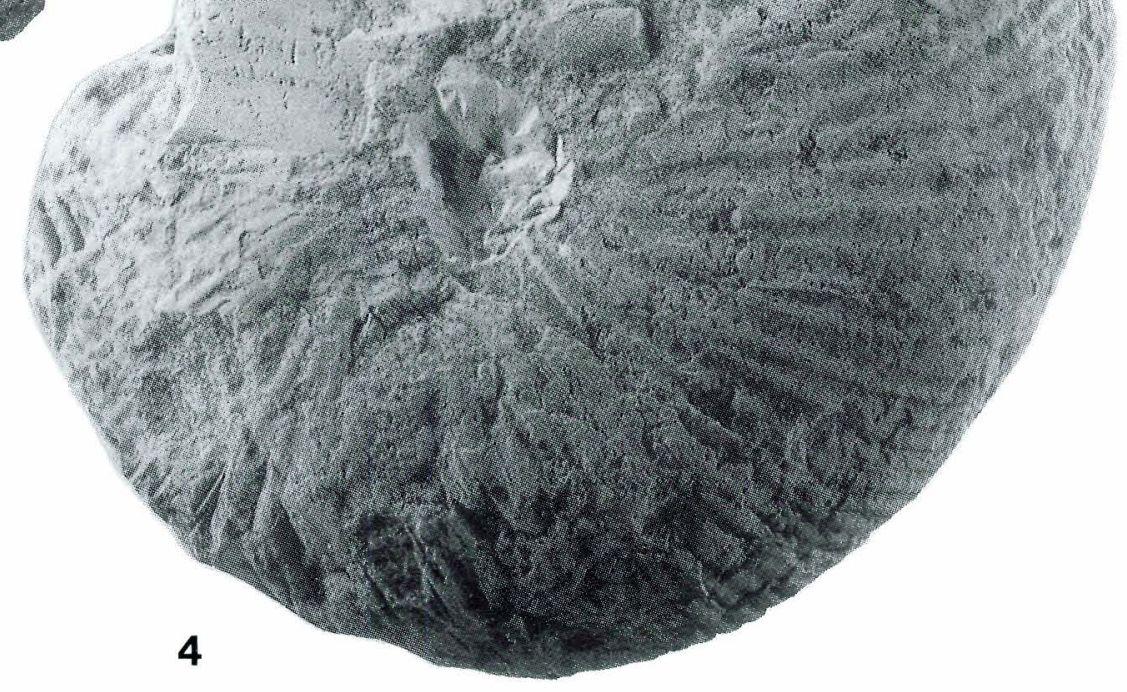

PLATE 8 (All figures are $\times 1$ ).

Fig. 1. Pachydiscus (Pachydiscus) neubergeicus (von Hauer, 1858), Lindholm, MGUH 20119.

Figs. 2-4. Acanthoscaphites tridens (Kner, 1848). 2-3: Hvidskud; 2 is MGUH 20120, 3 is MGUH 20121. 4: Møn, MGUH 20122. 


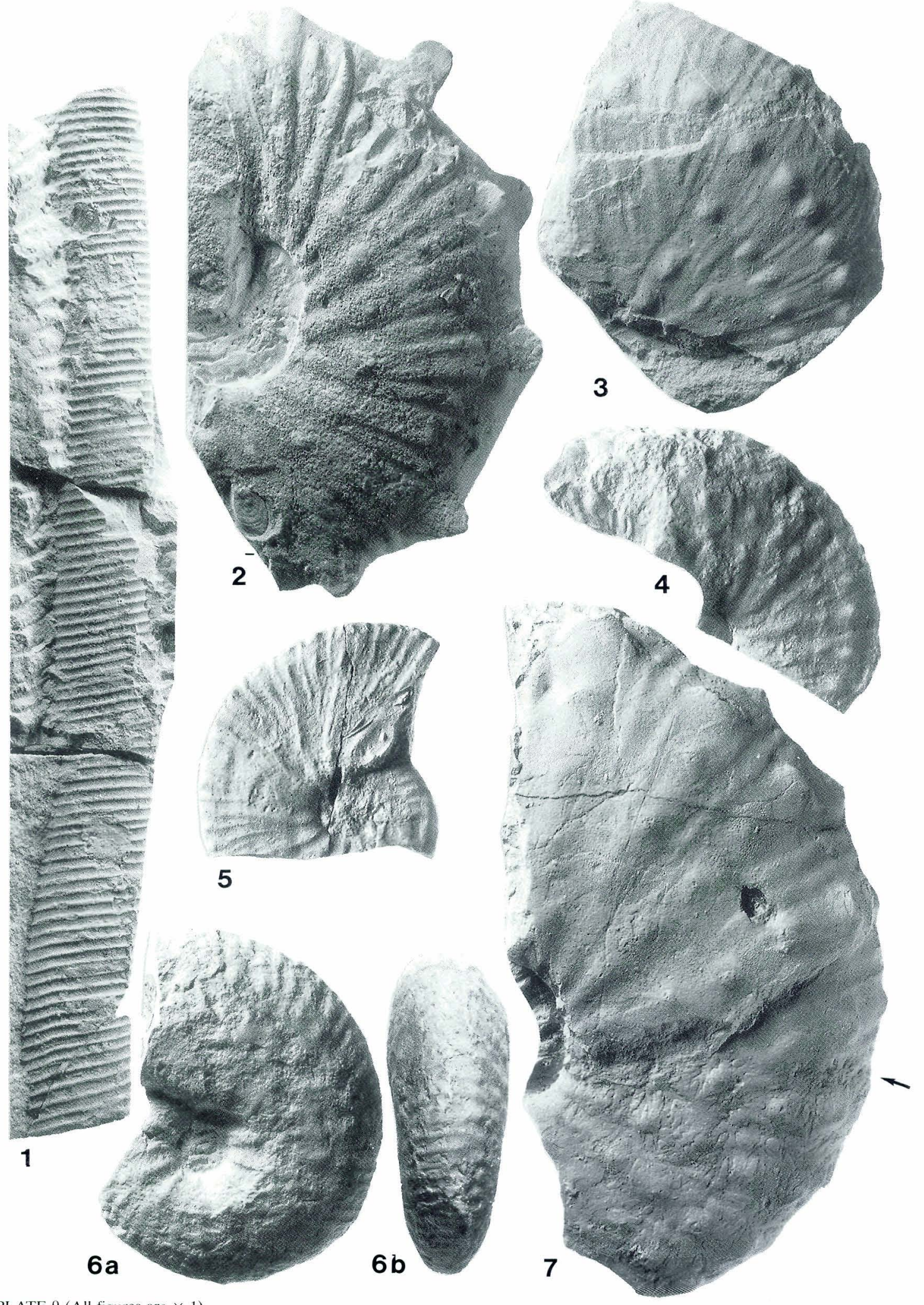

PLATE 9 (All figures are $\times 1$ ).

Fig. 1: Diplomoceras cylindraceum (Defrance, 1816), "Dania", MGUH 20123.

Fig. 2: Acanthoscaphites tridens (Kner, 1848). Part of body chamber with constricted aperture preserved. Hvidskud, Møns Klint, below the hardground, MGUH 20124.

Figs. 3-7: Acanthoscaphites varians (Lopuski, 1911), Rørdal, Ålborg. 3-5: No suture lines visible. 6: part of phragmocone. 7: outer Dart of nhragmocone and nart of hodv chamber 2 is MrIIH 201254 is MrI IH 20126 5 is MCIIH 70127. 6 is MGUH 20128, and 7 is 

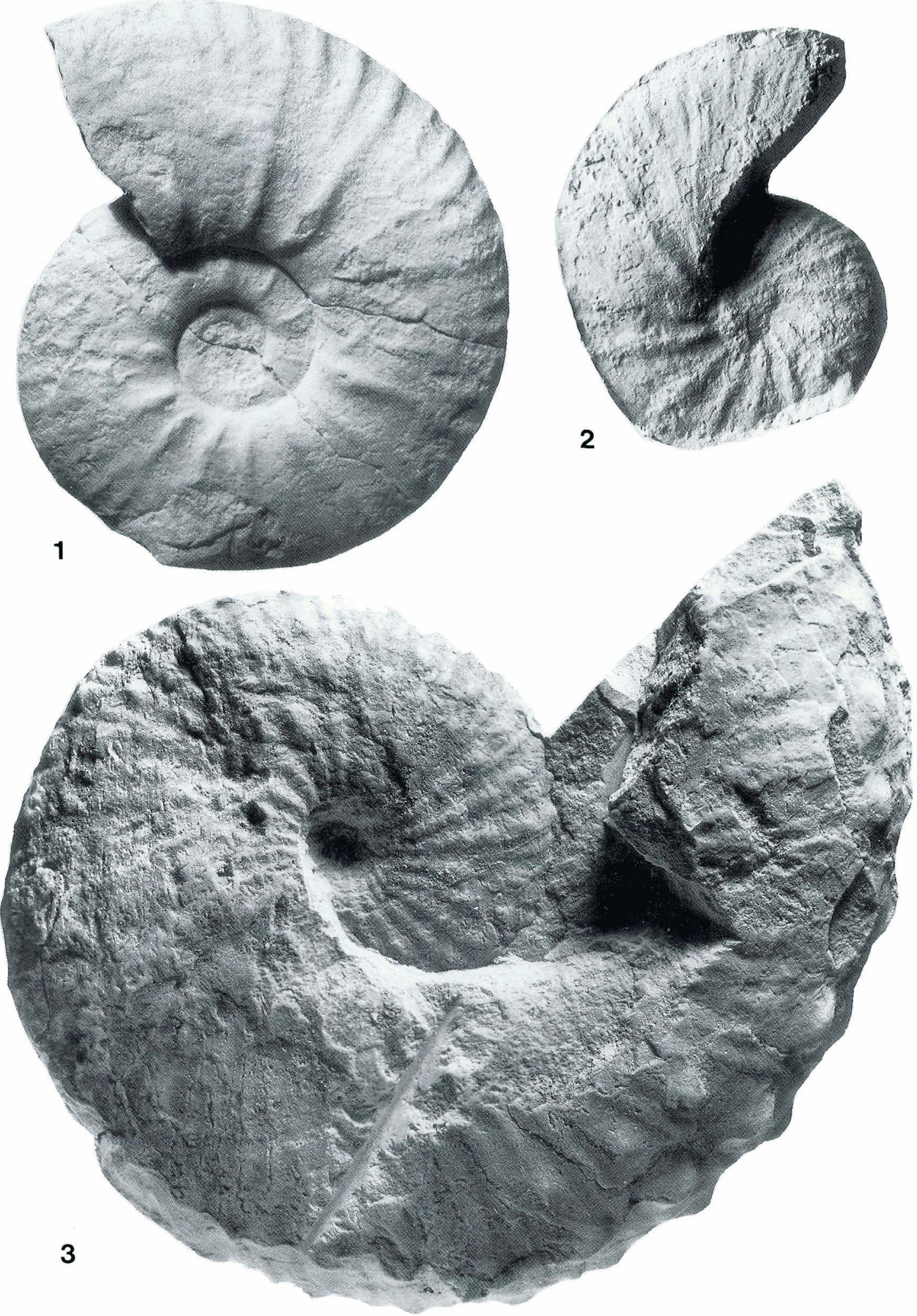

PLATE 10 (All figures are $\times 1$ ).

Fig. 1: Pachydiscus (Pachydiscus) neubergicus (von Hauer, 1858). Phragmocone found loose in drift, Lynge gravel pit, north of Copenhagen, MGUH 20131.

Figs. 2-3. Acanthoscaphites varians (Lopuski, 1911). 2: Cast of nearly complete microconch specimen with most of body chamber preserved, Rørdal, Ålborg, MGUH 20130. 3: Nearly complete macroconch specimen with most of body chamber preserved, Rørdal, Ålborg, MGUH 20129. 

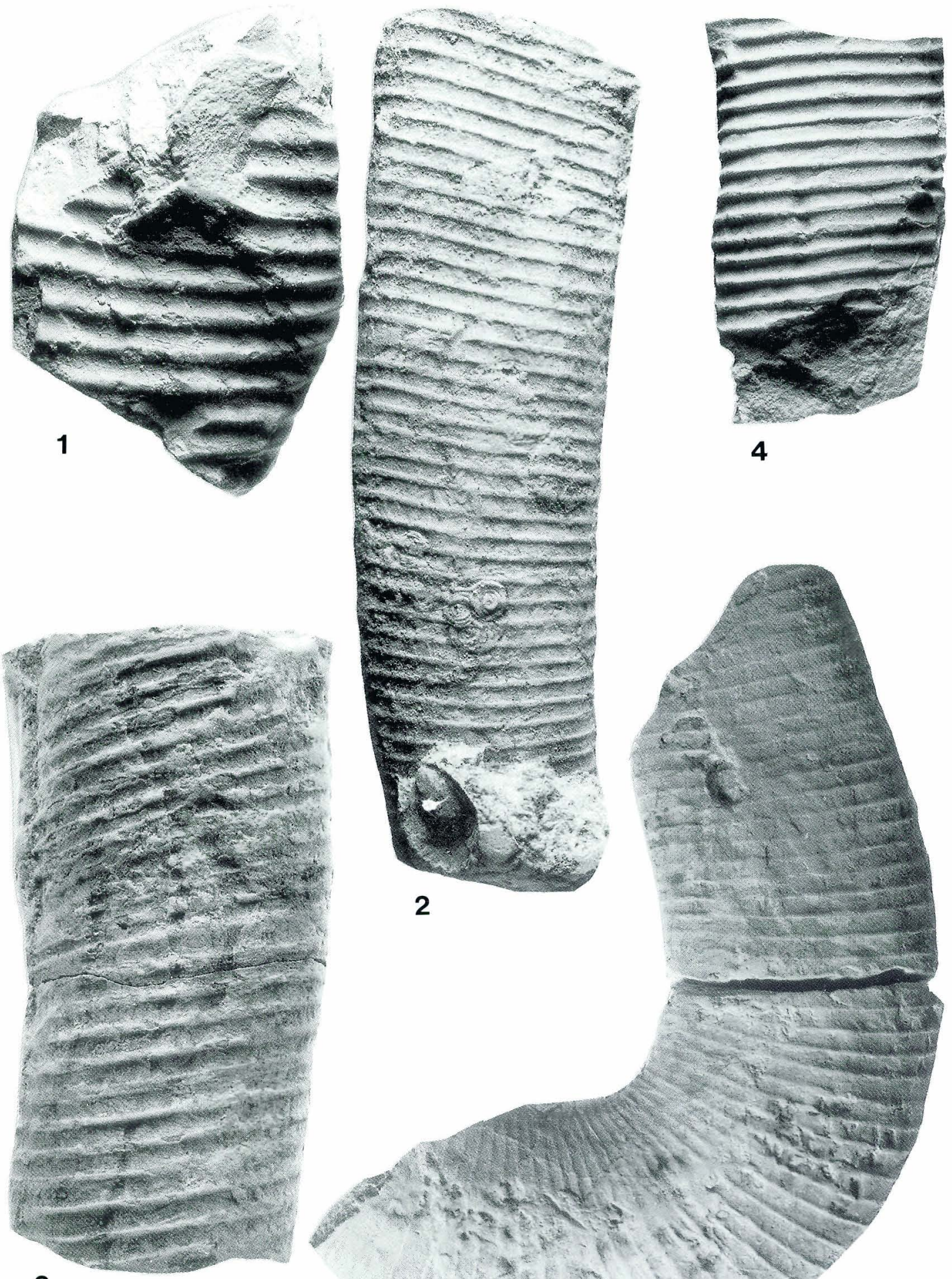

4

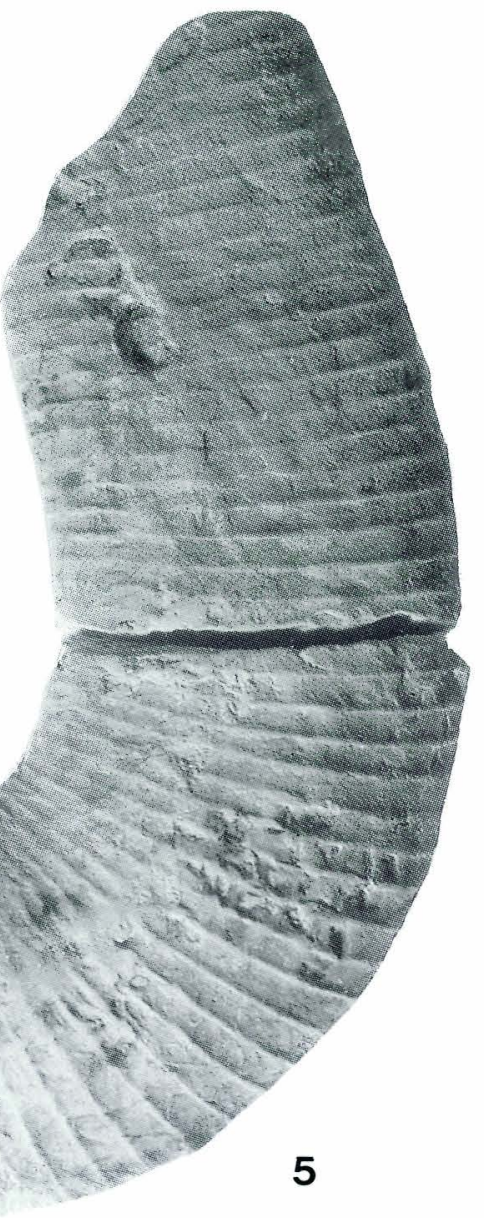

PLATE 11 (All figures are $\times 1$ ).

Figs. 1-5. Diplomoceras cylindraceum (Defrance, 1816). 1: Bjerre, MGUH 20132. 2-3: Ålborg, exact locality unknown, 2 is MGUH 20133, 3 is MGUH 20134. 4: "Dania", MGUH 20135. 5: Gudumlund, MGUH 20136. 


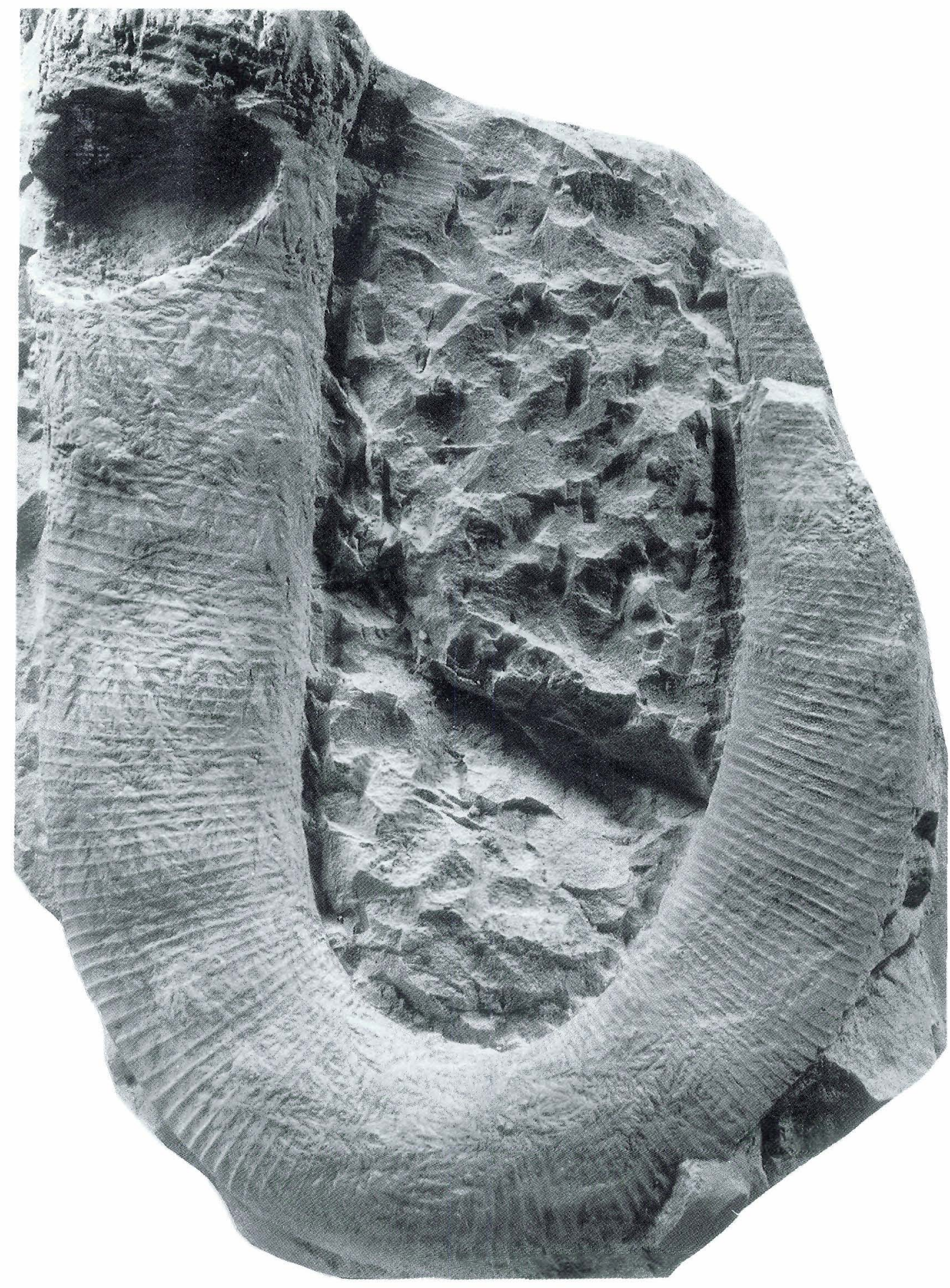

PLATE 12.

Diplomoceras cylindraceum (Defrance, 1816). Original of Ravn (1902, p. 249), from Frejlev, Ålborg, MGUH 20137. Reduced $\times$ 0.67 


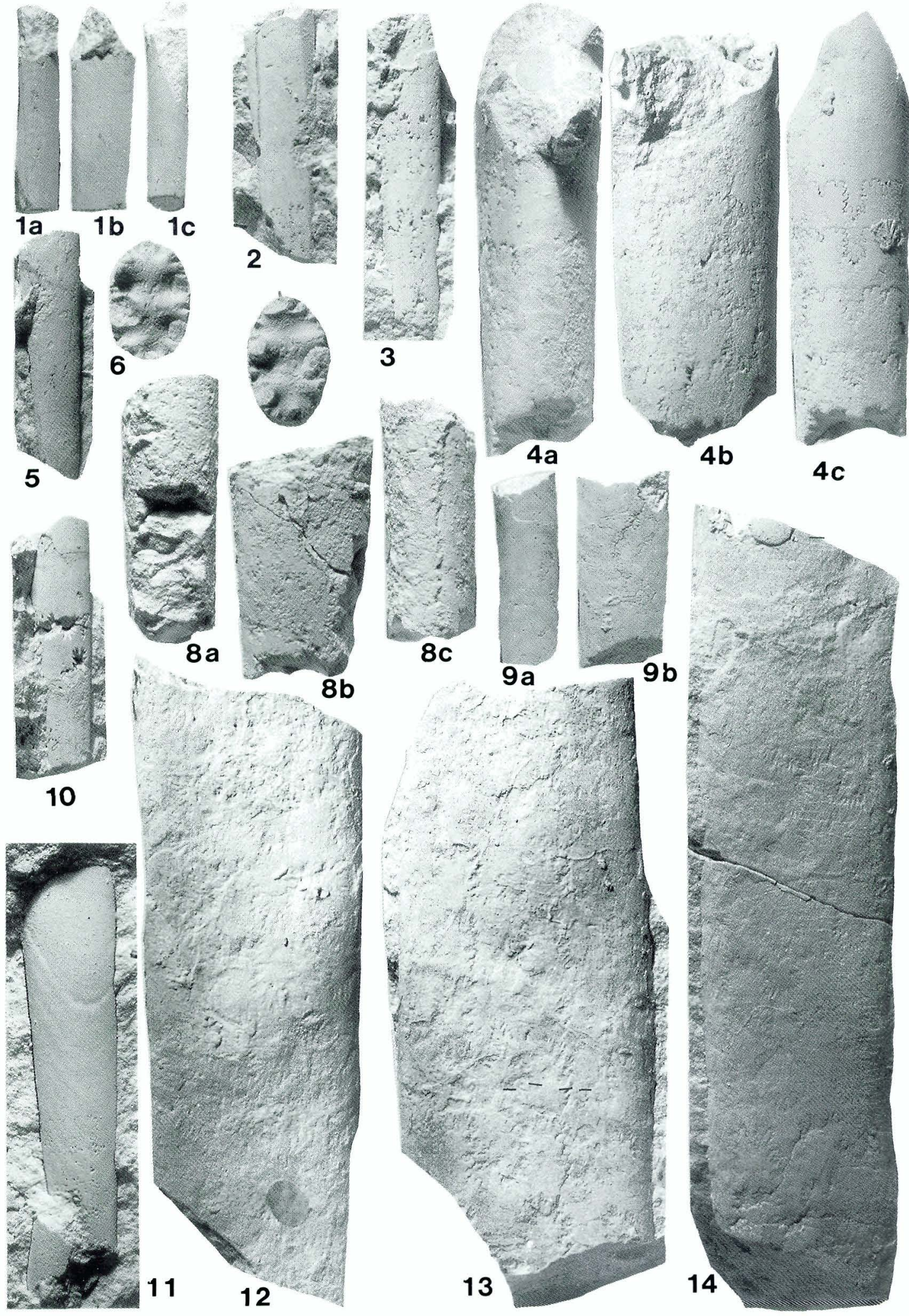

PLATE 13 (All figures are $\times 1$ ).

Figs. 1-11: Baculites vertebralis Lamarck, 1801. All specimens are from the top of the Maastrichtian hardground at Stevns Klint. MGUH 20138-20148.

Figs. 12-14: Baculites knorrianus Desmarest, 1817. All specimens are from Rørdal, Ålborg. MGUH 20149-20151. 


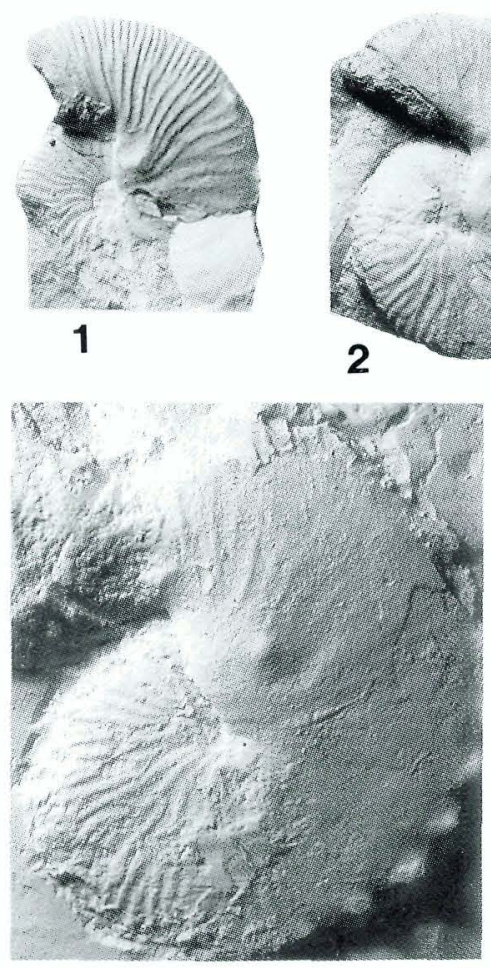

5

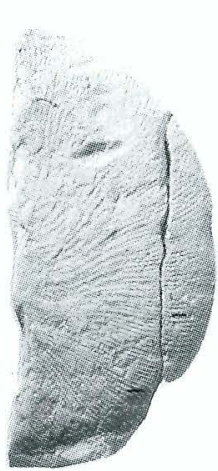

$10 a$

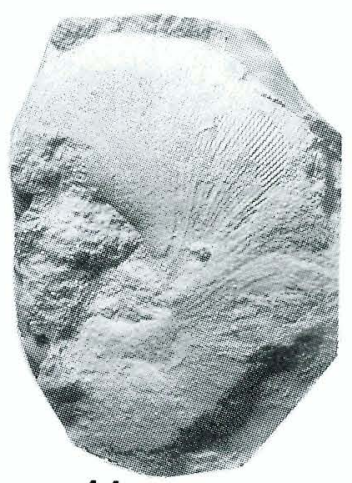

11

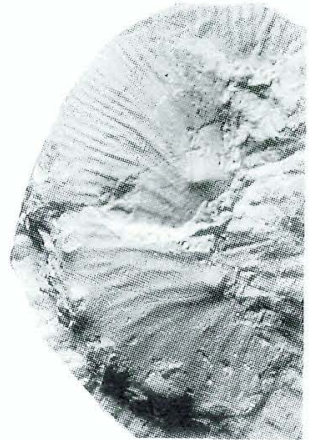

3

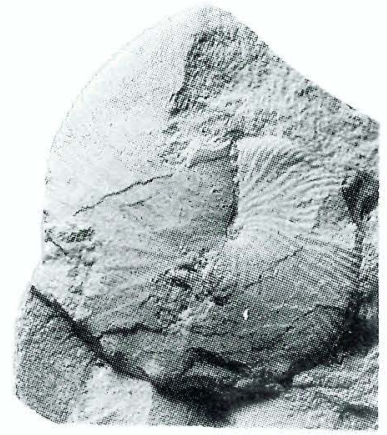

4

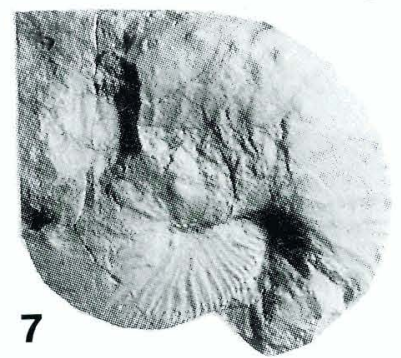

6
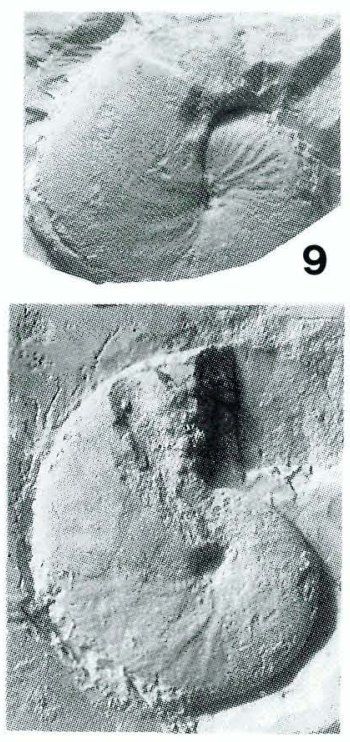

13
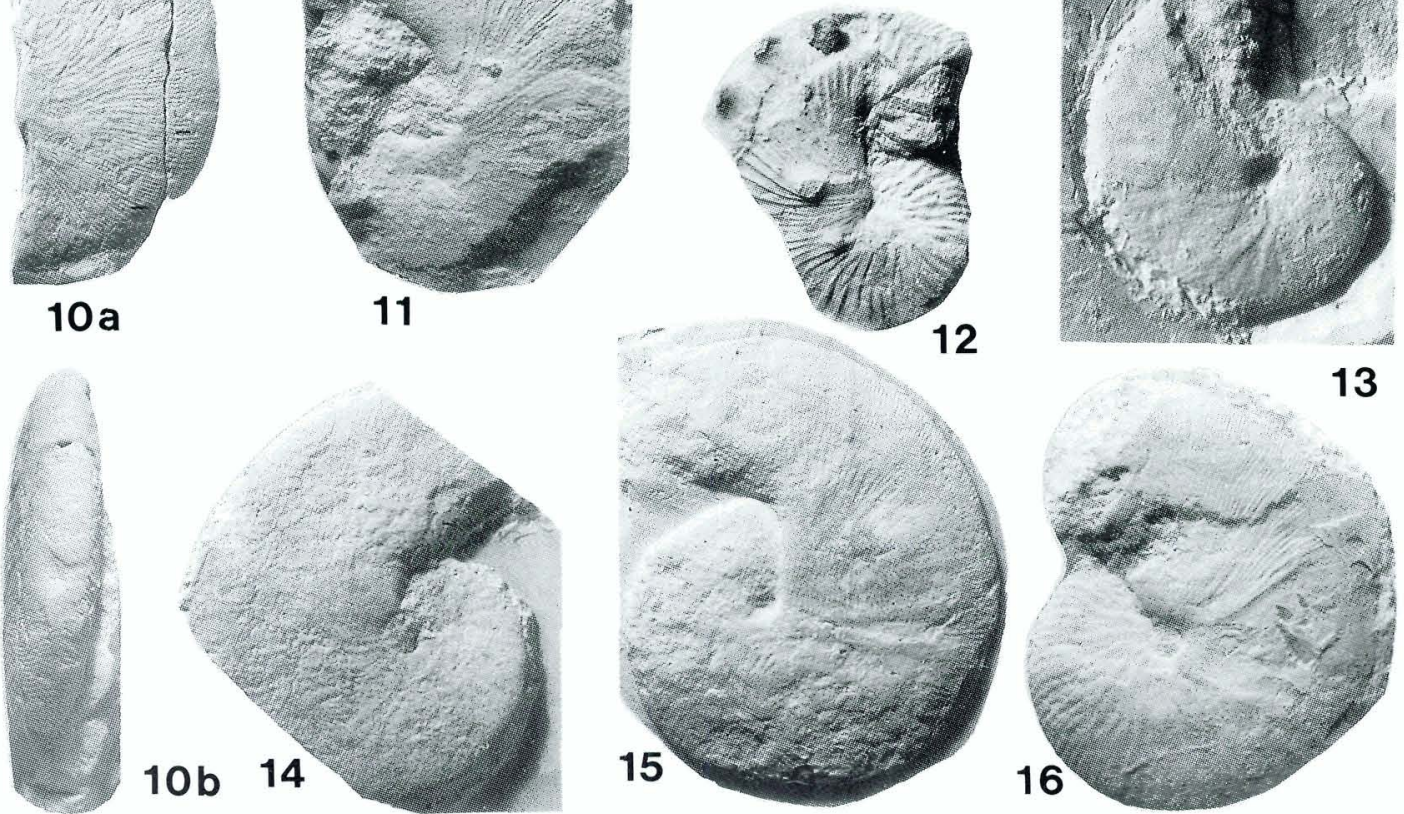

PLATE 14 (All figures are $\times 1$ )

Figs. 1-7, 12: Hoploscaphites constrictus (J. Sowerby, 1817). 1-4, 6-7, 12: Limhamn, Sweden. 5: Hov. 1 is MGUH 20152, 2 is MGUH 20153, 3 is MGUH 20154, 4 is MGUH 20155, 5 is MGUH 20155, 6 is MGUH 20157, 7 is MGUH 20158, and 12 is MGUH 20159. Figs. 8-11, 13-16: Hoploscaphites tenuistriatus (Kner, 1848). 8-10, 16: Ålborg; 11, 15: Rügen, German Federal Republic; 13: Hillerslev; 14: "Danmark". 8 is MGUH 20160, 9 is MGUH 20161, 10 is MGUH 20162, 11 is MGUH 20163, 13 is MGUH 20164, 14 is MGUH 20165, 15 is MGUH 20166, and 16 is MGUH 20157. 


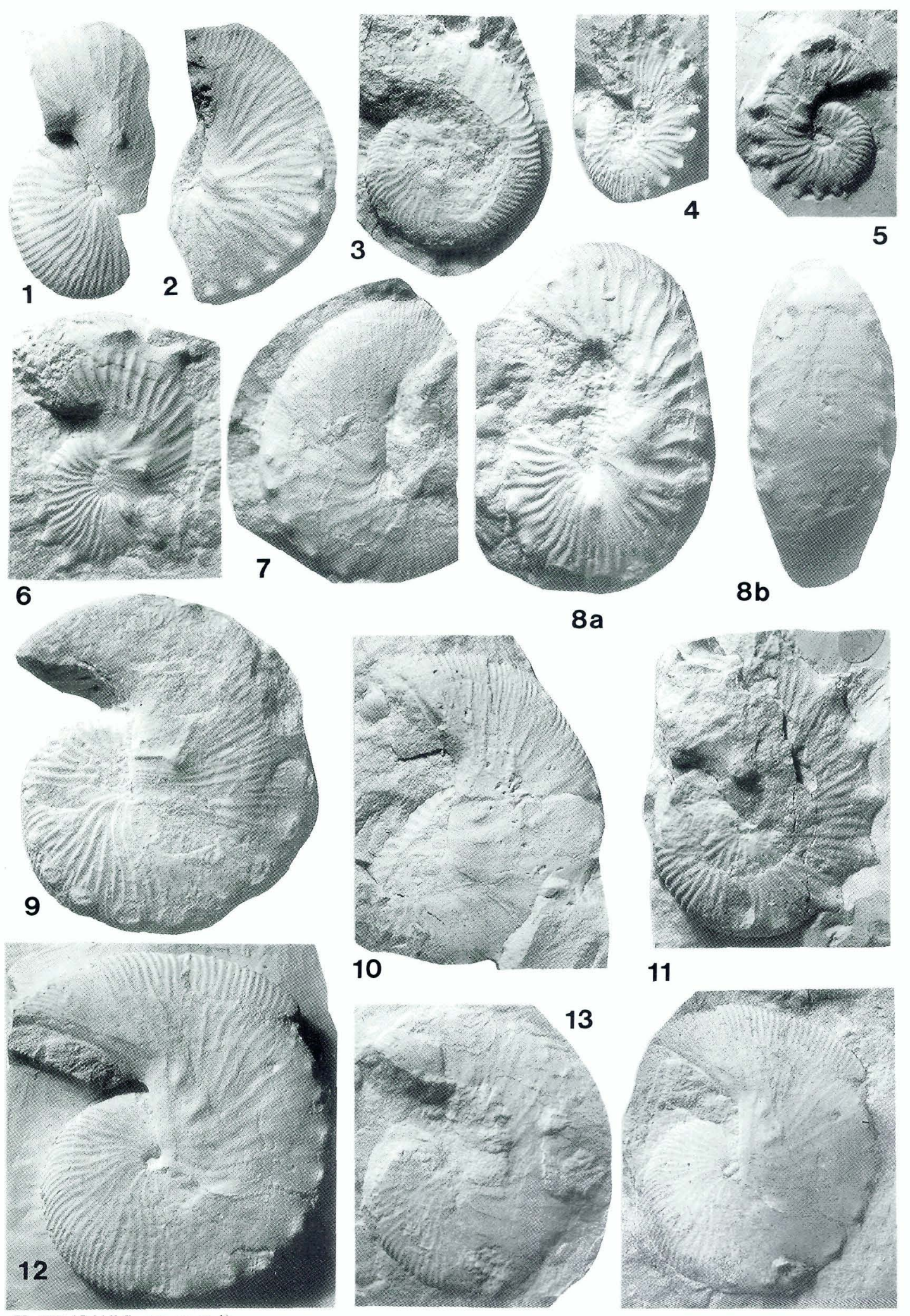

PLATE 15 (All figures are $\times 1$ ).

Figs. 1-14: Hoploscaphites constrictus (J. Sowerby, 1817). All specimens are from "Dania", MGUH 20168-20181. 

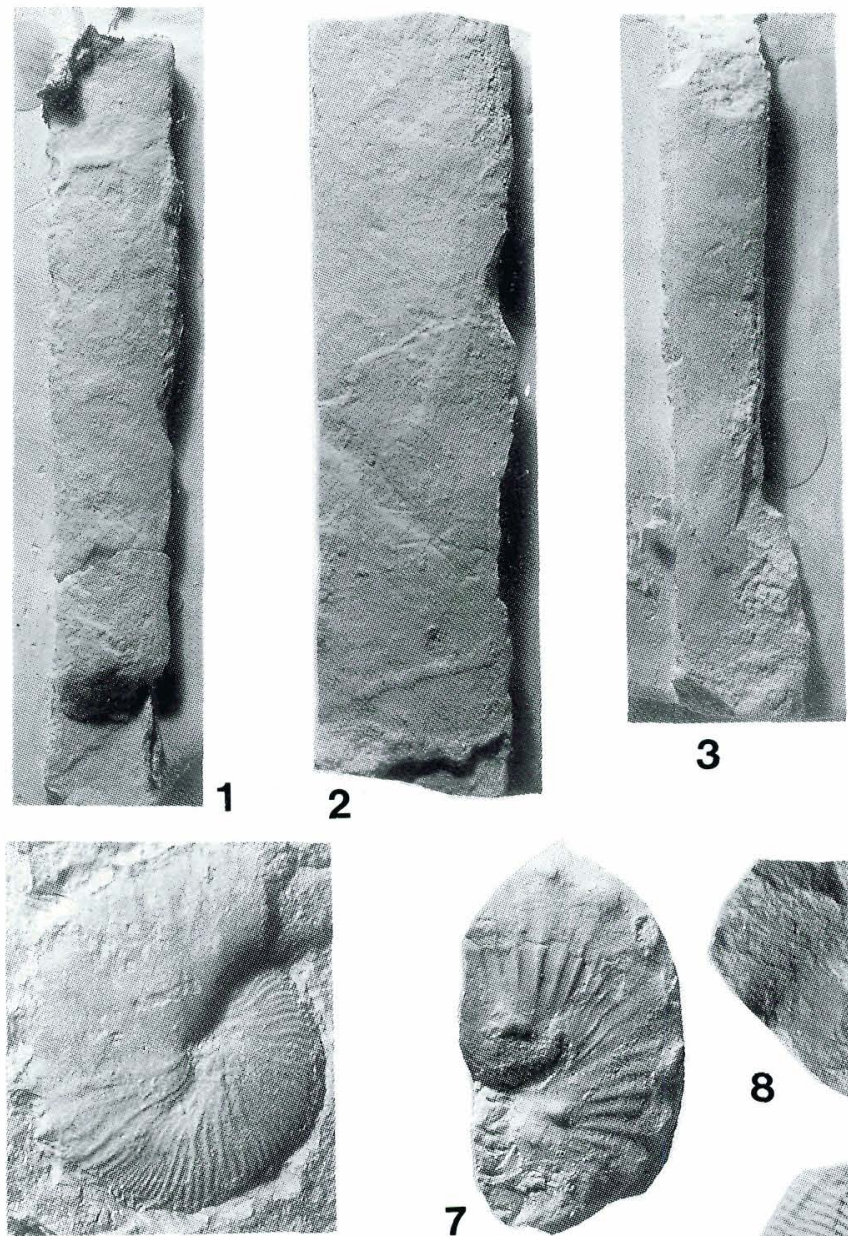

6

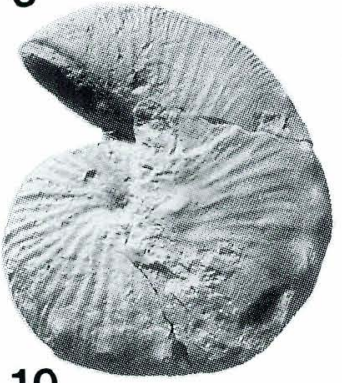

10

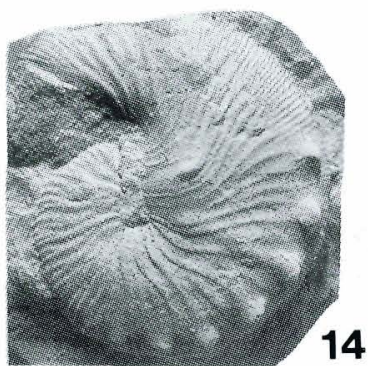

12

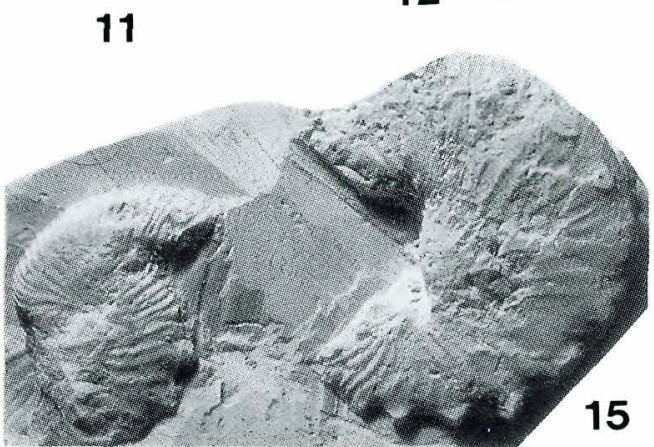

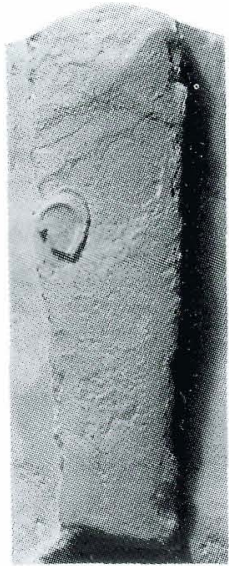

4

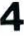

3
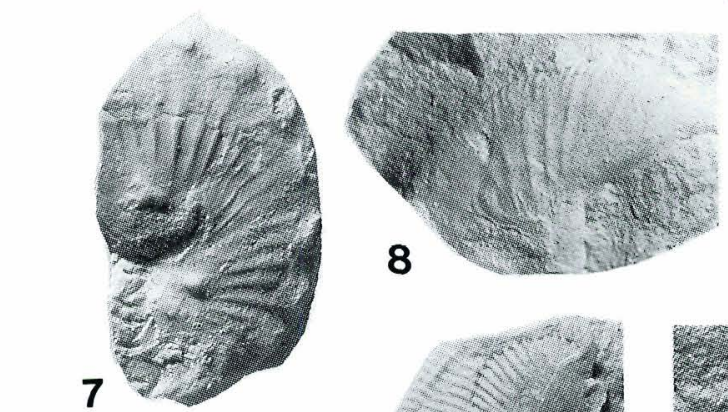

9

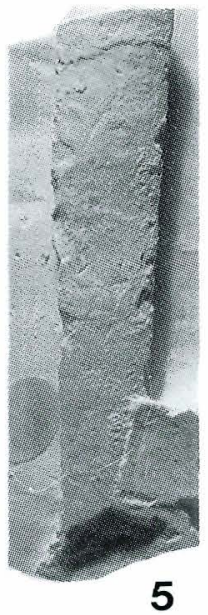

5

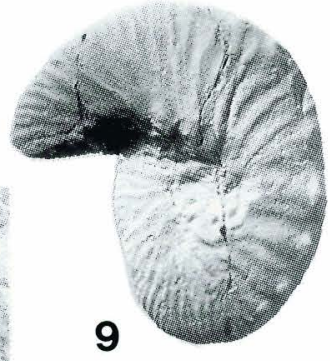

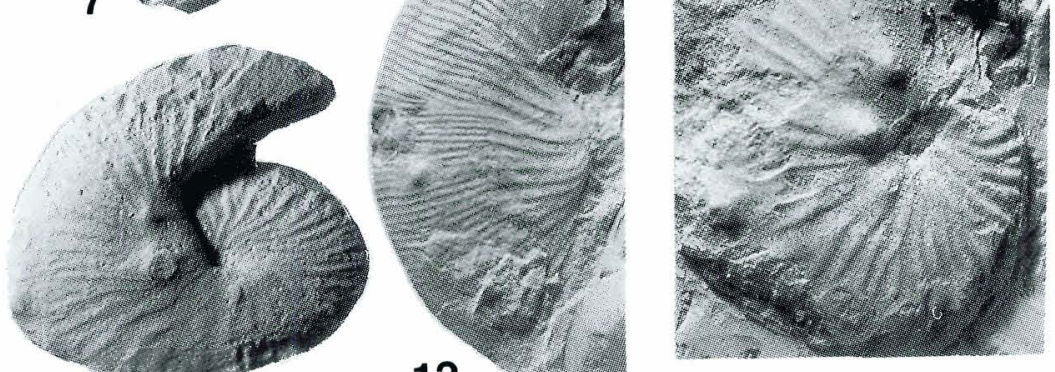

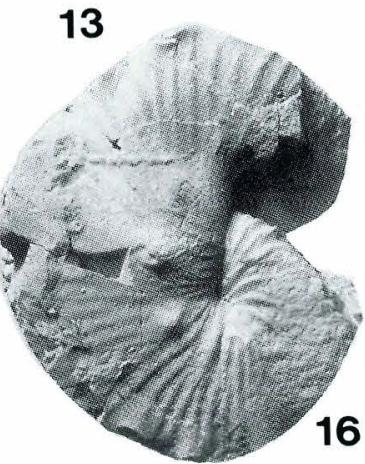

PLATE 16 (All figures are $\times 1$ )

Figs. 1-5: Baculites vertebralis Lamarck, 1801. All specimens are from Kjølby Gård. MGUH 20182-20186.

Figs. 6-16: Hoploscaphites constrictus (J. Sowerby, 1817). All specimens are from "Dania", MGUH 20187-20197. 


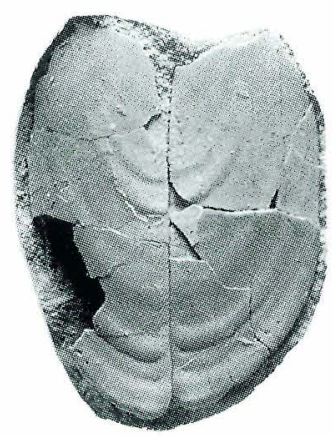

1

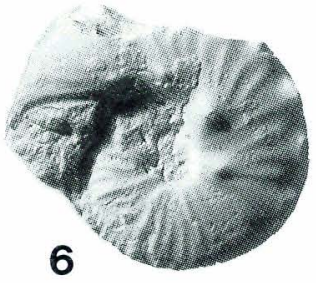

6

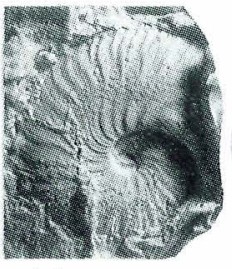

11

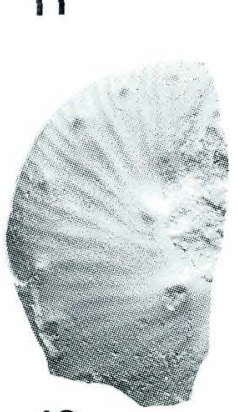

16

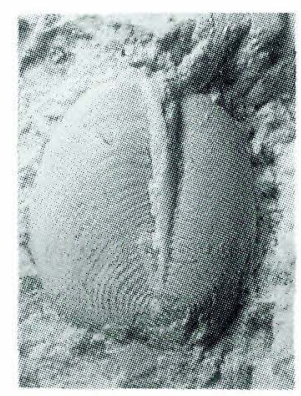

2

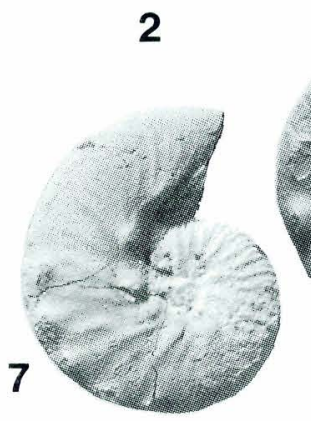

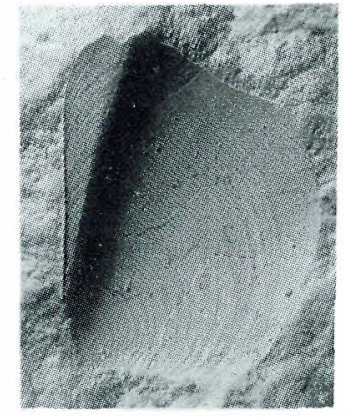

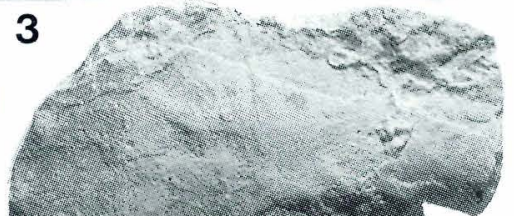

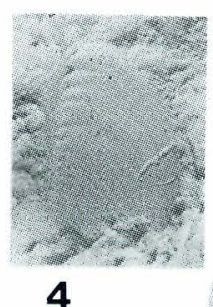

$5 a$

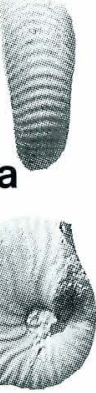

\section{$5 b$}

8
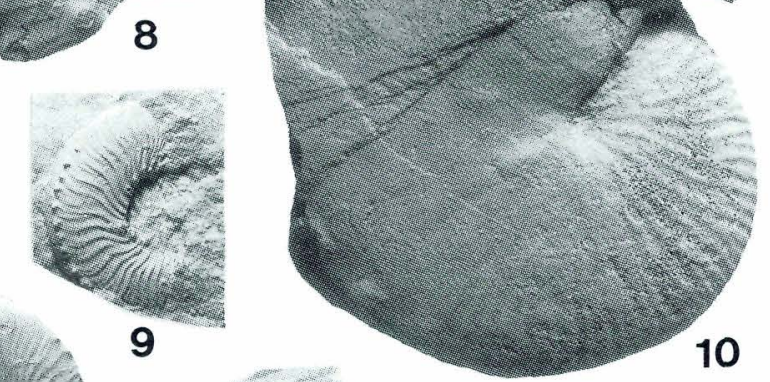

10
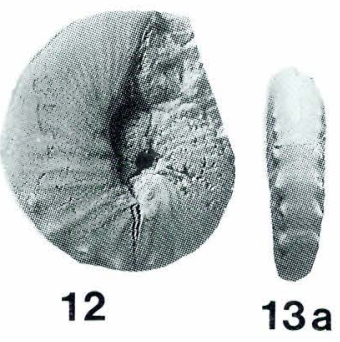

$13 b$

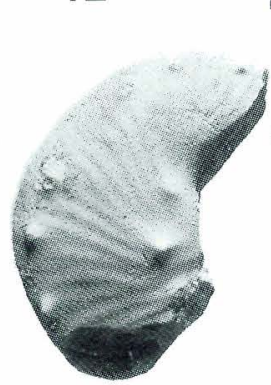

17

18
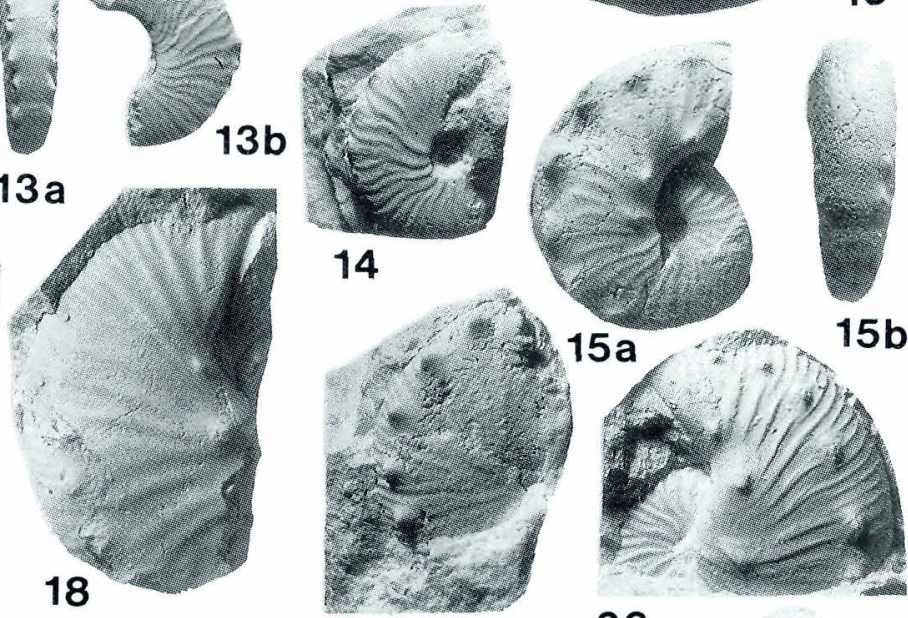

19
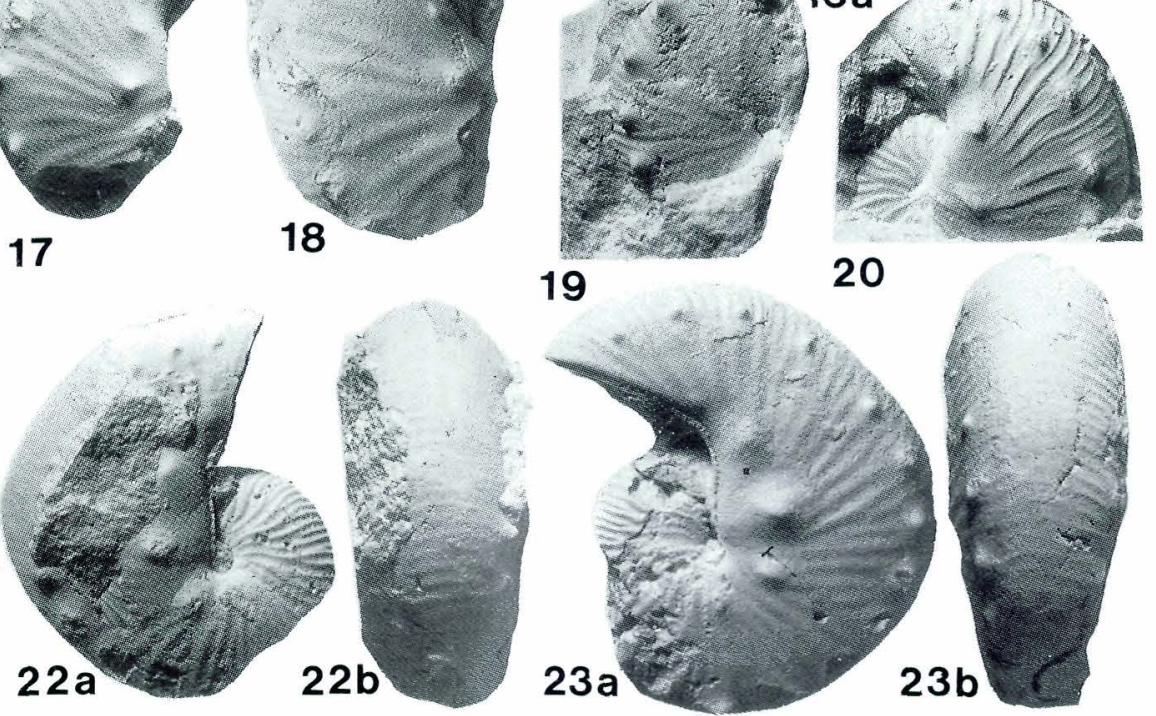

PLATE 17 (Figures 1, 5-23 are $\times 1$; figures $2-4$ are $\times 2$ ).

Fig. 1: Aptychus, perhaps of Pachydiscus, from Sigerslev chalk pit, Eskesti, Stevns Klint, MGUH 20198.

Figs. 2-4: Aptychus of Hoploscaphites, from Stevns Klint. 2 is MGUH 20199, 3 is MGUH 20200, and 3 is MGUH 20201.

Figs. 5-23: Hoploscaphites constrictus (J. Sowerby, 1817). 6-9, 11-23: top Maastrichtian hardground, 10: chalk below top Maastrichtian hardground, Stevns Klint. MGUH 20202-20220. 